\title{
THE POLITICAL ECONOMY OF BELIEFS: WHY FISCAL AND SOCIAL CONSERVATIVES/LIBERALS COME HAND-IN-HAND
}

\author{
DAniel L. Chen And Jo Thori Lind *
}

\begin{abstract}
Religious provision of social insurance may explain why fiscal and social conservatism align in the times and places that they do. We find evidence that religious groups with greater within-group charitable giving are more against the welfare state and more socially conservative. The alignment disappears when there is a state church and it reverses for members of a state church (social conservatives become fiscal liberals). This reversal is unlikely to be due to omitted variables: In two quasi-experiments, increases in church-state separation precede increases in the alignment between fiscal and social conservatism. We construct a model where elites increase church-state separation to create a constituency for lower taxes if religious voters exceed non-religious voters. Welfare state crowds out religious participation, leading to multiple steady states where some countries sustain high church-state separation, high religiosity, and low welfare state, and vice versa. This framework helps shed light on the changing nature of religious movements and the dynamic links between credit market access, church-state separation, and fundamentalism.
\end{abstract}

JEL classification: D31, D71, D72, D78, I38, Z12

Keywords: Voting, Religion, Ideology, Church-State Separation, Welfare State

*Daniel L. Chen, Chair of Law and Economics, ETH Zurich, chendan@ethz.ch; Jo Thori Lind, Department of Economics, University of Oslo. j.t.lind@econ.uio.no. Latest version at: http://nber.org/ dlchen/papers/PoliticalEconomy_of_Beliefs . pdf. We thank our dedicated research assistants for invaluable contributions to this project, numerous colleagues with helpful comments at Bergen, TU Dresden, Duke, University of Chicago, GMU, Harvard, Iowa State, Munich, NBER Summer Institute (Income Distribution and Macroeconomics), Ohio State, Oslo, Stockholm IIES, UCLA, UCSD, IUPUI, York, and Washington University. Work on this project was conducted while Daniel Chen received financial support from the European Research Council, Swiss National Science Foundation, National Institute for Child Health and Human Development, and UCLA International Institute; and while Jo Thori Lind received financial support from the Research Council of Norway through the Equality, Social Organization, and Performance (ESOP) Center (project number 179552 ). 
From abolition to woman suffrage to civil rights, the leaders of America's most successful liberal crusades have turned to the Bible to justify their causes. But the history of the religious left seems to stop in 1968, the starting point of a decades-long trend by which Democrats have become the secular party and the Republicans the religious party (Lizza 2005).

\section{INTRODUCTION}

Can market forces shape normative commitments? From financial crises to international trade ${ }^{1}$, litigation funding to industry-physician relationships ${ }^{2}$, competition to gender relationships ${ }^{3}$, economic incentives are linked to a wide range of normative commitments. This paper links within a unified framework why some countries separate church and state (Barro and McCleary 2005) and why fiscal and social conservatives and fiscal and social liberals appear hand-in-hand in the times and places that they do. ${ }^{4}$ Today, many argue that depending on the welfare state is the same as worshipping the government as if it were God. ${ }^{5}$ Welfare support decreases in the U.S. while fundamentalism increases with religious attendance (Figure 1). ${ }^{6,7,8}$

Figure 1: Welfare attitudes and Fundamentalism in the U.S.

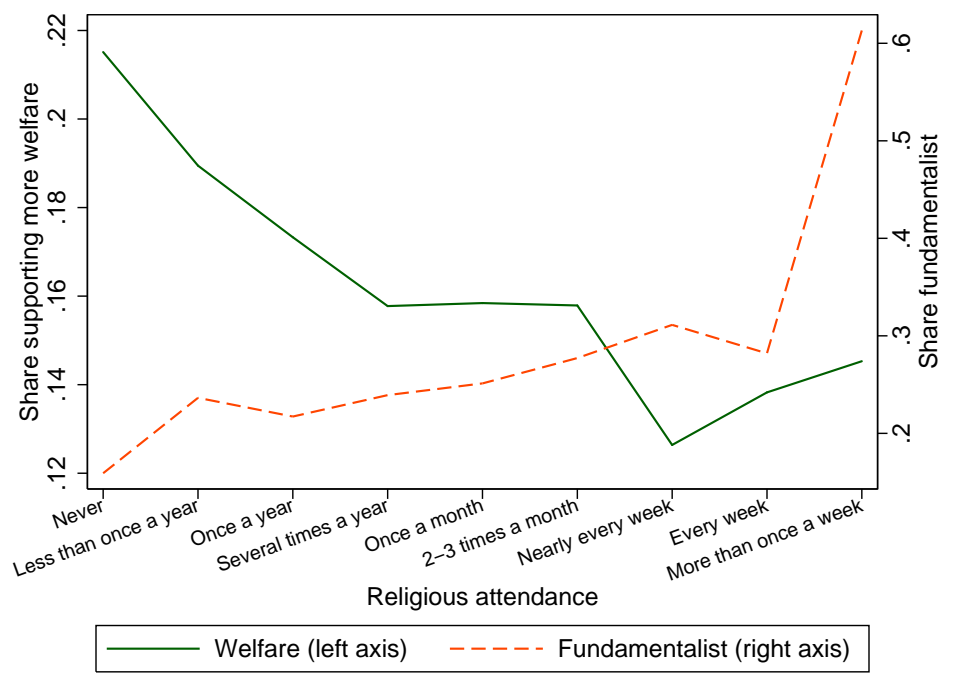

Notes: Data are from the General Social Survey cumulative file, 1972-2012. Respondents are classified as supporting welfare if they answer that we are spending too little on welfare, and as fundamentalist if they belong to a denomination classified as fundamentalist. Sample is the white population.

No obvious theory explains the emphasis on individual responsibility by contemporary religious

\footnotetext{
${ }^{1}$ Chen (2010); Chen and Givati (2014)

${ }^{2}$ Chen (2014); Chen et al. (2014b)

${ }^{3}$ Chen (2012); Chen (2004) Layman (2001) for general discussions of cultural and religious divides.

${ }^{5}$ Fernandez et al. (2003) and Hornberger (1993). among African Americans cf Appendix Table VIII.

${ }^{7} 33 \%$ of Americans are fundamentalist in the General Social Survey.

${ }^{8}$ The pattern holds for other fiscal attitudes. See Appendix Figure 1.
}

${ }^{4}$ See Converse (1964) and Poole and Rosenthal (1991), (1997) on U.S. congressional voting; Gill and Lundsgaarde (2004), Scheve and Stasavage (2006), and Cavanaugh (2005) on cross-country evidence; and Fiorina et al. (2011) and

${ }^{6}$ In all subsequent analyses, we include all races and control for race. Many black churches receive government funding to provide services to their neighborhoods' poorest residents (Owens 2007) and the pattern is indeed weaker 
groups at the expense of the welfare state. ${ }^{9}$ At first glance, such an alignment is puzzling since a philosophy against government intervention espoused by the Republican party on fiscal matters could be a good fit with a similar position on issues of personal choice such as abortion. Furthermore, this alignment has not always existed. The Social Gospel movement of the early 1900s (Fogel 2000) and the Christian Democratic party in European countries are examples of alignment along the other diagonal of the matrix of fiscal and social attitudes.

We hypothesize that religious provision of social insurance ${ }^{10}$ explains when religious groups are against welfare: when it competes against their constituency. We build a unified explanation for three puzzles: (1) why fiscal and social conservatism align together in most countries; (2) why fiscal and social conservatism did not align together in the past or in some countries today; (3) why some countries sustain high religiosity, high church-state separation, and low welfare state while others sustain low religiosity, low church-state separation, and high welfare state. ${ }^{11}$ Separation between church and state plays a key role. Welfare is not competitive against religious groups when government funding can be distributed to religious groups.

Our model endogenizes church state separation using a second ingredient: religiosity decreases with size of welfare state. ${ }^{12}$ Elites, who desire low taxes, separate church and state when the relative share of religious constituencies is large. Separation of church and state reduces welfare support by religious constituencies. Reductions in the welfare state induce marginal members seeking insurance to become more religious, creating a positive feedback. When the relative share of non-religious constituencies is large, elites prefer a state church to reduce the tax preferences of the secular left, but a smaller welfare state would induce marginal members seeking insurance to become more religious, creating a negative feedback. These two forces stabilize countries with low initial religious weight at low religiosity, low church-state separation, and high welfare state.

Several empirical regularities are consistent with this theory. Using a variety of data sources on individual attitudes, we show that fiscal and social conservatism and liberalism come hand-inhand at the individual level within countries, not just congressionally or across countries; ${ }^{13}$ social conservatism and fiscal conservatism are positively correlated with religious attendance; and religious groups with greater within-group charitable giving are more against the welfare state and more socially conservative. We also show that the relationship between religious attendance and fiscal conservatism disappears in countries with a state church and the alignment reverses, religious attendance predicts increasing support for welfare, if the individual is a member of the state church.

We use several quasi-experiments to show that this reversal is unlikely to be driven by omitted environmental variables: increases in church-state separation in the U.S. Supreme Court precede increases in the alignment between fiscal and social conservatism among U.S. voters; in a panel

\footnotetext{
${ }^{9}$ Scheve and Stasavage (2006) reject explanations involving denominational differences, altruism, differences in the making of inferences, issue-bundling, and spurious correlation. Glaeser et al. (2005) build a model to explain why religion is salient in politics but not why Republicans and Democrats divide along religious issues the way that they do. Jost et al. (2003) proposes that uncertainty aversion explains why fiscal and social conservatism come together but do not explain why they do not come together in some countries or time periods.

${ }^{10}$ For theory of religious insurance, see Iannaccone (1992) and Berman (2000); for evidence, see Dehejia et al. (2005) and Chen (2006), (2010), which analyze $\Delta$ Outcome $=\Delta$ Income + Religion $+\Delta$ Income $*$ Religion (Dehejia, et.al run this specification in the U.S. while Chen analyzes this in Indonesia).

${ }^{11}$ For the negative correlation between religious attendance and having a state church, see Finke and Stark (1992), Iannaccone (1998), and Barro and McCleary (2005); for the negative correlation between religiosity and size of welfare state, see Gill and Lundsgaarde (2004), Scheve and Stasavage (2006), and Cavanaugh (2005).

${ }^{12}$ Gruber and Hungerman (2007), Hungerman (2005), Gill and Lundsgaarde (2004), and Cnaan et al. (2002) document that government welfare crowds out church participation and charitable provision.

${ }^{13}$ For uni-dimensionality of U.S. congressional voting: Converse (1964), Poole and Rosenthal (1991), and Keith T. Poole (1997); for cross-country patterns: Gill and Lundsgaarde (2004), Scheve and Stasavage (2006), and Cavanaugh (2005).
} 
of Norwegian and Swedish voters, Christian conservatives become more fiscally conservative after the Swedish separation of church and state in 2000; and random variation in Establishment Clause jurisprudence (e.g., disallowing prayer or religious meetings in public schools) arising from the random assignment of judges in the U.S. Circuit Courts shows that fundamentalists become more likely to identify strongly as Republicans after exogenous increases in church-state separation.

A third ingredient - the development of credit markets - explains when religious movements changed from religious groups that once led the welfare movement around the world to right-wing religious factions interested in dismantling the welfare state. One hallmark of modern society is the establishment of credit markets (Hirschman 1982). Prior work establishes that credit markets reduce the need for religious provision of social insurance (Chen 2006; Chen 2010; and Glaeser and Scheinkman 1998). We hypothesize that as credit markets develop, elites are the first to gain access to alternative forms of social insurance. In countries with high religiosity like the U.S., elites increase church-state separation, ${ }^{14}$ thereby creating right-wing religious coalitions, who want less welfare, which in turn generates a self-sustaining cycle of high religiosity, high church-state separation, and low welfare provision. In many European countries with low initial religiosity, however, elites never increased church-state separation, which generates a stable steady state with low religiosity, low church-state separation, and high welfare provision.

Temporary shifts in any of these factors can cause countries to permanently shift from one steady state to another. One implication for international law is that economic sanctions may increase theocratic tendencies in war-torn developing countries if elites are restricted from international capital markets and lose access to alternative social insurance. In this case, the story reverses: if religious share of population is high, elites decrease church-state separation in order to increase the constituency for a high degree of government-cum-religious insurance. This perspective sheds light the dynamics of credit market access, theocracy, and fundamentalism in developing and reconstructing war-torn countries.

Our paper also contributes to several literatures: the political economy of redistribution (Romer 1975; Meltzer and Richard 1983; Roemer 1998) and social insurance (Moene and Wallerstein 2001, 2003), the role of elites (Acemoglu and Robinson 2000) and demographic groups (Edlund and Pande 2002) in redistribution, ${ }^{15}$ and a theoretical literature showing that political positions eventually map along a single axis (DeMarzo et al. 2003) (whereas we ask why particular positions - e.g., attitudes towards abortion and taxes - map to similar coordinates on that axis). The remainder of the paper is organized as follows: Section 2 presents our model. Section 3 discusses the data. Sections 4 through 7 present the empirical evidence and Section 8 concludes.

\section{MODEL}

\subsection{Social Insurance in Religious Groups}

The degree to which charity and insurance occurs within religious groups has been noted in surveys (Iannaccone 1992), theoretical models (Berman 2000), and empirical work (Dehejia et al. 2005; Chen 2006, 2010). Sociologists and anthropologists have documented that frequent churchgoers report larger social networks, more contact with network members, more types of social support received (Ellison and K.George 1994), and meaningful levels of bidirectional material support within religious communities (Maton 1987). Approximately half of all philanthropic donations from individuals in the U.S. go to religious organizations. By 2003, financial giving to religious organizations amounted to $\$ 84$ billion annually (Cadge and Wuthnow 2006 citing U.S. Statistical Abstract 2004).

\footnotetext{
${ }^{14}$ Feldman (2005) and Hamburger (2002) document that separation of church and state was not read into the U.S. Constitution until the twentieth century.

${ }^{15}$ Lind (2005) provides a literature review on the relationship between pre-tax inequality and redistribution.
} 
Up to 20-25 percent of church expenditures are for charitable purposes, exceeding $\$ 24$ billion in philanthropic services annually (Biddle 1992; Gruber and Hungerman 2007).

The degree of mutual insurance in religious sects arguably exceeds that of traditional Indian villages studied by Townsend (1994) (Berman 2000). Mutual insurance can be in-kind. In some religious groups, no sick members are without visitors and that if members donate, they can receive free services for burial, assistance for new babies or the elderly in their household, and interest-free loans from hundreds to thousands of dollars (Landau 1993). During the 1997 Indonesian financial crisis, religious school fees were waived and individuals seeking employment were matched to employers seeking workers through public announcements at religious meetings; $70 \%$ of income shocks during the crisis were smoothed by religious institutions (Chen 2006). In the U.S., religious participation smooths $35 \%$ of income shocks in Townsend-style insurance tests $(\Delta$ Outcome $=\Delta$ Income + Religion $+\Delta$ Income $*$ Religion $)$ (Dehejia et al. 2005).

Social insurance is not limited to those who participate ex ante. Religious organizations help individuals after they experience negative income shocks possibly due to the fact that social sanctions in religion overcome the individual rationality constraints that would otherwise prevent ex post insurance groups from forming (Chen 2006). Even marginal individuals who join ex post benefit the group's social insurance in subsequent periods. Economists have noted that social pressure and individual guilt, nurtured through religious and family education, can work as enforcement mechanisms for social insurance (Fafchamps 2004; Ellsworth 1989). A strong form of social sanction toward those who belong to other religious organizations or are less religiously intense, provided in the doctrine of many religions facilitates religion's function as ex post insurance by encouraging people who receive positive shocks to participate. Experimentally induced group identity increases the degree of altruism toward in-group members relative to out-group members (Chen and Li 2009). Mutual insurance groups without such strong social sanctions would be less robust to economic volatility; no other social organization provided ex-post insurance during the Indonesian financial crisis (Chen 2006).

More conservative groups arguably have stronger social sanctions to make mutual insurance more self-sustaining. Church involvement among evangelical Protestants is associated mainly with volunteering within the congregation, while mainline Protestants volunteer with a wider variety of community organizations (Wuthnow 2004). In one national survey of working Americans, $4 \%$ claimed to have received financial help from a religious organization within the past year. $80 \%$ of these recipients were themselves church or synagogue members (compared to $56 \%$ of non-recipients) and $61 \%$ belonged to religious fellowship groups (compared to $18 \%$ among non-recipients). The recipients were disproportionately those who had been laid off from work or experienced pay cuts and had trouble paying their bills (Wuthnow 1994).

Using the General Social Survey (GSS), we document that across all religions, higher attendance is correlated with responding to the question, "If you were ill, how much would people in your congregation help you out?," with the answer, "a great deal," as opposed to "some," "a little," or "none" (Appendix Table: XI, Column 1). The coefficient in Column (1) indicates that moving eight categories of religious attendance from "never attend" to "several times a week" would increase the probability of receiving a great deal of help by over 60 percentage points. But, members of more conservative denominations, such as Evangelical Protestants, are significantly more likely to receive a great deal of help if ill (57 percent would), than are members of less conservative denominations, such as Jews (only 33 percentage would). 


\subsection{Basic Set Up}

We model religious provision and government provision of social insurance as substitutes to explain why fiscal and social conservatism align together in most countries; why this alignment reverses for members of a state church; and why multiple steady states sustain high religiosity, high church-state separation, and low welfare state and vice versa.

In our model, agents would like to insure themselves against income shocks. They make an insurance decision today in anticipation of income in the next period that is distributed with mean $\mu$ and variance $\sigma^{2}$, and they prefer higher expected value and lower variance in income: ${ }^{16}$

$$
\mu-\frac{1}{2} \sigma^{2}
$$

The model's time sequence is as follows: at time $t=0$, both the level of religiosity and the level of church-state separation are set (church-state separation will be endogenized later). At time $t=1$, the agents choose the level of taxes for income realizations at time $t=2$.

\subsection{Taxes}

Consider agents' choice of taxes first. Agents vote for a level of taxation $(\tau)$ that provides a form of insurance. With taxation, income next period will be: $(1-\tau) y+R(\tau) \mu$. This expression has the state collecting $\tau$, a portion of income from each citizen, and then giving back the average of collected incomes, $\mu$. In addition, the function $R(\tau)$ reflects deadweight losses associated with taxation (e.g., due to the state keeping a portion of the taxes).

When $R(\tau)=\tau$ there are no deadweight losses, so agents choose perfect insurance $(\tau=1)$ - people with high income will give more in taxes and get back less $(\mu)$, while agents with low income will give less in taxes and get back more. With distortions, the agents balance insurance considerations against the distortive effects of taxation. To see this, assume a standard concave function: $R(0)=0, R^{\prime}>0, R^{\prime \prime}<0$, and $R^{\prime}(0) \leq 1$. The assumptions capture the fact that deadweight loss to taxes is 0 when taxes are 0 and increases with taxation. ${ }^{17}$

The distribution of income with taxation will have mean $(1-\tau)+R(\tau) \mu$ and variance $(1-\tau)^{2} \sigma^{2}$. Thus, in choosing the tax rate, agents will maximize:

$$
[(1-\tau)+R(\tau)] \mu-\frac{1}{2}(1-\tau)^{2} \sigma^{2}
$$

The FOC yields:

$$
\left[-1+R^{\prime}(\tau)\right] \mu+(1-\tau) \sigma^{2}=0
$$

or,

$$
\frac{\mu}{\sigma^{2}}=\frac{1-\tau}{1-R^{\prime}(\tau)}
$$

\footnotetext{
${ }^{16}$ This could be seen as a reduced form of agents with CARA preferences and normally distributed shocks or agents with quadratic preferences, and is also in line with standard portfolio theory.

${ }^{17}$ Note that deadweight loss is never so high that less is available for redistribution when there are higher taxes.
} 
The right-hand side is a decreasing function of $\tau$, so the agent balances the inherent randomness of income next period with the distortionary effects of taxation: the higher the income variation next period (bigger $\sigma^{2}$ relative to $\mu$ ), the higher the agent's preferred tax rate.

The equation above can be rewritten as:

$$
(1-\tau) \sigma^{2}=\left(1-R^{\prime}(\tau)\right) \mu
$$

which provides the intuition for the basic setup. The left-hand side is the marginal benefit of increasing taxes: with higher taxes, the agent reduces the variance of income shocks. The righthand side is the marginal cost of taxes: it is the deadweight loss that comes from taxation. At the optimum, the agent equates marginal benefit to marginal cost.

\subsection{Religiosity}

Now suppose the agent chooses taxation, having already observed their level of religiosity. Religiosity also provides a source of insurance of in-kind or material benefits through the church. It works much like government taxation: agents give donations $d$ as a portion of their income, which the church redistributes back as $P(d) \mu$, where the function $P(d)$ has similar first- and second-order derivative properties as the government's tax revenue function. The value $d$ can be interpreted in two ways. $d$ is the level of insurance that the agents insure through the church and it is also an indicator of their level of religiosity (the higher the level of religiosity, the more the agents are willing to donate to the church, and the church rewards the more devoted with higher payments). Then, with both religiosity and taxation, the agents' income next period will be: $(1-\tau-d) y+R(\tau) \mu+P(d) \mu$, which means that the agents will maximize at time $t=1$ :

$$
[(1-\tau-d)+R(\tau)+P(d)] \mu-\frac{1}{2}(1-\tau-d)^{2} \sigma^{2} .
$$

The FOC with respect to $\tau$, treating $d$ as given, will be:

$$
\frac{\mu}{\sigma^{2}}=\frac{1-\tau-d}{1-R^{\prime}(\tau)}
$$

The first implication is that, if $R^{\prime}(0)$ is 1 or very close to 1 , the agent will surely use the state to insure, even if there is already church insurance. That is because of the distortive effects of both state and church funding, and the distortion increases with the level of insurance. Thus, the agent would prefer to have some insurance from both sides rather than the entire insurance from one place.

In the above equation, since $d$ as given in equation (6), and $\tau$ as given in equation (7), then, by the implicit function theorem:

$$
-R^{\prime \prime}(\tau) \frac{\partial \tau}{\partial d} \frac{\mu}{\sigma^{2}}=-\frac{\partial \tau}{\partial d}-1
$$

or,

$$
\frac{\partial \tau}{\partial d}=\frac{1}{-1+R^{\prime \prime}(\tau) \frac{\mu}{\sigma^{2}}}
$$


So,

$$
\frac{\partial \tau}{\partial d}<0
$$

The preceding comparative statics indicate that the more religious a person is, the less tax rate they would prefer. The intuition is the following, the marginal benefit of additional taxation is $(1-\tau-d) \sigma^{2}$, which is decreasing in $d$. With a higher level of $d$, the marginal benefit of insurance decreases for the agent, thus in equilibrium, the marginal cost of tax distortions will also decrease, which is done by lowering $\tau$.

\subsection{State Religion}

Now suppose the religion could be a state religion, denoted by $\gamma \in[0,1]$. With a state church, government typically finances building fees and clergy salaries. In the U.S., the average yearly salary of clergy was $\$ 47,540$ in 2013 according to the Bureau of Labor Statistics. The average congregation had 75 regular participants and an annual budget of $\$ 90,000$ (the average attendee worshiped in a congregation with 400 regular participants and annual budget of $\$ 280,000$ ) (Chaves et al., 2009). Clergy salaries and building fees can therefore be a significant contribution to church budget when there is a state church.

In the model, $\gamma=0$ is the case of no-state religion (complete separation of church-state) and examined in the previous sub-section. The degree of state religion increases with $\gamma$ all the way up to 1. $\gamma=1$ would correspond to the case where the church owns the state, and all the state revenues go to the church. The church gets $\gamma$ share of the government revenue with the government retaining $1-\gamma$. Then, the agents' income realization next period will be: $(1-\tau-d) y+(1-\gamma) R(\tau) \mu+$ $P(d)(1+\gamma R(\tau)) \mu$. This would imply the agents' optimization will be:

$$
[1-\tau-d+(1-\gamma) R(\tau)+P(d)(1+\gamma R(\tau))] \mu-\frac{1}{2}(1-\tau-d)^{2} \sigma^{2}
$$

or

$$
[1-\tau-d+R(\tau)+P(d)-(1-P(d)) \gamma R(\tau)] \mu-\frac{1}{2}(1-\tau-d)^{2} \sigma^{2}
$$

First, for a given level of $\tau$, and $d$, the agent gets less insurance income, as part of the insurance goes through the double distortion of the state and church revenue systems, so the level of insurance decreases overall. The distortion is value destroying, so tax preferences when $d$ is low may actually be lower when $\tau$ is high.

The lower separation of church and state and higher degree of state religion, $\gamma$, introduces increased payoff to being more religious, since devout agents will also have access to part of the state tax revenues.

The FOC of the new maximization problem will be:

$$
\left[-1+R^{\prime}(\tau)-\gamma(1-P(d)) R^{\prime}(\tau)\right] \mu+(1-\tau-d) \sigma^{2}=0
$$

or, 


$$
\frac{\mu}{\sigma^{2}}=\frac{1-\tau-d}{1-R^{\prime}(\tau)+\gamma(1-P(d)) R^{\prime}(\tau)} .
$$

The FOC then implies:

$$
\left[R^{\prime \prime}(\tau) \frac{\partial \tau}{\partial \gamma}-\left(1-P(d) R^{\prime}(\tau)-\gamma(1-P(d)) R^{\prime \prime}(\tau) \frac{\partial \tau}{\partial \gamma}\right] \mu-\frac{\partial \tau}{\partial \gamma} \sigma^{2}=0\right.
$$

or,

$$
\left[R^{\prime \prime}(\tau)(1-\gamma(1-P(d)))-\sigma^{2}\right] \frac{\partial \tau}{\partial \gamma}=(1-P(d)) R^{\prime}(\tau)
$$

or,

$$
\frac{\partial \tau}{\partial \gamma}=-\frac{(1-P(d)) R^{\prime}(\tau)}{\left(-R^{\prime \prime}(\tau)\right)(1-\gamma(1-P(d)))+\sigma^{2}}
$$

Since both the numerator and the denominator of the expression are positive, we have that,

$$
\frac{\partial \tau}{\partial \gamma}<0
$$

This is one of the intuitions of the setup: as the level of state-religion increases, insurance through taxation is more value destroying, and therefore the agents would insure less (through lower $\tau$ ).

But as $d$ increases, the numerator decreases, while the denominator increases, which implies that:

$$
\frac{\partial^{2} \tau}{\partial \gamma \partial d}>0
$$

If we assume the functions are continuous, then we also have that:

$$
\frac{\partial^{2} \tau}{\partial d \partial \gamma}=\frac{\partial^{2} \tau}{\partial \gamma \partial d}>0
$$

The negative relationship between religiosity and tax preferences is less extreme when there is a state church because government funding of state churches is unused by agents who are not religious. Note that we obtain our results without assuming that religious agents take from nonreligious agents through the state church. With resource transfer, religious agents prefer more taxes when resources transferred from the non-religious exceed deadweight loss from taxing themselves.

In the general equilibrium, the agents expect the state to set a certain level of church-state separation $\left(\gamma^{e}\right)$, and in the rational expectations equilibrium those expectations will hold true:

$$
\gamma=\gamma^{e}
$$




\subsection{Elite Preferences On Church-State Separation}

We now introduce elites who desire a lower tax burden (Acemoglu and Robinson 2000). We show how their preferences on church-state separation depend on the relative weight of religious and non-religious constituencies and why countries with state religion have higher levels of welfare state.

With heterogenous agents, the religious tax the non-religious through a state church. Religiosity and tax preferences are inversely related when there is separation between church and state, but religiosity and tax preferences are positively related when there is no separation. The predictions of the model can be summarized in a simple diagram:

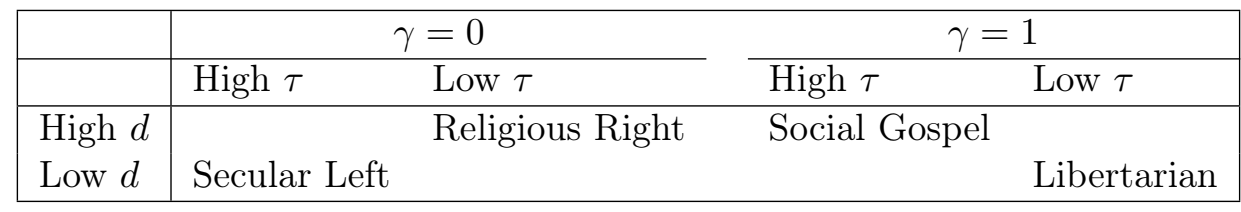

Without a state church $(\gamma=0)$, the highly religious prefer low taxes (Religious Right) and the less religious prefer high taxes (Secular Left). With a state church $(\gamma=1)$, the highly religious prefer high taxes (Social Gospel) while the less religious prefer low taxes (Libertarian). The decision to separate church and state appears to be more a decision of the elites judiciating in a court of law than a decision by popular vote, so we let elites choose $\gamma$ and voters choose $\tau$.

\subsection{Multiple Steady States}

We consider a dynamic growth model of religiosity and separation of church and state. Each equation below relates the motion of one of the variables to another. Define $d_{t}$ as the share of religious people in the society at time $t ; \gamma_{t}$ is the amount of tax revenues that is given to the church (that is the higher $\gamma_{t}$ indicates a lower separation of church and state); $w_{t}$ is the level of the welfare state in the economy.

The first equation governing the process will be:

$$
\gamma_{t}=\alpha-\beta d_{t}
$$

This equation means that a high level of religiosity is associated with greater separation of church and state. It is the equation that sets up the elites' behavior, who curb the tax preferences of the religious left when there are many religious individuals by separating church and state, or do the opposite when the population is mostly secular.

The second equation of the process will be:

$$
w_{t}=\alpha_{\gamma}-\beta_{\gamma} \gamma+\alpha_{d}-\beta_{d} d+\beta_{\gamma d} \gamma d \text {. }
$$

The equation is derived from the equilibrium outcome of interplay between government and church insurance. Elites curb tax preferences of the population by separating church and state when there are many religious individuals. ${ }^{18}$ When there are few religious individuals, elites curb tax preferences by keeping a large state church. ${ }^{19}$ Thus, the second partial with respect to $\gamma$ and $d$ is

\footnotetext{
${ }^{18}$ As $\gamma$ goes to 0 , the relationship between $w_{t}$ and $d$ is negative.

${ }^{19}$ As $d$ goes to 0 , the relationship between $w_{t}$ and $\gamma$ is negative.
} 
positive. Each of $\beta, \beta_{d}$, and $\beta_{\gamma}$ are also positive. Using equation (22), equation (23) can be rewritten as:

$$
w_{t}=\left(\alpha_{\gamma}-\beta_{\gamma} \alpha+\alpha_{d}\right)+\left(\beta_{\gamma} \beta-\beta_{d}+\alpha \beta_{\gamma d}\right) d_{t}-\beta_{\gamma d} \beta d_{t}^{2}
$$

or,

$$
w_{t}=b_{1}+b_{2} d-b_{3} d^{2} .
$$

Finally, we close the model. Many empirical studies document that government welfare crowds out religious participation and charitable provision (Gruber and Hungerman 2007; Hungerman 2005; Gill and Lundsgaarde 2004; Cnaan et al. 2002). We model this crowd-out by assuming that as welfare state increases, the marginal person seeking insurance will turn to the welfare state instead of religion, so average religiosity declines:

$$
n_{t}=\frac{1}{\phi w_{t}}=\frac{1}{a_{1}+a_{2} d_{t}-a_{3} d_{t}^{2}}
$$

The evolution of $d_{t}$ is as folows: at each subsequent period, the stock of religiosity decays by a constant fraction $\delta$. However, it gets supplemented by the average new religiosity, as described in equation (24). Then, the dynamics of religiosity will follow as:

$$
d_{t+1}=d_{t}(1-\delta)+n_{t}
$$

Therefore, the steady state would satisfy:

$$
d=d(1-\delta)+\frac{1}{a_{1}+a_{2} d-a_{3} d^{2}}
$$

Or,

$$
\delta a_{3} d^{3}-\delta a_{2} d^{2}-\delta a_{1} d+1=0 .
$$

This equation has three roots. If all are real, $d(1-\delta)+\frac{1}{a_{1}+a_{2} d-a_{3} d^{2}}$ will intersect the $45^{\circ}$ at three places. Even though all three points represent steady states, we can characterize them as follows. Since $a_{3}$ is positive as is the constant term 1, at most two of the roots are positive. Second, $a_{3}>0$ implies that the two endpoints are unstable while the middle root is stable. In cases where the equation has one real and two complex roots, the unstable steady state is the only interior steady state. in this case, the two stable equilibria are $d=0$ and $d=1$.

This model is consistent with the intuition that when there are many religious individuals, the elites separate church and state, curbing tax preferences of the religious left, reducing the welfare state, which increases subsequent religiosity for the marginal person, creating a positive feedback. However, when there are few religious individuals, elites keep a large state church, attempting to curb the tax preferences of the secular left, reducing the welfare state, which increases subsequent religiosity, creating a negative feedback and stable steady state. 
To see this, let's take the right-most intersection point, and a point slightly to the left of it. At that point then,

$$
\delta a_{3} d_{t}^{3}-\delta a_{2} d_{t}^{2}-\delta a_{1} d_{t}+1<0
$$

Or,

$$
\begin{gathered}
\delta a_{3} d_{t}^{3}-\delta a_{2} d_{t}^{2}-\delta a_{1} d_{t}<-1 \\
\delta d_{t}\left(a_{3} d_{t}^{2}-a_{2} d_{t}-a_{1}\right)<-1
\end{gathered}
$$

Since, $\delta d_{t}>0$, we then have $a_{3} d_{t}^{2}-a_{2} d_{t}-a_{1}<0$. Then,

$$
\begin{aligned}
& \delta d_{t}>\frac{-1}{a_{3} d_{t}^{2}-a_{2} d_{t}-a_{1}}=\frac{1}{a_{1}+a_{2} d_{t}-a_{3} d_{t}^{2}} \\
& d_{t}>(1-\delta) d_{t}+\frac{1}{a_{1}+a_{2} d_{t}-a_{3} d_{t}^{2}}
\end{aligned}
$$

\section{DATA}

We draw on several data sets: (1) an annual survey of randomly sampled U.S. residents for their religious attendance, and political support for welfare spending and the Republican party, as well as demographic characteristics such as income, education, and race (General Social Survey (GSS), 19722012); (2) similar data from the World Values Survey (WVS), Waves 1-5; (3) church-state separation measures from the World Christian Encyclopedia and Finke and Grim (2006), who aggregate U.S. State Department data (International Religious Freedom Reports). They classify countries as having

Figure 2: Multiple Steady States

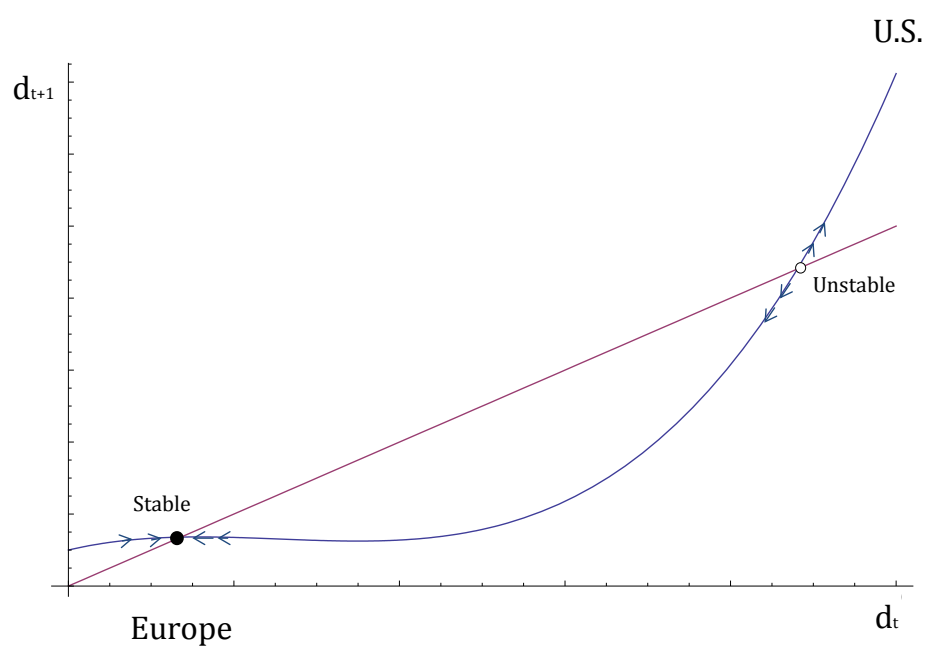


a state religion if the constitution designates an official state church and restricts or prohibits other forms of religion, if the government systematically favors a specified religion through subsidies and tax collection, or if the government sanctions teaching of religion in public school. For a list of countries, see Appendix Table XVII. Our data contain a number of variables on religious regulation and favoritism and are based on what is actually taking place in the country more than what legal regulations say should be the case.

Data on philanthropic giving come from the 2001 Center on Philanthropy Panel Study portion of the Panel Study of Income Dynamics; the main question of interest is, "Did you make any donations specifically for religious purposes or spiritual development, for example to a church, synagogue, mosque, TV or radio ministry? Please do not include donations to schools, hospitals, and other charities run by religious organizations." This data is merged with the GSS. Summary statistics by denomination and denomination categories are taken from Smith (2004). Our natural experiments draw on data from the Swedish and Norwegian Election Surveys and cases coded from the U.S. Supreme Court and U.S. Circuit Courts. Other datasets used in the Circuit Courts natural experiment include: judicial biographies to instrument for the direction of the case and District Court data to instrument for the presence of a case. See Chen and Yeh (2014) for further details.

The main measure of welfare support in the GSS is the response to the question: "We are faced with many problems in this country, none of which can be solved easily or inexpensively. Are we spending too much money, too little money, or about the right amount on welfare?" "Too little money" is coded as 1 and the other responses coded as 0 . The only measure of welfare support in the WVS asked across panel waves is the response to the question, "The state should take more responsibility to ensure that everyone is provided for."20 Too little is coded as 1 . The categories, "too much" and "about right", are distributed similarly with respect to religious attendance. Other variables of interest are also coded as 1-0 for consistency and ease of interpretation. ${ }^{21}$

All regressions include regional fixed effects to control for omitted environmental variables that may influence the way political support differs across space. All specifications also include dummies for year, race, gender, and controls for log of income ${ }^{22}$, age, age-squared, and years of completed schooling (dummies for categories of completed schooling in WVS). When controls are missing, we dummy them out. ${ }^{23}$ All estimates discussed below are marginal effects from probit models evaluated at sample means. Standard errors are adjusted for correlation within region of residence. Summary statistics are displayed in Appendix Table 1. The data appendix discusses the remaining variable definitions.

\section{FISCAL AND SOCIAL CONSERVATISM/LIBERALISM}

While fiscal and social conservatives and fiscal and social liberals have been found to come hand-in-hand in congressional roll-call votes (Converse 1964; Poole and Rosenthal 1997) and across countries (Scheve and Stasavage 2006; Cavanaugh 2005; Gill and Lundsgaarde 2004), we present new evidence that these patterns hold within countries at the individual-level. First, we replicate others

\footnotetext{
${ }^{20}$ Wave 1 does not ask this question.

${ }^{21}$ Note that all questions ask about "increases" or "decreases." Unfortunately, the GSS and WVS do not ask people for their beliefs about the current level of welfare support.

${ }^{22}$ Our preferred measure of income is the log of income measured by the REALINC variable in GSS. The raw data collected from respondents is bracketed. REALINC is created by taking the mid-point of the brackets and fitting a Pareto distribution on the top bracket, and then adjusting for inflation. See Ligon (1994) for details. Alternative measures of income have virtually no impact on the estimated parameters on religion.

${ }^{23}$ Dropping observations when controls are missing and dummying them out (by adding an indicator for whether the control is missing and filling in the missing control with a constant) both assume that controls are missing at random, but the latter approach yields greater precision for other control variables that are present.
} 
in finding that the pattern holds within the U.S. Figure 1 in the introduction plots welfare support as it varies with religious attendance. Welfare support declines as religious attendance increases. Roughly $22 \%$ of those who never attend religious services support more welfare while around $14 \%$ of weekly attenders support more welfare. The inverse relationship between welfare support and religious attendance remains when controlling for demographic background characteristics, as shown in Table I, which reports results from regressions of the form:

$$
\begin{aligned}
\text { FiscalConservatism }_{i} & =\beta_{0} \text { Religion }_{i}+\beta_{1} \text { Fundamentalist }_{i}+\alpha^{\prime} \text { Controls }_{i}+\varepsilon_{i} \\
\text { MoralConservativsm }^{\prime} & =\beta_{0} \text { Religion }_{i}+\beta_{1} \text { Fundamentalist }_{i}+\alpha^{\prime} \text { Controls }_{i}+\varepsilon_{i}
\end{aligned}
$$

Religion $_{i}$ measures religious attendance and Fundamentalist ${ }_{i}$ measures the whether the respondent's religious denomination is fundamentalist. ${ }^{24}$ FiscalConservatism $_{i}$ and MoralConservativsm $_{i}$ are collections of responses to questions that can be classified as measuring whether the respondent is fiscally conservative (i.e., favoring low taxes and low government expenditures) and morally conservative (i.e., favoring restrictions on abortion and related issues). The choice of variables comes from Ansolabehere et al. (2006). We present a single coefficient for all the regressions on measures of fiscal conservatism and social conservatism using the average effect size approach of Kling et al. (2004) and Clingingsmith et al. (2009). ${ }^{25}$

Increasing eight categories of religious attendance from "never attend" to "several times a week" yields an increase in $11 \%$ of a standard deviation in fiscal conservatism and $72 \%$ of a standard deviation in moral conservatism. Members of fundamentalist denominations are $5 \%$ of a standard deviation more fiscally conservative and $28 \%$ of a standard deviation more morally conservative. ${ }^{26}$

The individual regressions upon which the average effect size estimation is based are shown in Figure $3,{ }^{27}$ where all the responses have been normalized to have unit standard deviation. We notice that religious attendance has a quite similar effect on most outcomes, and it has a positive and significant effect in most cases. As we might expect, the effects are quantitatively larger for moral conservatism than fiscal conservatism.

Outside the U.S., religious attendance also predicts fiscal conservatism, but in countries without a state church (Column (2) of Table III). The coefficients are not strictly comparable. There are fewer categories of religious attendance in the WVS and the question on welfare support is asked slightly differently, with the GSS asking about government spending on welfare and the WVS asking about government action on poverty. For example, in the GSS, 20\% of respondents are pro-welfare whereas in the WVS, $40 \%$ of U.S. respondents are pro-welfare. Religious attendance also predicts social conservatism around the world. Appendix Table XVI shows results on measures of child obedience/ownership, women's role, sexual activity, and moral absolutism.

\footnotetext{
${ }^{24}$ The GSS classifies denominations as religious fundamentalist or not. We report qualitatively similar results from a specification that replaces Fundamentalist with a general index of Social Conservatism, summing up values on Prayer in Public School, Women Belong at Home, Premarital Sex is Wrong, and Identify as Fundamentalist in Appendix Table VII. The four measures are highly correlated; a factor analysis reveals one dominant factor, where all four variables have about equal factor loadings.

${ }^{25}$ Results remain qualitatively unchanged, if instead, we run regressions on the principal components of the variables. The advantage of the AES approach is that we do not have to impute missing values. The AES averages the normalized effects obtained from a seemingly unrelated regression in which each dependent variable is a question in the index. Normalization is based on the control group, which is no attendance. In the appendix, we show one exception to the general pattern of fiscal conservatism-religious attenders prefer military spending.

${ }^{26}$ Religious attendance and fundamentalism does not seem to reinforce each other. In Appendix Table VI we interact the two. Estimates are small and far from being significant.

${ }^{27}$ See Appendix Table IX for the detailed estimates underlying the graph as well as corresponding regressions on the measure of social conservatism.
} 
TABLE I

Fiscal and Social Conservatism/Liberalism in the U.S. - Average Effect Sizes

\begin{tabular}{lcccccccc}
\hline & \multicolumn{3}{c}{ Fiscal conservative } & & \multicolumn{3}{c}{ Moral conservative } \\
\cline { 2 - 3 } & $(1)$ & $(2)$ & $(3)$ & & $(4)$ & & $(5)$ & $(6)$ \\
\hline Religious attendance & $0.0140^{* * *}$ & & $0.0129^{* * *}$ & & $0.0904^{* * *}$ & & $0.0859^{* * *}$ \\
& $(0.00195)$ & & $(0.00198)$ & & $(0.00351)$ & & $(0.00310)$ \\
Fundamentalist & & $0.0466^{* * *}$ & $0.0325^{* * *}$ & & $0.277^{* * *}$ & $0.200^{* * *}$ \\
& & $(0.0104)$ & $(0.0109)$ & & $(0.0249)$ & $(0.0118)$ \\
\hline Observations & 54541 & 52971 & 52585 & & 56170 & 54593 & 54197 \\
\hline Notes: & & & & & & &
\end{tabular}

1. Data are from General Social Survey cumulative file, 1972-2012. All estimates are average effect size estimates. Standard errors in parentheses are adjusted for correlation within region of residence. *, ** and *** denote significance at the 10, 5 and $1 \%$ level.

2. All specifications include dummies for region of residence, marital status, year, race, and gender, and controls for the log of income, age, age-squared, and years of completed schooling.

3. Missing values in control variables are replaced by the value 0 and a dummy for the variable being missing is included.

4. Fundamentalist is a dummy for belonging to a fundamentalist religious denomination.

\section{DIFFERENCES IN SOCIAL INSURANCE BY DENOMINATION}

In this section, we present evidence that not only are more religiously intense individuals more socially conservative and fiscally conservative, but denominations ${ }^{28}$ that provide more mutual in-

\footnotetext{
${ }^{28}$ The classification of denominations is based on the RELTRAD method due to Steensland et al. (2000). See http://www.github.com/thebigbird/ReltradStata for an updated version of their code.
}

Figure 3: Fiscal and Social Conservatism/Liberalism in the U.S. - All estimates
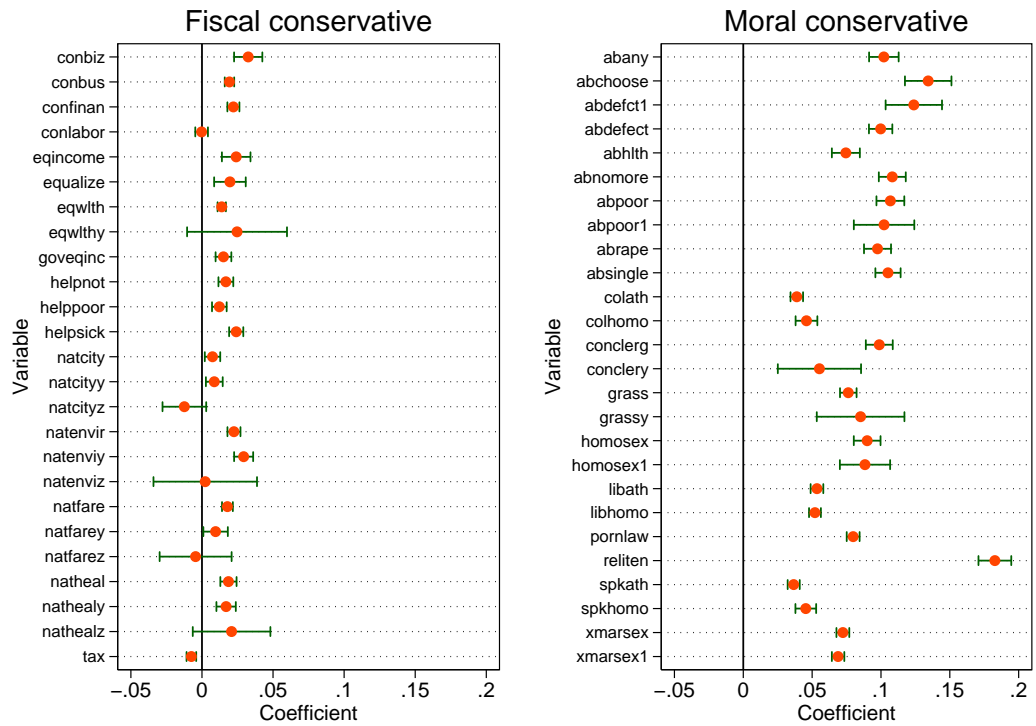

Notes: The graphs show all the estimated coefficients on religious attendance for outcomes on fiscal and moral conservativeness as well as their 95\% confidence intervals. Estimated coefficients are from OLS regressions controlling for the same variables as Table I. Standard errgrs are clustered at the region of residence. 
TABLE II

Within-Group Giving and Fiscal/Social Conservatism in the US

Fiscal conservative Moral conservative

(1)

\begin{tabular}{lcc}
\hline Within-group giving & $\begin{array}{c}0.421^{* * *} \\
(0.0373)\end{array}$ & $\begin{array}{c}1.055^{* * *} \\
(0.0828)\end{array}$ \\
\hline Observations & 42545 & 43727 \\
\hline
\end{tabular}

Notes:

1. Data are from General Social Survey cumulative file, 1972-2012. All estimates are average effect sizes. Dependent variables are as in Table I. Standard errors in parentheses are adjusted for correlation within region of residence. *, ** and *** denote significance at the 10, 5 and $1 \%$ level.

2. All specifications include dummies for region of residence, marital status, year, race, and gender, and controls for the log of income, age, age-squared, and years of completed schooling.

3. Missing values in control variables are replaced by the value 0 and a dummy for the variable being missing is included.

surance are more socially conservative and fiscally conservative. The degree of within-group giving varies widely across denomination. Mormons give $91 \%$ of their charitable giving to religion, Evangelical Protestants 82\%, Mainline Protestants 62\%, Catholics 51\%, Other Religions 51\%, Jewish $40 \%$, and None $40 \%$ (Appendix Table XIII). ${ }^{29}$

The percentage of overall income given to religion also roughly corresponds with the same ordering. ${ }^{30}$ Religious donations are defined as donations specifically made for religious purposes or spiritual development, for example to local church, TV, or radio ministry. Donations to schools, hospitals, arts, and international aid are excluded. ${ }^{31}$

Table II reports results from average effect estimations based on regressions where different opinions are regressed on the fraction of charitable giving that goes to religion. ${ }^{32}$ Regressions are of the form:

$$
\text { WelfareSupport }_{i}=\beta \text { WithinGroupGiving }_{i}+\alpha^{\prime} \text { Controls }_{i}+\varepsilon_{i}
$$

As one moves 50 percentage points of within-group giving from the lowest (40\%) to the highest (91\%), $20 \%$ of a standard deviation in fiscal conservative attitudes and $50 \%$ of a standard deviation in moral conservative attitudes are shifted.

Figure 4 displays the coefficients on denomination fixed effects in analogous regressions reported in Appendix Table X. Regressions are of the form:

$$
\text { WelfareSupport }_{i}=\beta \text { Denomination }_{i}+\alpha^{\prime} \text { Controls }_{i}+\varepsilon_{i}
$$

For each fiscal or social attitude, individuals who are members of more conservative/liberal denominations report more extreme positions. Groups with greater within-group giving, such as Mormons

\footnotetext{
${ }^{29}$ Denomination groupings come from Smith (2004). Analyzing all waves of the COPP data show the within-group giving percentages are very stable over time.

${ }^{30}$ Members of denominations with higher degrees of within-denomination giving also attend religious services more frequently than others. For attendance more than once a month: Mormon 66\%, Evangelical Protestant 56\%, Mainline Protestant 57\%, Catholic 48\%, Other 40\%, Jew 15\%, None 25\%.

${ }^{31}$ COPPS asks other questions for these donation categories.

${ }^{32}$ The separate regressions can be found in Appendix Table X and regresions for each denomination in Appendix Table XIII.
} 
and Evangelical Protestants, tend to be more socially conservative on prayer, abortion, women's roles, and premarital sex. They are also more fiscally conservative, being less supportive of welfare and equality and being more likely to identify as Republican, politically conservative, and fundamentalist. ${ }^{33}$

\section{CHURCH-STATE SEPARATION}

\subsection{Cross-Country Evidence}

Do social conservatives become fiscal liberals if there is a state church? To test this, we regress stated welfare support on religious attendance and attendance interacted with a dummy if the respondent's country has a state church. Regressions are of the form:

$$
\begin{aligned}
\text { WelfareSupport }_{i j}=\beta_{0} \text { Attendance }_{i j}+\beta_{1} \text { Attendance }_{i j} \times \text { StateChurch }_{j} \\
+\beta_{2} \text { StateChurch }_{j}+\alpha^{\prime} \text { Controls }_{i j}+\varepsilon_{i j}
\end{aligned}
$$

The results are shown in Table III. Column (1) simply runs the specification from Table I and Figure 3 in the WVS. In general, increased church attendance is associated with lower support for government-provided welfare, but the negative relationship is only statistically significant for countries without a state church (Column 2). In countries without a state church, an individual who moves 6 categories of religious attendance decreases about 0.12 points in support for government welfare (the mean level of support is 6.3 on a 10-point scale).

Religious attendance, according to the WVS, is similarly strongly related to less welfare support for most other countries of the world, confirming that our proposition holds across a wide range of countries. Figure 3 shows that welfare support declines with religious attendance in most countries

\footnotetext{
${ }^{33}$ Reasonable data to undertake similar analyses for the worldwide sample are not available in the WVS so we have not been able to do that.
}

Figure 4: Fiscal and Social Conservatism/Liberalism in the U.S. - All estimates
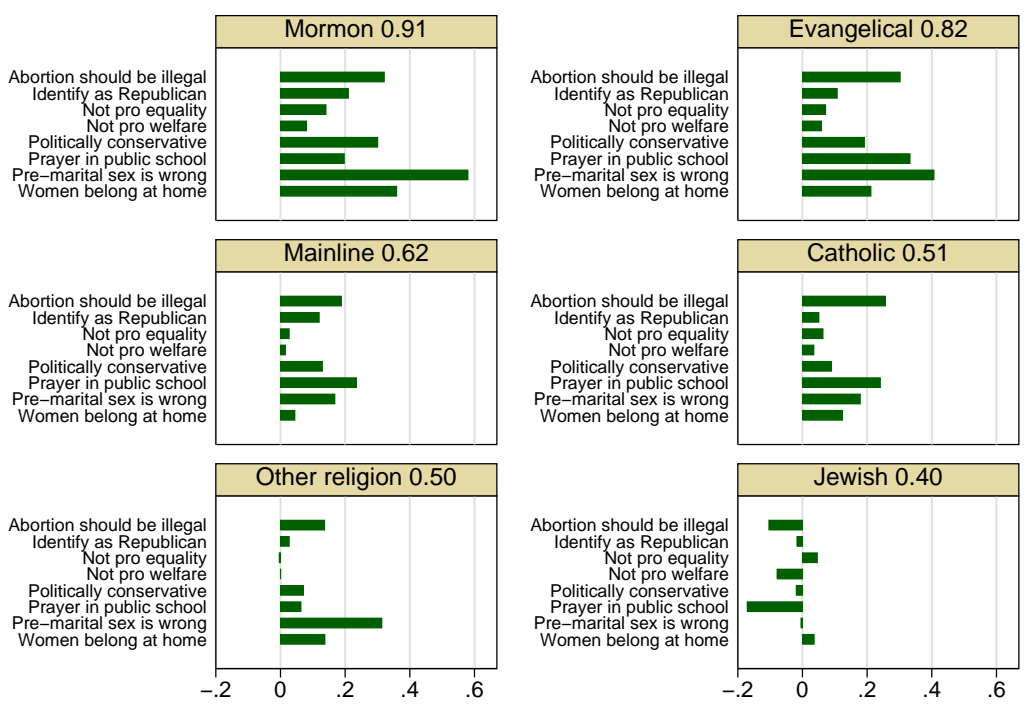
TABLE III

Fiscal Conservatism and Church-State Separation Across the World

\begin{tabular}{|c|c|c|c|c|c|c|}
\hline & \multicolumn{3}{|c|}{ Gov. responsibility } & \multicolumn{3}{|c|}{ Reduce inequality } \\
\hline & $(1)$ & $(2)$ & $(3)$ & $(4)$ & $(5)$ & (6) \\
\hline Attendance & $\begin{array}{c}-0.00883 \\
(0.00534)\end{array}$ & $\begin{array}{c}-0.0216^{* * *} \\
(0.00562)\end{array}$ & $\begin{array}{c}-0.0181^{* * *} \\
(0.00575)\end{array}$ & $\begin{array}{c}0.00382 \\
(0.00652)\end{array}$ & $\begin{array}{c}0.00480 \\
(0.00897)\end{array}$ & $\begin{array}{c}0.00352 \\
(0.00766)\end{array}$ \\
\hline Attendance $\times$ Has SC & & $\begin{array}{c}0.0309^{* * *} \\
(0.0114)\end{array}$ & & & $\begin{array}{c}-0.00244 \\
(0.0134)\end{array}$ & \\
\hline Attendance $\times$ Belong to $\mathrm{SC}$ & & & $\begin{array}{c}0.0420^{* *} \\
(0.0161)\end{array}$ & & & $\begin{array}{r}-0.00327 \\
(0.0131)\end{array}$ \\
\hline Belongs to SC & & & $\begin{array}{c}-0.304^{*} \\
(0.163) \\
\end{array}$ & & & $\begin{array}{c}0.119 \\
(0.117) \\
\end{array}$ \\
\hline Mean of dep. variable & 6.239 & 6.239 & 6.239 & 5.946 & 5.946 & 5.946 \\
\hline $\mathrm{R}^{2}$ & 0.0982 & 0.0983 & 0.0985 & 0.112 & 0.112 & 0.112 \\
\hline Observations & 220001 & 220001 & 220001 & 215304 & 215304 & 215304 \\
\hline
\end{tabular}

Notes:

1. Data are from World Values Survey cumulative file, waves 2-5. All estimates are OLS estimates. Standard errors in parentheses are adjusted for correlation within country of residence. *, ** and *** denote significance at the 10,5 and $1 \%$ level.

2. The question for the Government responsibility variable is "People should take more responsibility to provide for themselves vs. The government should take more responsibility to ensure that everyone is provided for." The question for the Reduce inequality variable is "Incomes should be made more equal vs. We need larger income differences as incentives." Both are measured on a 1-10 scale.

3. All specifications include dummies for country of residence, survey wave, gender, marital status, and educational attainment category and controls for income, age, and age squared.

4. Missing values in control variables are replaced by the value 0 and a dummy for the variable being missing is included.

5. Data on church-state separation are from Barro and McCleary (2005), which is based on Barrett (1982) and Barrett et al. (2001).

for which we have data. ${ }^{34}$ The bars indicate the coefficient between religious attendance and welfare support for each country in the World Values Survey. In the appendix, we show that religious attendance is strongly correlated with social conservatism.

Of main interest is whether a state church reduces the negative correlation between religion and welfare support. Column (2) of Table III shows that in countries with a state church, the correlation is about zero. In Column (3), we interact the attendance variable with an indicator for whether the respondent belongs to the denomination of the state church in his or her country:

$$
\begin{array}{r}
\text { WelfareSupport }_{i j}=\beta_{0} \text { Attendance }_{i j} \\
+\beta_{1} \text { Attendance }_{i j} \times \text { BelongToStateChurch }_{i j} \\
+\beta_{2} \text { BelongToStateChurch }_{i j}+\alpha^{\prime} \text { Controls }_{i j t}+\varepsilon_{i j}
\end{array}
$$

where BelongToStateChurch $i j$ is an indicator of individual $i$ lives in a country $j$ with a state church and belongs to it. Now we see that for members of the state church, attendance is actually

\footnotetext{
${ }^{34}$ Detailed estimates with standard errors and broken down by wave are available in Appendix Table XV.
} 
associated with more positive attitudes to government welfare. For members of a state church, an individual who moves 6 categories of religious attendance decreases about 0.14 points in support for government welfare (the mean level of support is 6.3 on a 10 -point scale).

One concern could be that it is not attitudes towards the welfare state, but attitudes towards inequality that drive these opinions. To test this, we examine opinions on economic inequality. Religious attendance has no significant relationship with attitudes towards economic inequality (Columns (4) to (6) of Table III), and this applies to countries both with and without a state church.

These regressions restrict the marginal effect of going from one category of church attendance to another to be the same across all categories. To consider possible nonlinearities, Figure 6 displays the conditional correlations between welfare support and dummies for each level of religious attendance

Figure 5: Welfare attitudes and religious attendance across the world

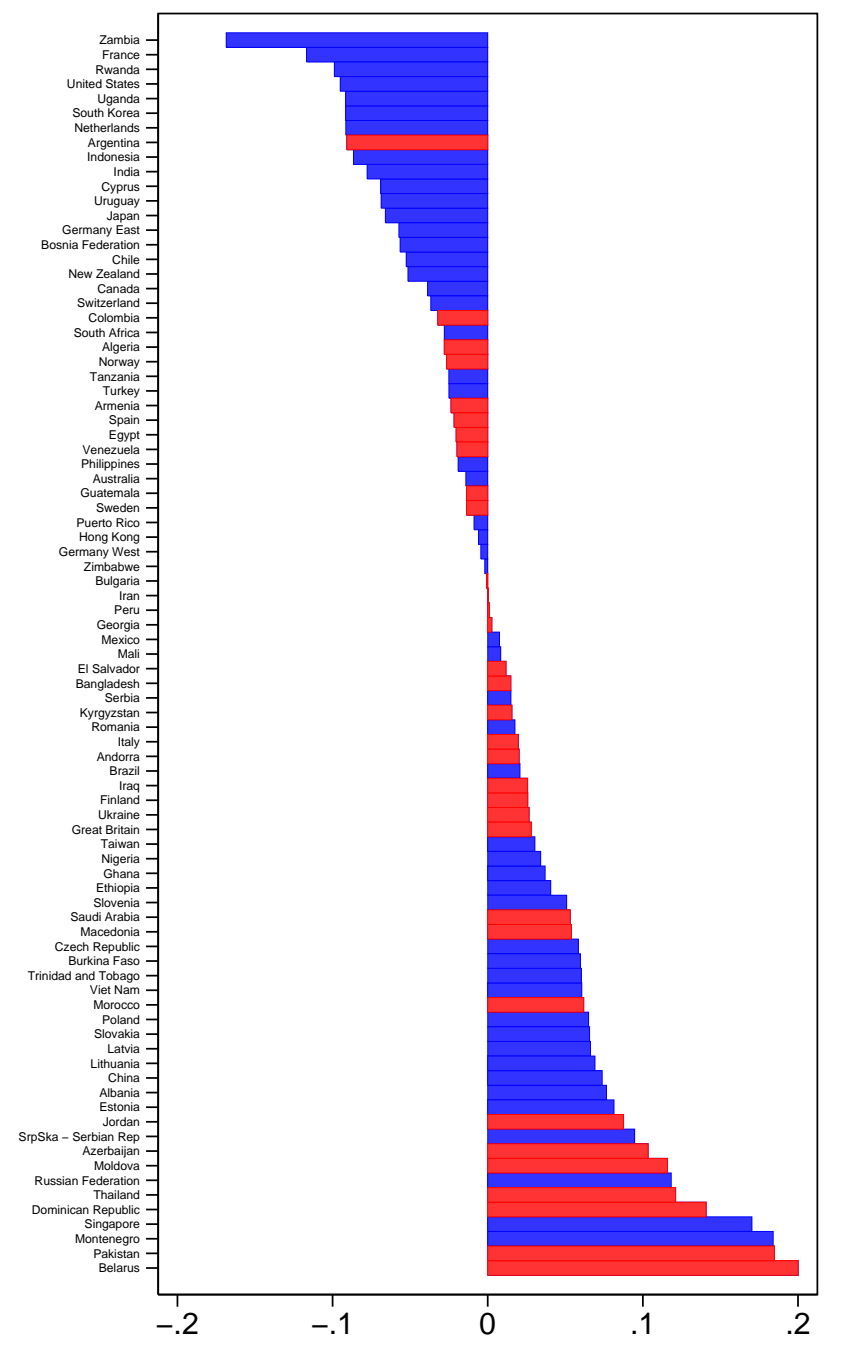

Notes: Bars show the magnitude of the association between religious attendance and preferences for redistribution. Blue bars indicate countries without a state church and red bars indicate countries with a state church. 
(the omitted category is no attendance ${ }^{35}$ ), which corroborates the findings above. In addition, we can drop individuals who claim no religion and do not attend services and the results are identical. That is, our results are robust to dropping atheists.

Figure 6: Welfare Attitudes and Church-State Separation Across the World

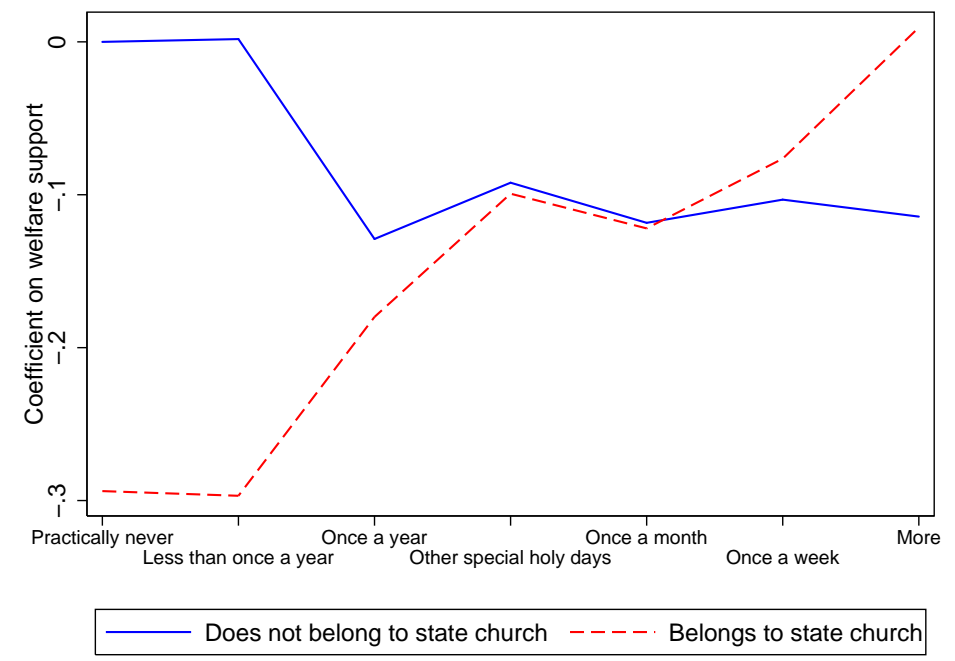

Notes: The solid line indicates the relationship between welfare support and religious attendance for individuals who belong to the state church and the dashed line indicates the relationship for individuals who do not belong to the state church. The regression specification is similar to that of Column (3) in Table III. The category "Only on special holy days/Christmas/Easter days" was only mentioned in Wave 2 and has been merged with the category "Only on special holy days".

One interesting finding is the negative coefficient on belong to state church, which is consistent with the model equation (18). Tax preferences decline with a state church because of double-taxation. Equation (19) predicts a significant positive coefficient on the interaction between religiosity and belonging to the state church.

The classification of which countries have state churches is largely based on constitutional features (collated by the World Christian Encyclopedia (Barrett 1982, Barrett et al. 2001)) and somewhat opaque as to the mechanisms. Preferences for redistribution depend more on the policy actually conducted within the country. To address this, we turn to measures of government regulation, social regulation, and government favoritism, indices developed by Finke and Grim (2006). ${ }^{36}$ Descriptive statistics of these indices are shown in Appendix Table IV. We also see that there is high consistency between the two data sources as Finke and Grim's (2006) indices are significantly larger for countries coded with a state church in the World Christian Encyclopedia.

According to Finke and Grim (2006), government regulation is the most visible form of regulation and the one that receives the most scholarly attention. They define government regulation as "restrictions placed on the practice, profession, or selection of religion by the official laws, policies, or administrative actions of the state." These restrictions range from prohibitions on conversion and prosyltizing to government pamphlets that warn about certain minority religions that may openly

\footnotetext{
${ }^{35}$ Note that people can belong to the state church yet not attend services.

${ }^{36} \mathrm{~A}$ number of other measures of state-church association exist. The Religion and State (RAS) database developed by Fox $(2008 ; 2011)$ could be an alternative to our data. However, his main focus is state involvement in religious life in general with less emphasis on favoritism of the state religion. For this reason we have not used his data.
} 
appeal to youth. Government restrictions against religions can also come in the form of blatant laws against their existence or more subtle administrative restrictions that limit their operations. Minority religious groups can face zoning restrictions or find it difficult to attain tax-exempt status. Government favoritism also involves state action and frequently works in tandem with government regulation. Social regulation refers to the restrictions placed by other religious groups and is not dependent on the state's action (Finke and Grim 2006). While each measure appears individually significant in interaction with religious attendance, it is government regulation that appears to be the driving mechanism. When government regulation reaches 5 (roughly the mean value for countries with a state church according to Barrett et al. (2001)) on the 0-10 index, religious attendance predicts more welfare support.

TABLE IV

Welfare Attitudes and Church-State Separation Across the World

\begin{tabular}{|c|c|c|c|c|c|c|}
\hline & (1) & $(2)$ & $(3)$ & $(4)$ & $(5)$ & (6) \\
\hline Attendance & $\begin{array}{l}-0.00883 \\
(0.00534)\end{array}$ & $\begin{array}{c}-0.0330^{* * *} \\
(0.00718)\end{array}$ & $\begin{array}{c}-0.0251^{* *} \\
(0.00982)\end{array}$ & $\begin{array}{c}-0.0275^{* *} \\
(0.0105)\end{array}$ & $\begin{array}{c}-0.0338^{* * *} \\
(0.00837)\end{array}$ & $\begin{array}{l}-0.0144 \\
(0.0119)\end{array}$ \\
\hline GRI $\times$ Attendance & & $\begin{array}{c}0.00668 * * * \\
(0.00182)\end{array}$ & & & & $\begin{array}{l}0.0102^{* * *} \\
(0.00310)\end{array}$ \\
\hline SRI $\times$ Attendance & & & $\begin{array}{c}0.00353^{*} \\
(0.00186)\end{array}$ & & & $\begin{array}{l}-0.00560^{*} \\
(0.00287)\end{array}$ \\
\hline GFI $\times$ Attendance & & & & $\begin{array}{l}0.00347^{*} \\
(0.00193)\end{array}$ & & $\begin{array}{l}-0.00543 \\
(0.00380)\end{array}$ \\
\hline Attendance $\times$ Government favoritism & & & & & $\begin{array}{c}0.00787^{* * *} \\
(0.00257)\end{array}$ & $\begin{array}{c}0.00816 \\
(0.00539)\end{array}$ \\
\hline Mean of dep. variable & 6.239 & 6.287 & 6.287 & 6.287 & 6.287 & 6.287 \\
\hline $\mathrm{R}^{2}$ & 0.0982 & 0.0915 & 0.0913 & 0.0913 & 0.0914 & 0.0915 \\
\hline Observations & 220001 & 214282 & 214282 & 214282 & 214282 & 214282 \\
\hline
\end{tabular}

Notes:

1. Outcome variable is "People should take more responsibility to provide for themselves vs The government should take more responsibility to ensure that everyone is provided for."

2. Explanatory variables are GRI: Government Regulation index, SRI: Social Regulation Index, GFI: Government Favoritism Index, Government Favoritism: Financial support and other privileges for specific religious group.

3. Controls are as in Table III.

4. Missing values in control variables are replaced by the value 0 and a dummy for the variable being missing is included.

5.Standard errors in parentheses are adjusted for correlation within country of residence. *, ** and *** denote significance at the 10, 5 and $1 \%$ level.

\subsection{Swedish Abolition of State Church in 2000: Differences-in-Differences-in-Differences}

Since the Reformation in the 16th century, the Nordic countries have had state churches. Among other powers, the state provided or administered the funding of churches and had a major influence on the naming of priests and bishops. Sweden has debated the potential abolition of the state church since the 1970s. ${ }^{37}$ Following the 1994 recommendations of the "Preparatory Committee on Church Matters," separation of state and churchwas passed in the parliament in December 1995 with support of all parties except the Left party, which favored an even stronger separation. The

\footnotetext{
${ }^{37}$ See Ekström (2003) and Gustafsson (2003) for detailed accounts of the debate leading up to the abolition of the state church in Sweden.
} 
change in the relationship was implemented as of January 1, 2000. The Church of Sweden was then free from the state, but remained an open national Evangelical-Lutheran church. Also, unlike other religious bodies, the Church of Sweden had an automatic right of state support in levying church fees (Sidenvall 2012). However, non-members of the Church of Sweden were not subject to church taxes any longer (Ekström 2003, 214). Before the separation of the state and the Church of Sweden, children of parents who were members of the Church of Sweden automatically became members of the Church of Sweden. After the separation decision, children only become members if they were baptized (see Brohed (2005, Ch. 20 and 26) for details).

The Norwegian church-state model was quite similar to the Swedish model, but for a long time there was no serious debate on separating state and church. However, in 2006, the Gjønnes commission recommended a partial separation that was passed in the parliament and implemented in May 2012. The Church of Norway was no longer formally a state church; it was transformed into a "people's church." Still, financing remained a governmental duty. See Thorkildsen (2012) for further details.

Separation of state and church in Scandinavia, even though not adjudiciated, was not really a matter of popular vote. There was little popular debate; instead, a long series of committee reports were issued between church and government (Rasmussen 2007, 1). Debate, if any, was mainly within the Church of Sweden; the Centre party (Centern) was the only political party voicing any real disagreement (Ekström 2003, 223). In the end, the decision was taken by a small group at the top of the party, which may make the exact timing of the separation plausibly exogenous. Notably, the Left party favored even a smaller state church. Until the 1960s, i.e. during growth of the welfare state, the abolition of the state church was in the program of the Social Democrats in Sweden (Gustafsson 2003: 55), which is consistent with the model: those on the left prefer to increase separation of church and state to increase the tax preferences of the secular population.

We study whether the Swedish abolition of the state church in 2000 had an impact on preferences, specifically on the relationship between religiosity and preferences for redistribution. To account for trends unrelated to the abolition of the state church, we compare redistributive preferences in Sweden to preferences in Norway, which retained its state church throughout the period we study. We use a differences-in-differences-in-differences approach between Sweden and Norway before and after the Swedish abolition of the state church in 2000. Data are drawn from the election studies in the two countries. Swedes with greater self-reported Christian values become more inclined to cut taxes on high income individuals after separation. Descriptive statistics can be found in Appendix Table V.

Table V shows the results of these regressions. Columns (1) to (5) measure redistributive preferences by the answer to questions on whether taxes on high incomes should be reduced; Columns (6) to (10) look at beliefs about whether income differences should be reduced, which serves as a check that the first question measures welfare attitudes rather than attitudes towards inequality. As consistent data on religious attendance is unavailable, we measure religiosity by the respondent's answer on a five point scale to whether it would be beneficial for their society to be more closely aligned with Christian values. ${ }^{38}$

Column (1) indicates a weak correlation between religiosity and conservatism on tax policy. In Column (2), we run the full differences-in-differences-in-differences specification. The most important variable is the triple interaction of the effect of Christian values for Swedish respondents after the 2000 abolition of the state church. This estimate has a significantly positive value, indicating that religious Swedes became more fiscally conservative after 2000. One standard deviation in Christian values corresponds to a shift in 0.16 greater support for cutting taxes after the Swedish reform,

\footnotetext{
${ }^{38}$ This question was only asked in the Norwegian data from 1997 onwards, reducing the length of the Norwegian part of the panel. Shortening the sample for Sweden to the same time period gives similar but less precise estimates than the ones presented in Table V.
} 
or $10 \%$ of a standard deviation in support for taxes. In Columns (3) and (4), we repeat similar estimations, but now include individual fixed effects. As there is little variation in a given respondents' reported importance of Christian values, it is difficult to get a meaningful estimate of the effect of a change in this variable as revealed by Column (3). However, when we look at the change in the state church regime in Column (4), it is again apparent that abolishing the state church made religious Swedes more fiscally conservative. Finally, in Column (5), we only look at the last election before and the first election after the 2000 abolition. We regress preferences expressed after the abolition on the answer to the same question expressed before the abolition, as well as the importance of Christian values expressed before the abolition, and this variable interacted with being Swedish. This indicates that Swedes with strong Christian values became more fiscally conservative than other respondents.

Columns (6) to (10) study the same specifications, but look instead at attitudes to inequality without specific attention given to government actions. Inequality attitudes are measured so that high values indicate a more liberal attitude, i.e. favor equality. From Column (6) we see that more religious respondents are more accepting of income differentials. However, this acceptance did not increase in Sweden after the state church abolition-instead, it decreased as we see from Column (7), meaning that religious Swedes preferred more equality but not through state intervention. Again, there is little to learn from changes in reported attitudes to Christian values (Column 8), but Column (9) confirms that, comparing within individuals over time, the abolition of the state church did not make religious Swedes more pro-inequality. Finally, looking at changes in preferences before and after the abolition in Column (10), the same pattern of increased inequality aversion for religious Swedes emerges although the results are not significant. ${ }^{39}$

\subsection{U.S. Supreme Court: Time-Series}

We now return to the puzzle of why the Social Gospel movement shifted to the religious right. A much-debated voting pattern is that religiosity has increasingly predicted Republican voting (Glaeser et al. 2005). However, this alignment has not always existed: the relationship between religious attendance and Republican voting was actually declining before 1976. Figure 7 displays, for each electoral vote, the regression coefficients from regressions of Republican voting on church attendance. In 1968, the association was roughly 0.017 , dipping to 0.005 in 1976, and increasing to its peak of 0.036 in $2004 .^{40}$

Students of U.S. history often assume that the U.S. always had church-state separation. According to legal scholars (Hamburger 2002, Feldman 2005), church-state separation was actually not read into the Constitution until the last century and they cite the case of the large number of Catholic immigrants to the U.S. in the late 19th century. Protestant Bible-reading in public schools triggered parents to send their children to Catholic private schools; they then argued that they were being doubly penalized in taxes for Protestant public schools and tuition for Catholic private schools. In response, there was a proposal to ban government funding of religious institutions in the 1870s. Before the welfare state, government support for the poor was often distributed through religious organizations. In fact, the secular movement promoting separation of church and state did not begin until the 1920s-in the U.S. by elites, and in Europe by non-elites.

\footnotetext{
${ }^{39}$ The World Value Survey also covers a period before and after the Swedish separation of church and state. Barro and McCleary code Sweden as having a state church. The results are similar if we recode to no state church after 2000. If we analyze only Swedish data in a before-after analysis, the estimates are imprecise, but have the same sign as in our voter panel analysis.

${ }^{40}$ Source is the General Social Survey. Coefficients are from OLS regressions of the dummy for republican vote on attendance, controlling for the same variables as in Table I.
} 


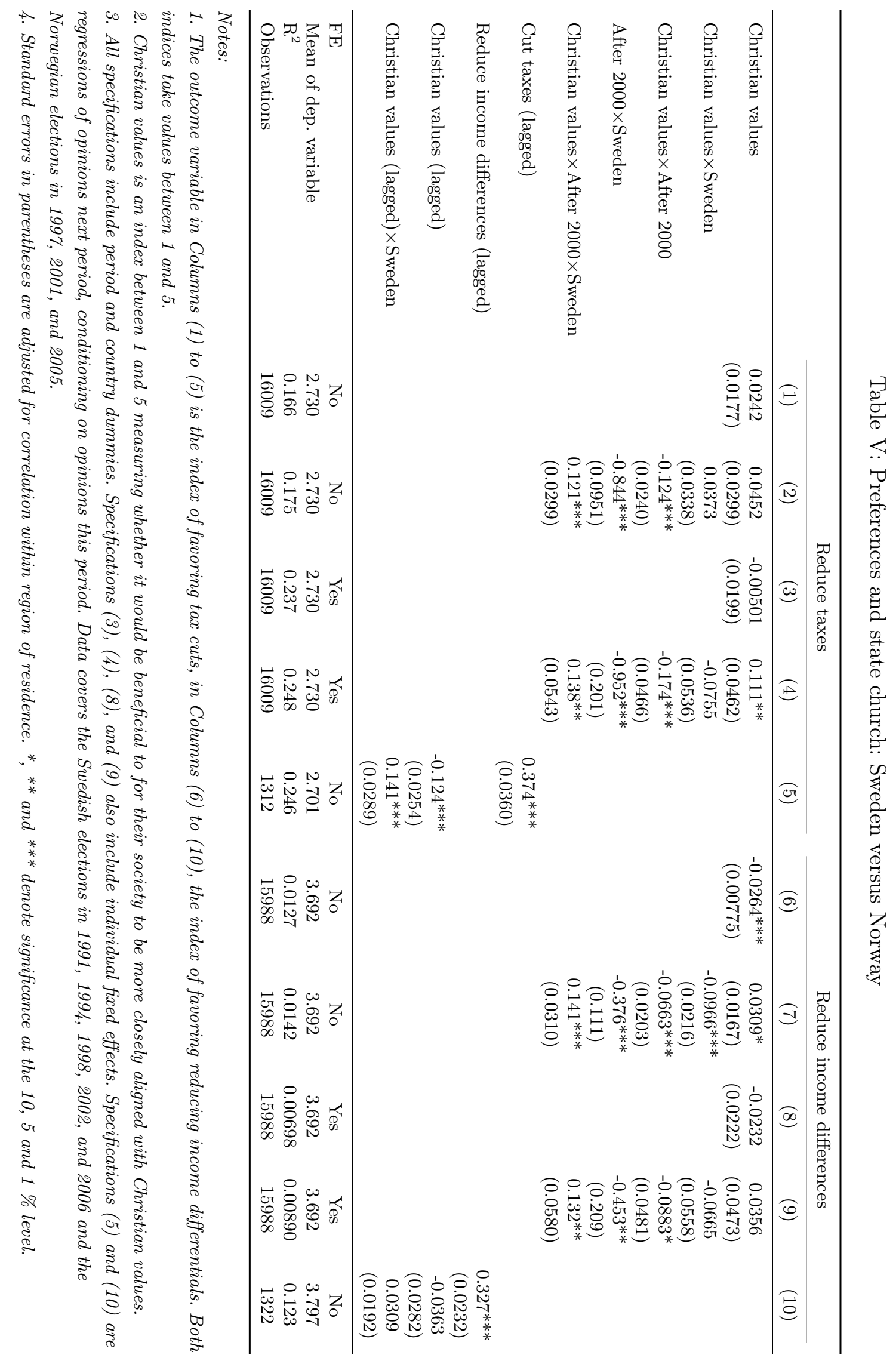


The previous sections showed an alignment between fiscal and social conservatism at the individual level within countries that appeared to be explained by a mechanism for social insurance as measured by within-group giving, and this alignment reversed for members of the state church. This section investigates whether that reversal can also be found across time within the U.S. as judicial decisions gradually separated church and state, and at different speeds in different time periods. To mitigate concerns that the cross-country test of church-state separation is driven by omitted country-level factors, we construct a time-series of church-state separation judicial decisions within the U.S.

The switch in the relationship between church attendance and Republican voting roughly coincided with judicial decisions on separation of church and state, which reached its highest rate during the 1970s and early 1980s (Figure 8). Figure 8 and Appendix Table XVIII document U.S. Supreme Court activity (where the Supreme Court either made a decision or let stand a lower court decision) on church-state separation in public schools. Figure 8 shows the number of decisions each year that increase or decrease separation of church and state.

These decisions include disallowing religious instruction in public schools (1948), disallowing prayer in public schools (1962), disallowing Bible recitation in public schools (1963), disallowing direct government assistance to religious schools (1971), disallowing tax deductions and reimbursements for children in religious schools (1973), disallowing display of the Ten Commandments (1980), ruling that the equal treatment of creation science and evolution is unconstitutional (1981), and disallowing graduation prayer (1992). The data in Appendix Table IX comes from About.com ${ }^{41}$ ("Supreme Court Decisions-Religion in Schools"), which draws from Hall and Ely Jr. (2009) and Alley (1988),(1999) Supreme Court decisions and Circuit Court decisions that were certiorari denied (appealed but let stand by the Supreme Court without hearing).

Figure 9 shows that increases in church-state separation precede increases in the strength of the relationship between church attendance and Republican voting. The x-axis marks the net number

\footnotetext{
${ }^{41}$ Downloaded in 2005.
}

Figure 7

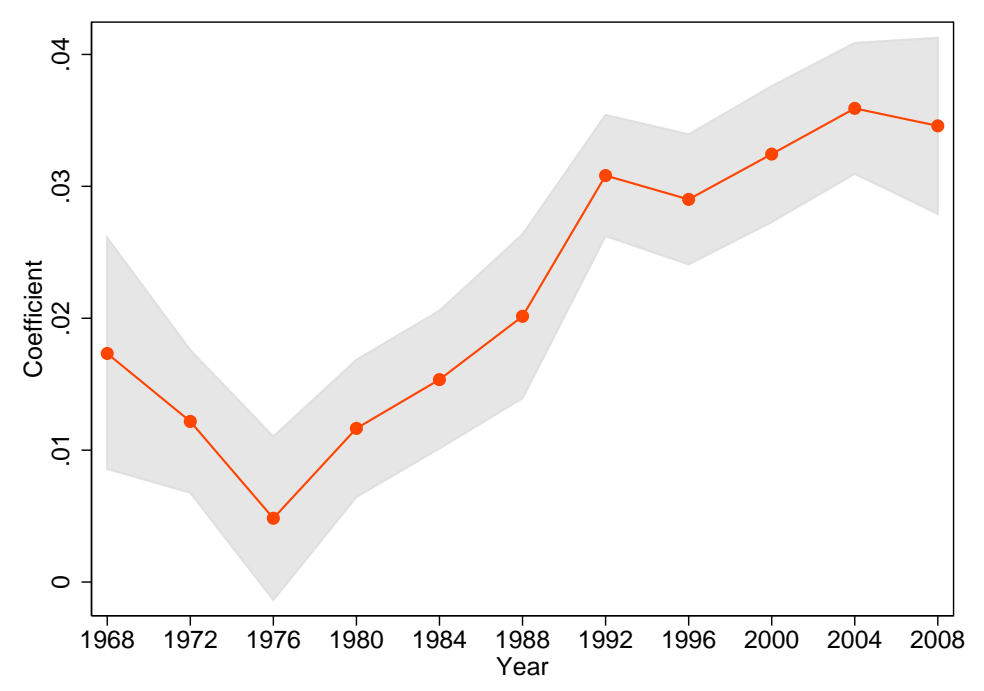

Notes: The graph shows the coefficient of church attendance on the probability of voting Republican by election year with $95 \%$ confidence intervals. 
of judicial decisions increasing or decreasing church-state separation in the four years prior to an election year. The y-axis marks the change in the coefficient on the relationship between church attendance and Republican voting. An OLS regression of the form

$$
\Delta \text { ChurchAttendance_RepublicanVoting }{ }_{t}=\beta_{o} \Delta \text { ChurchStateSeparation }{ }_{t}+\varepsilon_{t}
$$

yields an estimate of $\beta_{0}$ of $0.0027(0.0010)$, a positive relationship that is statistically significant at

\section{Figure 8}

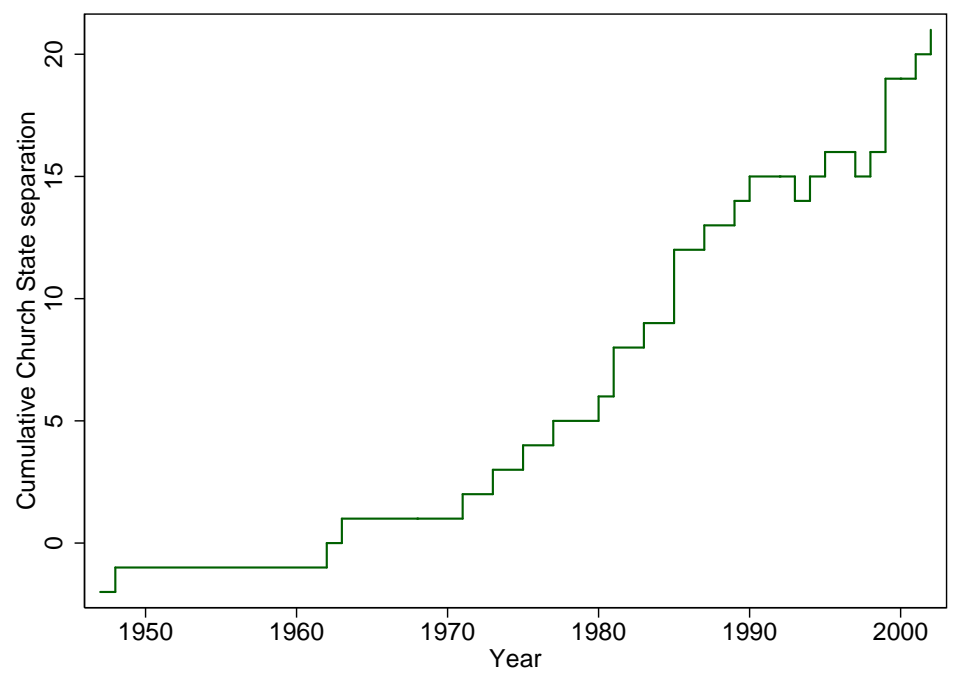

Notes:

1. The graåh shows the cumulative number of church state separations defined as the number of increases minus the number of decreases since $194 \%$.

2. See Appendix Table XVIII for a full list of the Supreme Court Decisions.

Figure 9

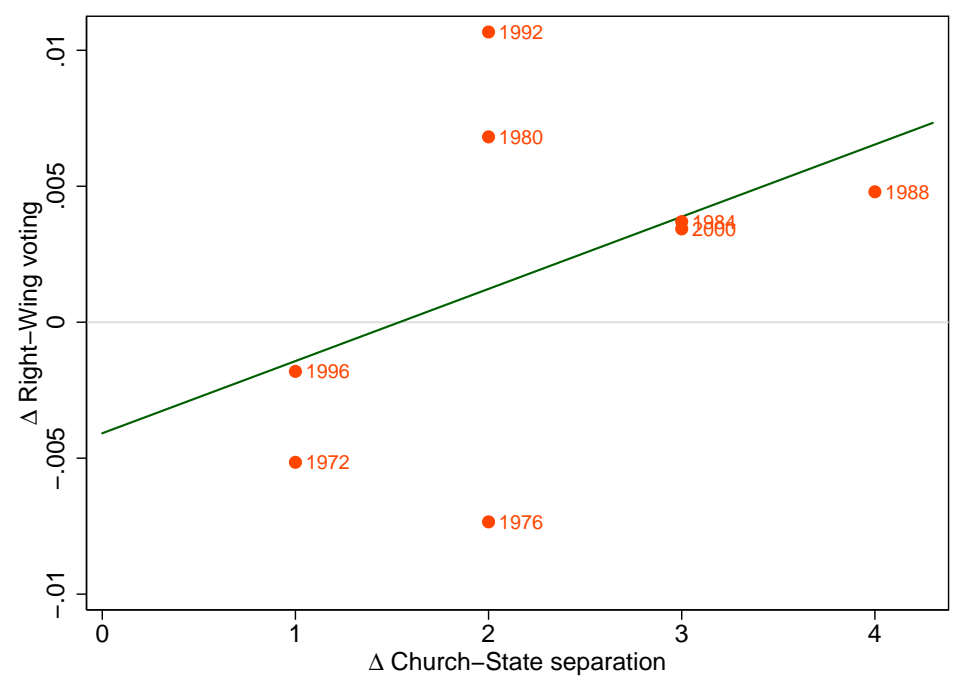


the $4 \%$ level. (An OLS regression of change in voting patterns on the following period's church-state separation decisions yields a coefficient of -0.0005 (0.003), a Granger causality test.)

This coefficient suggests 1 judicial decision increasing church-state separation would increase how strongly church attendance predicts Republican voting by 0.033 . To explain a shift in the coefficient between church attendance and Republican voting of 0.16 (0.01 in 1976 to 0.17 in 1992) would require roughly 4.8 judicial decisions. Given the number of judicial decisions increasing church-state separation since then ( 8 increasing, 3 decreasing), the vociferousness of the contemporary debate on religion and politics in recent years is to be expected.

\subsection{U.S. Circuit Courts: Random Variation}

\subsubsection{Institutional Background ${ }^{42}$}

A foundational understanding of the U.S. federal courts is important to understanding our identification strategy, which relies on the law-making function of common law courts. This making of law occurs because a judge's decisions in current cases become precedent for use in in future cases in the same court and in lower courts of the same jurisdiction. There are three layers of federal courts: District, Circuit, and the U.S. Supreme Court. The 94 U.S. District Courts serve as general trial courts in which a jury decides issues of facts. If a party appeals the decision, the case goes up to a Circuit Court, which decides issues of law; they take facts from District Courts and have no juries. The 12 U.S. Circuit Courts, also known as Courts of Appeals or federal appellate courts, only hear cases presenting new legal issues (only 10-20\% of District Court opinions are appealed). Cases that reach the Circuit Courts are the more challenging and controversial cases with the greatest likelihood to set new precedent. Figure 10 displays District Court boundaries in dotted lines and Circuit Court boundaries-encompassing between 5 and 13 Districts each-in solid lines. ${ }^{43}$

Figure 10

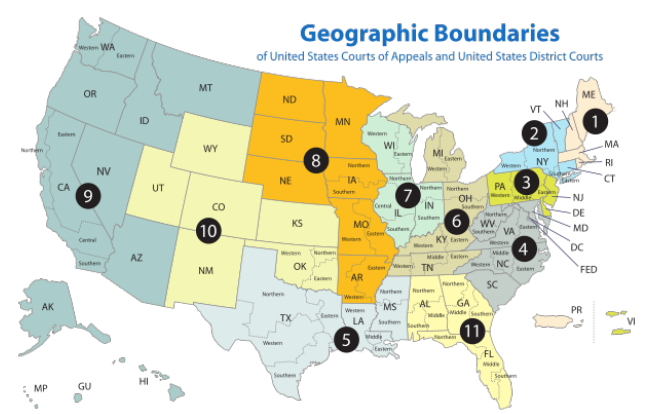

In deciding issues of law, Circuit Courts provide new interpretations or distinctions of pre-existing precedents or statutes. These new distinctions expand or contract the space under which an actor is found liable (Gennaioli and Shleifer 2007). Each Circuit Court decides many thousands of cases per year (about 1 case per Circuit per year is related to separation of church and state), but only $2 \%$ of Circuit cases successfully appeal to the U.S. Supreme Court, so Circuit Courts determine the vast majority of decisions each year that set legal precedent. Circuit Court decisions are binding precedent, but only within that Circuit. When Circuits choose to adopt the precedent of another Circuit, it is typically with some delay: before an opinion can be issued in the new Circuit, a case

\footnotetext{
${ }^{42}$ This material is largely quoted from Chen and Yeh (2014).

${ }^{43}$ The Federal Circuit Court does not have jurisdiction based on geography and handles mostly patent cases; therefore it is omitted from our study.
} 
bringing the same issue of law must be filed in a District Court, appealed to the Circuit Court, and decided upon. Circuit Court decisions are persuasive precedent on state courts within the Circuit. ${ }^{44}$

Each Circuit Court case receives three randomly assigned judges out of a pool, numbering roughly 8 to 40 depending on the size of the Circuit. These judges are appointed for life by the U.S. President and their positions and decisions are highly esteemed. ${ }^{45}$ State officials are instructed to establish and annually update a set of guidelines based on federal and state law to assist state agencies in identifying and analyzing actions that may result in a violation of legal precedent; they have reported adjusting their regulations to avoid exposure to costly litigation after Circuit Court decisions (Frost and Lindquist 2010; U.S. Department of Transportation, Federal Highway Administration 2005; Pollak 2001). Newspapers, advocates, and community organizers highlight the change in legal landscape after Circuit Court decisions (Pastor 2007; Eagle 2007; Sandefur 2005). Since judges follow precedent (Chen et al. 2014a) and markets respond to Circuit Court decisions (Araiza et al. 2014), we might expect to see an effect of Circuit Court decisions on social outcomes.

We code all Establishment Clause precedent from 1964-2011 following the methodology established in Sunstein et al. (2006). We select all 1,147 Circuit Court cases mentioning the Establishment Clause. We then restrict to three-judge cases that were substantively about church-state separation, resulting in 820 cases. We compiled information on judge characteristics from the Appeals Court Attribute Data, District Court Attribute Data, ${ }^{46}$ Federal Judicial Center, and data collection reported in Chen and Yeh (2014). To illustrate the identification strategy, Figure 11 shows that excess variation in Democratic judges is random.

Figure 11: Random Variation by Circuit

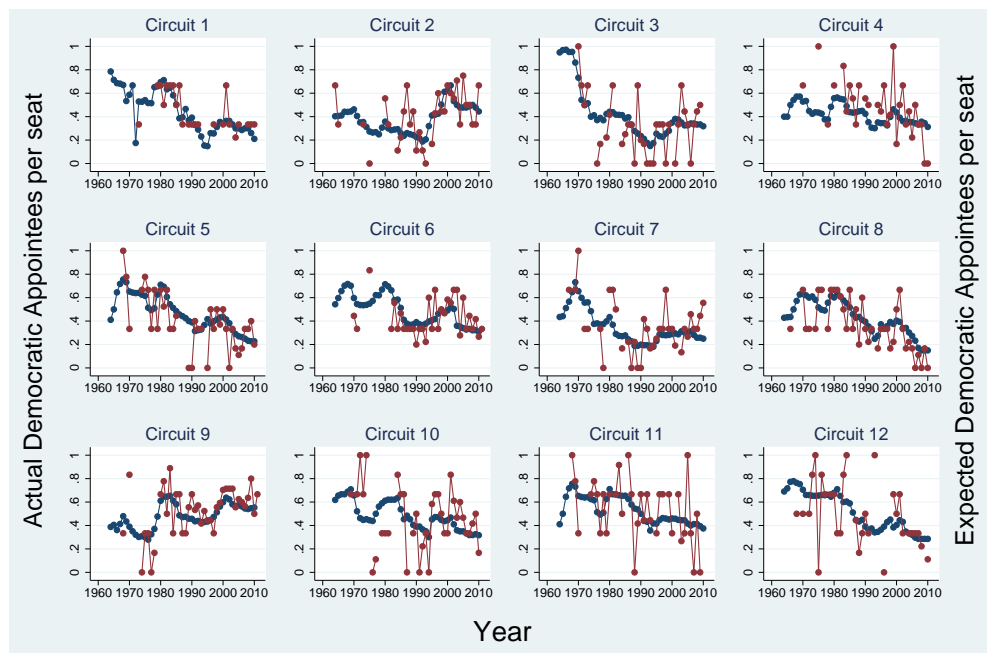

Notes: For each Circuit, we display the Expected proportion of judge seats that would be assigned to Democrats in blue. The actual proportion of judge seats assigned to Democrats is in red.

\footnotetext{
${ }^{44}$ Persuasive precedent must be adopted by the state courts to become binding precedent. State courts have a similar heirarchy: district courts, appellate courts, and supreme courts; and an appeal from the state supreme court goes to the U.S. Supreme Court.

${ }^{45}$ Except for retirement, Circuit judges typically leave the bench only for a position in the U.S. Supreme Court.

${ }^{46}$ http://www.cas.sc.edu/poli/juri/attributes.html
} 


\subsubsection{Estimation}

We seek to estimate whether the relationship between church-state separation and religious-right Republican alignment is causal. Our structural specification is a distributed lag:

$$
\begin{aligned}
& Y_{i c t}=\beta_{0}+\sum_{n} \beta_{1 n} L a w_{c(t-n)}+\sum_{n} \beta_{2 n} \mathbf{1}\left[\mathrm{M}_{\mathrm{c}(\mathrm{t}-\mathrm{n})}>0\right]+\beta_{3} C_{c}+\beta_{4} T_{t}+\beta_{5} C_{c} * \text { Time } \\
& +\sum_{n} \beta_{6} W_{c(t-n)}+\beta_{7} X_{i c t}+\varepsilon_{i c t}
\end{aligned}
$$

Strong self-identity as a Republican is the dependent variable, $Y_{i c t}$ for individual $i$ in Circuit $c$ and year $t$. We estimate a distributed lag effects of $L a w_{c t}$, which is the percentage of cases in a Circuityear that voted to separate church and state. Many Circuit-years do not have decisions, so we define $L a w_{c t}$ to be 0 when there are no cases and introduce a dummy, $\mathbf{1}\left[M_{c t}>0\right]$, for presence of an appeal. We then interact $L a w_{c(t-n)}$ and $\mathbf{1}\left[\mathrm{M}_{\mathrm{c}(\mathrm{t}-\mathrm{n})}>0\right]$ with Fundamentalism, so we can observe whether church-state separation precedent caused Fundamentalists to strongly self-identify as Republican. We report $\frac{\sum_{n} \beta_{1 n}}{n}$ and joint significance of the lag interaction coefficients. ${ }^{47}$

We have a combinatorial number of biographical characteristics that serve as valid instruments. We use LASSO (least absolute shrinkage and selection operator) to select instruments (Belloni et al. 2012). ${ }^{48}$ To construct our potential LASSO instruments, we use 30 biographical characteristics ${ }^{49}$ and their interactions at the judge level ${ }^{50}$ and panel level ${ }^{51}$ yielding a total of 900 possible instruments. See Chen and Yeh (2014) for further detail.

Both the OLS and IV estimates indicate that after legal precedent separating church and state, fundamentalists began identifying more strongly as Republican in the 4 years after a decision. No reverse causality is observed as the lead coefficients are insignificant. ${ }^{52}$

\footnotetext{
${ }^{47}$ Litigants' decisions to appeal may be in response to previous years' legal decisions, however, so controlling for $\mathbf{1}\left[M_{c t}>0\right]$ will bias $L a w_{c t}$; the bias is more severe for more distant lags and non-existent for the most advanced lead. We use random assignment of District Court judges to identify $\mathbf{1}\left[M_{c t}>0\right]$ : District judge demographic characteristics are correlated with reversal rates (Haire, Songer, and Lindquist 2003; Sen 2011; Barondes 2010; Steinbuch 2009); and expected reversal rates could encourage litigants from pursuing an appeal. Once we use instruments to identify both $\mathbf{1}\left[M_{c t}>0\right]$ and $L a w_{c t}$, estimates should be roughly invariant to the inclusion or exclusion of additional lags and leads. Including lags that are important predictors of the outcome improves statistical precision, but losing data at the beginning and end of the time period reduces precision. The use of leads serves as an important omnibus check of our instrumental variable. We show average lag and lead effects to assess the degree to which violation of random variation biases our estimates.

${ }^{48}$ Intuitively, LASSO has two properties that OLS lacks: sparseness and continuity. With OLS, large subsets of covariates are deemed important, resulting in too many instruments, which makes 2SLS susceptible to a weak instruments problem. Small changes in the data often results in different subsets of covariates deemed important. Formally, LASSO modifies OLS by adding a data penalty for having too many large coefficients. The model minimizes the sum of squares subject to the sum of the absolute value of the coefficients being less than a constant, which tends to set some coefficients to exactly 0 and hence reduces model complexity.

${ }^{49}$ Democrat, male, male Democrat, female Republican, minority, black, Jewish, Catholic, No religion, Mainline Protestant, Evangelical, bachelor's degree (BA) received from same state of appointment, BA from a public institution, JD from a public institution, having an LLM or SJD, elevated from District Court, decade of birth (1910s, 1920s, 1930s, 1940s, or 1950s), appointed when the President and Congress majority were from the same party, ABA score, above median wealth, appointed by president from an opposing party, prior federal judiciary experience, prior law professor, prior government experience, previous assistant U.S. attorney, and previous U.S. attorney.

${ }^{50}$ For example, the number of racial minority Democrats per seat.

${ }^{51}$ For example, the number of Democrats per seat multiplied by the number of racial minority judges per seat.

${ }^{52}$ Welfare support is not significantly affected as an outcome variable. One possible reason is that "Strong Republican" may convey a stronger signal than a question about "too much / too little".
} 


\section{MULTIPLE STEADY STATES}

\subsection{Religious Attendance, Church-State Separation, and Welfare State}

The ideal experiment to test for multiple steady states would temporarily shock parameter values to see if countries shift from one steady-state basin of attraction to another. In its absence, we report that, on average, some countries sustain high religiosity, high church-state separation, and low welfare state, whereas others sustain low religiosity, low church-state separation, and high welfare state in a larger sample than previous research (Barro and McCleary 2005). Religious attendance is higher in countries without a state church (Table 8). $26 \%$ of respondents in countries with a state church attend monthly while $38 \%$ of respondents in countries without a state church attend monthly. This correlation has also been documented by Finke and Stark (1992), Iannaccone (1998), and Barro and McCleary (2005); for cross-country negative correlations between religiosity and size of welfare state, see Gill and Lundsgaarde (2004), Scheve and Stasavage (2006), and Cavanaugh (2005).

\subsection{Historical Interpretation}

We have found that fiscal and social conservatives and fiscal and social liberals tend to come hand-in-hand in countries without a state church. In these countries, the welfare state crowds out religious insurance. Religious individuals are fiscal conservatives because larger insurance groups enable greater smoothing. Following Coate and Ravallion (1993), Kocherlakota (1996), Alvarez and Jermann (2000), Krueger and Perri (2002), and Genicot and Ray (2003): risk-sharing mechanisms are self-sustaining because agents are punished with permanent autarky if they choose to defect. So, religious groups with greater within-group giving are more against the welfare state and more socially conservative, which can be interpreted as punishment against out-groups. In this sense, social insurance in religious groups helps complete a missing market for credit.

In countries with a state church, the alignment reverses: social conservatives become fiscal liberals. With less church-state separation, taxes contribute to the insurance mechanism of religious groups. We apply this framework to explain the changing nature of religious movements. In the U.S., the Social Gospel movement was a Protestant Christian intellectual movement prominent in the early 20th century that applied Christian ethics to social problems, such as economic inequality (Fogel

2000). Prohibition, the constitutional ban on alcohol, was also attributable to the Social Gospel

TABLE VI

Fiscal and Social Conservatism/Liberalism and Church-State Separation within the U.S.

\begin{tabular}{lcccc}
\hline & & & & $\begin{array}{c}\text { Dependent } \\
\text { Panel A }\end{array}$ \\
Average Interaction Lag Effect & $\begin{array}{c}\text { OLS } \\
\text { LASSO IV }\end{array}$ & $\begin{array}{c}\text { Obs } \\
(2)\end{array}$ & $\begin{array}{c}(3) \\
(4)\end{array}$ \\
\cline { 2 - 5 } Identify as Strong Republican & 0.004 & 0.009 & 42837 & 0.098 \\
Joint P-value & 0.057 & 0.000 & & \\
\hline Panel B & & & & \\
Average Interaction Lead Effect & & & & \\
Identify as Strong Republican & 0.006 & 0.024 & 42837 & 0.098 \\
Joint P-value & 0.260 & 0.291 & & \\
\hline
\end{tabular}

Notes: Interaction with Fundamentalism. Regressions include level effects, circuit fixed effects, year fixed effects, a dummy for whether there were no cases in that circuit-year. 
movement. This pattern is consistent with social conservatives being fiscal liberals.

While the exact reason for decline in the Social Gospel movement is debatable, most scholars agree that it peaked in the early 20th century. The rise of the Religious Right began in the 1940s and has been especially influential in U.S. political discourse since the 1970s. Why would the Social Gospel movement be replaced by a religious movement rejecting the welfare state? The development of credit markets provides one answer. In most countries, elites gain access to credit markets first. ${ }^{53}$ Thus, they desire a lower tax burden (Acemoglu and Robinson 2000). In our model, they have incentives to adjudiciate increasing church-state separation, which creates a constituency for lower taxes. This holds only if religious voters exceed non-religious voters. Otherwise, elites prefer a state church to curb the secular left, which is consistent with many European countries with low religiosity and large state churches.

As the welfare state shrinks, religiosity increases because the marginal person seeking insurance turns to religion instead. Countries with high initial parameters for religiosity, like the U.S., increase church-state separation. Preferences of religious groups shift to the Religious Right, but as the welfare state shrinks, individuals become more religious, which increases the incentives for elites to separate church and state, creating a positive feedback. Countries like the U.S. sustain high religiosity, high church-state separation, and low welfare state.

Countries with low initial parameters for religiosity, like those in Europe, increase the state church, which curbs the demand for welfare by non-religious groups. However, if they successfully shrink the welfare state, individuals become more religious, which undermines the initial low religious weight, creating a negative feedback. This implies a stable steady state with a large welfare state, large state church, and low religiosity.

Countries can also permanently shift from one steady state to another with temporary shifts in credit availability, which suggests a counter-intuitive policy application. Economic sanctions may increase theocratic tendencies in countries with large religious populations if elites are restricted from international capital markets and lose access to alternative social insurance. In this case, the

\footnotetext{
${ }^{53}$ Non-elites are frequently excluded from credit and insurance markets (Banerjee et al. 2006).
}

TABLE VII

Church attendance in COUntries With And Without a STATE CHURCh

\begin{tabular}{lc}
\hline & Fraction with at least monthly attendance \\
\hline Countries with state church & $0.425^{* * *}$ \\
& $(10.26)$ \\
Countries without state church & $0.465^{* * *}$ \\
& $(11.10)$ \\
\hline Difference & -0.0404 \\
& $(-0.69)$ \\
\hline$N$ & 238981 \\
\hline
\end{tabular}

Notes:

1. Data are from World Values Survey cumulative file, waves 1-5. Standard errors in parentheses are adjusted for correlation within country of residence. *, ** and *** denote significance at the 10, 5 and $1 \%$ level. 2. Data on church-state separation from Barro and McCleary (2005), which is based on Barrett (1982) and Barrett et al. (2001). They classify countries as having a state religion if the constitution designates an official state church and restricts or prohibits other forms of religion, or, if the government merely systematically favors a specified religion through subsidies and tax collection or through the teaching of religion in public school. 
story reverses: elites decrease church-state separation if religious voters exceed non-religious ones. Preferences for redistribution are high and social insurance by religious groups completes a missing market for credit. ${ }^{54}$

Using Barro and McCleary's (2005) data on church-state separation in 1900, 1970, and 2000, and the founding date of the stock market in each country, we find some evidence consistent with this hypothesis. Of the 53 countries that had no state church in 1900 and 1970, the average founding year was 1928. Of the 65 countries that had a state church in both 1900 and 1970, the average founding year was 1956. Of the 30 countries that had a state church in 1900 but separated it by 1970, the average founding year was 1953. Of the 3 countries that had no state church in 1900 but began a state church by 1970, the average founding year was 1950 .

Between 1970 and 2000, of the 9 countries that had no state church in 1970 but began a state church by 2000, the average founding year of their stock market was 1988 . Of the 7 countries that had a state church in 1970 but separated it by 2000, the average founding year was 1952 . Of the 61 countries that had a state church in bot h 1970 and 2000, the average founding year was 1956. Of the 74 countries that had no state church in 1970 and 2000, the average founding year was 1931. These data indicate that countries that had earlier stock market development were less likely to have a state church.

\subsection{Alternative Theories}

Existing work on the decline of the Social Gospel movement and the rise of the Religious Right tend to be descriptive (Carter 1956; Bateman 1998). Hood et al. (2005) and Woodberry and Smith (1998) detail how conservative groups associated with the Social Gospel movement withdrew from society in the 1940s and eventually formed branches currently classified as fundamentalist (Hood et al. 2005) and Evangelical (Hubbard 1991), with a defining characteristic of both groups being the importance of the proper interpretation of the Christian Bible. Traditionalist factions within the evangelical movement rejected the progressivism of the Social Gospel (Midgley 1990).

To the extent there are explanations for the changing nature of religious movements, scholars variously cite the growth of religious pluralism, the acceptance of scientific findings, the rapid increase in urbanization, new forms of media, and the Cold War. Others argue that the Social Gospel declined because of the World Wars and Prohibition. Still others argue that Roe v. Wade caused religious liberals to join conservatives. While these social trends may explain some of the patterns we observe, the alignment we see today between fiscal and social conservatism occurs in many countries, not all of which had important constitutional moments like Roe v. Wade. And, countries where this alignment is reversed also experienced the Cold War and scientific development.

Theories about church-state separation also tend to be descriptive, the one exception being the view that richer countries are less likely to have a state religion. This theory clearly fails to explain European countries becoming richer but not dismantling their state religions. Another explanation attributes the lack of separation of church and state in much of western Europe to the general statist nature of these countries (van Bijsterveld 2000). This explanation runs counter to Feldman and Hamburger's reading of the legal record of the U.S. as not having separation in the past, since the U.S. is relatively non-statist. According to their reading, "the concept of separation achieved prominence in the nineteenth century, in large part, because of nativist fears of immigration from Catholic lands and the growing authority of the Roman Catholic Church. Proponents of separation, through either ignorance or hypocrisy, claimed a historical pedigree for separation that simply did

\footnotetext{
${ }^{54}$ Certainly, some countries are exceptions to our theory. Many formerly Communist countries have had elites who can disregard the voting preferences of the poor.
} 
not exist. Most of them indefensibly envisioned separation as circumscribing Catholic power without impeding Protestant connections between religion and government." Hamburger (2009).

Consistent with this view, Barro and McCleary (2006) use a Hotelling model to argue that the greater concentration of religious adherence, the more likely for there to be a state religion. Others state that the separation between state and religion in the U.S. is due to the presence of religious diversity (Kuru 2007); yet, some European countries have a large Muslim minority and have not separated church and state.

\section{CONCLUSION}

Religious intensity as social insurance may explain why fiscal and social conservatives and fiscal and social liberals come hand-in-hand. Some argue that depending on the welfare state is the same as worshipping the government as if it were God. While theory predicts political positions will map along a single axis (DeMarzo et al. 2003), no obvious theory explains why political alignments exist along this diagonal. Government welfare crowds out church participation and charitable provision (Gruber and Hungerman 2007).

We present new evidence that fiscal and social conservatism and fiscal and social liberalism are correlated at the individual level within countries, religious groups with greater within-group giving are more against the welfare state and more socially conservative, and individuals participating more in religious groups with greater within-group giving are more against the welfare state. The relationship between fiscal and social attitudes is reversed for members of the state church.

This reversal is unlikely to be driven by omitted environmental variables. Separation of church and state precede alignment between fiscal and social conservatism using three quasi-experiments: the 2000 Swedish separation of church and state, decisions in the U.S. Supreme Court, and random jurisprudential variation in U.S. Circuit Courts where judges are randomly assigned.

We build a simple model that provides a novel explanation for the changing nature of religious movements, from Social Gospel (social conservatives - fiscal liberals) to the Religious Right (social conservatives - fiscal conservatives). Our model gives rise to multiple steady states and helps explain why church-state separation arose in the U.S. but not in Europe, where religiosity has historically been lower than in the U.S. We show that church-state separation and monthly religious attendance are highly correlated across countries with expanded data.

We hypothesize that fundamentalism can persist because optimal insurance may be a substantial fraction of wages (Chetty 2004), and insurance provision by religious groups may fill a missing market for credit. We apply this framework to shed light on the dynamics of credit market access, theocracy, and fundamentalism in developing and reconstructing war-torn countries. 


\section{REFERENCES}

Acemoglu, D. And J. A. Robinson (2000): "Why Did The West Extend The Franchise? Democracy, Inequality, And Growth In Historical Perspective," The Quarterly Journal of Economics, 115, 1167-1199.

Alley, R. S. (1988): The Supreme Court on Church and State, Oxford University Press.

(1999): The Constitution 8 Religion: Leading Supreme Court Cases on Church and State, Prometheus Books.

Alvarez, F. And U. J. Jermann (2000): "Efficiency, Equilibrium, and Asset Pricing with Risk of Default," Econometrica, 68, 775-797.

Ansolabehere, S., J. Rodden, And J. M. S. JR. (2006): "Purple America," The Journal of Economic Perspectives, $20,97-118$.

Araiza, A. G., D. L. Chen, And S. Yeh (2014): "Does Appellate Precedent Matter? Stock Price Responses to Appellate Court Decisions on FCC Actions," in Empirical Legal Analysis: Assessing the Performance of Legal Institutions, ed. by Y. chien Chang, Routledge, vol. 19 of Economics of Legal Relationships.

Banerjee, A. V., R. BÉabou, and D. Mookherjee (2006): "Introduction and Overview," in Understanding Poverty, ed. by A. V. Banerjee, R. Béabou, and D. Mookherjee, New York: Oxford University Press.

Barondes, R. D. R. (2010): "Federal District Judge Gender and Reversals," in 5th Annual Conference on Empirical Legal Studies Paper, Working Paper.

Barrett, D. B. (1982): World Christian Encyclopedia, Oxford University Press, 1 ed.

Barrett, D. B., G. T. Kurian, And T. M. Johnson (2001): World Christian Encyclopedia: A Comparative Survey of Churches and Religions in the Modern World, World Christian Encyclopedia: A Comparative Survey of Churches and Religions in the Modern World, Oxford University Press, 2 ed.

Barro, R. J. And R. M. MCCleary (2005): "Which Countries Have State Religions?" Quarterly Journal of Economics, 120, 1331-1370.

Bateman, B. W. (1998): "Clearing the Ground: The Demise of the Social Gospel Movement and the Rise of Neoclassicism in American Economics," in The Transformation of American Economics: From Interwar Pluralism to Postwar Neoclassicism, Mary S. Morgan and Malcolm Rutherford, vol. 30 of History of Political Economy Annual Supplement, $29-52$.

Belloni, A., D. L. Chen, V. Chernozhukov, and C. Hansen (2012): "Sparse Models and Methods for Optimal Instruments with an Application to Eminent Domain," Econometrica, 80, 2369-2429.

Berman, E. (2000): "Sect, Subsidy, and Sacrifice: An Economist's View of Ultra-Orthodox Jews," The Quarterly Journal of Economics, 115, 905-953.

Biddle, J. (1992): "Religious Organizations," in Who Benefits from the Nonprofit Sector?, ed. by C. T. Clotfelter, University of Chicago Press.

Brohed, I. (2005): Sveriges kyrkohistoria. Religionsfrihtens och ekumenikens tid, vol. 8, Stockholm: Verbum.

Cadge, W. and R. Wuthnow (2006): "Religion and the Nonprofit Sector," in The Nonprofit Sector: A Research Handbook, ed. by W. W. Powell and R. Steinberg, Yale University Press, chap. Religion and the Nonprofit Sector, 485-505, 2 ed.

Carter, P. A. (1956): The Decline and Revival of the Social Gospel: Social and Political Liberalism in American Protestant Churches, 1920-1940, Cornell University Press.

Cavanaugh, J. M. (2005): "Unholy Alliance or a Match Made in Heaven? Welfare State Outcomes, the Economics of Religion, and the Logic of Conservative Political Coalitions," Working paper, University of Illinois at UrbanaChampaign Mimeo, presented at the Fourth Annual Meeting of the Association for the Study of Religion, Economics, and Culture, Rochester, NY Nov. 4-6, 2005.

Chaves, M., S. Anderson, And J. Byassee (2009): "American Congregations at the Beginning of the 21st Century," National Congregations Study Report.

Chen, D. L. (2004): "Gender Violence and the Price of Virginity: Theory and Evidence of Incomplete Marriage Contracts," Working paper, University of Chicago, Mimeo.

(2006): "Islamic Resurgence and Social Violence During the Indonesian Financial Crisis," in Institutions and Norms in Economic Development, ed. by M. Gradstein and K. A. Konrad, MIT Press, chap. 8, $179-199$.

(2010): "Club Goods and Group Identity: Evidence from Islamic Resurgence during the Indonesian Financial Crisis," The Journal of Political Economy, 118, 300-354.

- (2012): "Markets and Morality: How Does Competition Affect Moral Judgment," Working paper, Duke University School of Law.

(2014): "Can Markets Stimulate Rights? On the Alienability of Legal Claims," Tech. rep.

Chen, D. L., J. Frankenreiter, And S. Yeh (2014a): "Development of Law and Corporate Malfeasance," Tech. rep., ETH Zurich.

Chen, D. L. And Y. Givati (2014): "Can Markets Overcome Repugnance? Muslim Trade Reponse to AntiMuhammad Cartoons," Working paper, ETH Zurich, Mimeo.

Chen, D. L., V. Levonyan, S. E. Reinhart, and G. B. Taksler (2014b): "Mandatory Disclosure: Theory and 
Evidence from Industry-Physician Relationships," Working paper, mimeo.

Chen, D. L. And S. YeH (2014): "The Construction of Morals," Journal of Economic Behavior and Organization, 104, 84-105.

Chen, Y. And S. X. Li (2009): "Group Identity and Social Preferences," The American Economic Review, 99, 431-457.

Chetty, R. (2004): "Consumption Commitments, Unemployment Durations, and Local Risk Aversion," Working Paper No. 10211 10211, National Bureau of Economic Research.

Clingingsmith, D., A. I. Khwaja, And M. Kremer (2009): "Estimating the Impact of The Hajj: Religion and Tolerance in Islam's Global Gathering," The Quarterly Journal of Economics, 124, 1133-1170.

CnaAn, R. A., S. C. Boddie, F. Handy, G. Yancey, and R. Schneider (2002): The Invisible Caring Hand: American Congregations and the Provision of Welfare, New York University Press.

Coate, S. And M. Ravallion (1993): "Reciprocity without Commitment: Characterization and Performance of Informal Insurance Arrangements," Journal of Developmental Economics, 40, 1-24.

Converse, P. E. (1964): "The Nature of Belief Systems in Mass Publics," in Ideology and Discontent, ed. by D. E. Apter, Free Press of Glencoe, chap. The Nature of Beliefs Systems in Mass Publics, 342.

Dehejia, R., T. DeLeire, And E. F. P. Luttmer (2005): "Insuring Consumption and Happiness Through Religious Organizations," Working Paper 11576, National Bureau of Economic Research.

DeMarzo, P. M., D. Vayanos, and J. Zwiebel (2003): "Persuasion Bias, Social Influence, and Unidimensional Opinions," The Quarterly Journal of Economics, 118, 909-968.

EAGLe, S. J. (2007): "Does Blight Really Justify Condemnation?" Urban Lawyer, 39, 833-858.

Edlund, L. And R. Pande (2002): "Why Have Women Become Left-Wing? The Political Gender Gap and the Decline in Marriage," The Quarterly Journal of Economics, 117, 917-961.

Ekströм, S. (2003): Makten över kyrkan. Om Svenska kyrkan, folket och staten, Stocholm: Verbum.

Ellison, C. And L. K.George (1994): "Religious Involvement, Social Ties, and Social Support in a Southestern Community," Journal forthe Scientific Study of Religion, 33, 46-61.

Ellsworth, L. (1989): "Mutual Insurance and Non-Market Transactions Among Farmers in Burkina Faso," Unpublished ph.d. thesis, University of Wisconsin.

Fafchamps, M. (2004): Rural Poverty, Risk, and Development, Edward Elgar Publishing, Inc.

Feldman, N. (2005): Divided by God: America's Church-State Problem-and What We Should Do about it, Farrar, Straus and Giroux.

Fernandez, P., E. S. Purcell, K. Rinear, and R. Wiesinger (2003): God, Government, and the Road to Tyranny, Xulon Press.

Finke, R. And B. J. Grim (2006): "International Religion Indexes: Government Regulation, Government Favoritism, and Social Regulation of Religion," Interdisciplinary Journal of Research on Religion, 2, 1-40.

Finke, R. And R. Stark (1992): The Churching of America, 1776-1990: Winners and Losers in Our Religious Economy, Rutgers University Press.

Fiorina, M. P., S. J. Abrams, and J. C. Pope (2011): Culture War?: The Myth of a Polarized America, Great questions in politics series, Pearson.

Fogel, R. W. (2000): The Fourth Great Awakening and the Future of Egalitarianism, Morality and Society Series, University of Chicago Press.

Fox, J. (2008): A World Survey of Religion and the State, Cambridge University Press.

- (2011): "Building Composite Measures of Religion and State," Interdisciplinary Journal of Research on Religion, 7 , Article 8.

Frost, A. And S. Lindquist (2010): "Countering the Majoritarian Difficulty," Virginia Law Review, 96, 719-797.

Genicot, G. And D. Ray (2003): "Group Formation in Risk-Sharing Arrangements," Review of Economic Studies, $70,87-113$.

Gennaioli, N. And A. Shleifer (2007): "The Evolution of Common Law," The Journal of Political Economy, 115, 43-68.

Gill, A. And E. Lundsgandde (2004): "State Welfare Spending and Religiosity: A Cross-National Analysis," Rationality and Society, 16, 399-436.

Glaeser, E. L., G. A. M. Ponzetto, and J. M. Shapiro (2005): "Strategic Extremism: Why Republicans and Democrats Divide on Religious Values," The Quarterly Journal of Economics, 120, 1283-1330.

Glaeser, E. L. And J. Scheinkman (1998): "Neither a Borrower Nor a Lender Be: An Economic Analysis of Interest Restrictions and Usury Laws," Journal of Law and Economics, 41, 1-36.

Gruber, J. And D. M. Hungerman (2007): "Faith-Based Charity and Crowd-Out During the Great Depression," Journal of Public Economics, 91, 1043-1069.

Gustafsson, G. (2003): "Church-state separation Swedish-style," West European Politics, 26, 51-72.

Haire, S. B., D. R. Songer, And S. A. Lindquist (2003): "Appellate Court Supervision in the Federal Judiciary: A Hierarchical Perspective," Law $\&$ Society Review, 37, 143-168. 
Hall, K. L. (1999): The Oxford Guide to United States Supreme Court Decisions, Oxford University Press.

Hall, K. L. And J. W. Ely JR. (2009): The Oxford Guide to United States Supreme Court Decisions, Oxford University Press.

Hamburger, P. (2002): Separation of Church and State, Harvard University Press.

- (2009): Separation of Church and State, Harvard University Press, 4 ed.

Hirschman, A. O. (1982): "Rival Interpretations of Market Society: Civilizing, Destructive, or Feeble?" Journal of Economic Literature, 20, 1463-1484.

Hood, R. W., P. C. Hill, And W. P. Williamson (2005): The Psychology of Religious Fundamentalism, The Guilford Press.

Hornberger, J. (1993): "Serfs on the Plantation, Part 4," Freedom Daily, 1.

Hubbard, D. A. (1991): What We Evangelicals Belive, Fuller Seminary Press.

Hungerman, D. M. (2005): "Are Church and State Substitutes? Evidence from the 1996 Welfare Reform," Journal of Public Economics, 89, 2245-2267.

Iannaccone, L. R. (1992): "Sacrifice and Stigma: Reducing Free-Riding in Cults, Communes, and Other Collectives," Journal of Political Economy, 100, 271-291.

(1998): "Introduction to the Economics of Religion," Journal of Economic Literature, 36, 1465-1496.

Jost, J. T., J. Glaser, A. W. Kruglanski, and F. J. Sulloway (2003): "Political Conservatism as Motivated Social Cognition," Psychological Bulletin, 129, 339-375.

Keith T. Poole, H. R. (1997): Congress: A Political-Economic History of Roll Call Voting, Oxford University Press.

Kling, J. R., J. B. Liebman, L. F. Katz, and L. Sanbonmatsu (2004): "Moving to Opportunity and Tranquility: Neighborhood Effects on Adult Economic Self-Sufficiency and Health from a Randomized Housing Voucher Experiment," KSG Working Paper No. RWP04-035.

Kocherlakota, N. R. (1996): "Implications of Efficient Risk Sharing without Commitment," Review of Economic Studies, 63, 595-609.

Krueger, D. And F. Perri (2002): "Does Income Inequality Lead to Consumption Inequality? Evidence and Theory," Review of Economic Studies, 73, 163-193.

Kuru, A. T. (2007): "Passive and Assertive Secularism: Historical Conditions, Ideological Struggles, and State Policies toward Religion," World of Politics, 59, 568-594.

Landau, D. (1993): Piety and Power, the World of Jewish Fundamentalism, Hill and Wang.

Layman, G. (2001): The Great Divide: Religious and Cultural Conflict in American Party Politics, Power, Conflict, and Democracy : American Politics into the Twenty-First Century, Columbia University Press.

Ligon, E. (1994): "The Development and Use of a Consistent Income Measure for the General Social Survey," GSS Methodological Report 64, NORC, University of Chicago.

Lind, J. T. (2005): "Why is There so Little Redistribution?" Nordic Journal of Political Economy, 31, 111-125.

LizzA, R. (2005): "God's Politics': The Religious Left," The New York Times.

Maton, K. I. (1987): "Patterns and Psychological Correlates of Material Support Within a Religious Setting: The Biderectional Support Hypothesis," American Journal of Community Psychology, 15, 185-207.

McCleary, R. M. And R. Barro (2006): "Religion and Political Economy in an International Panel," Journal for the Scientific Study of Religion, June.

Meltzer, A. H. And S. F. Richard (1983): "Tests of a Rational Theory of the Size of Government," Public Choice, 41, 403-418.

Midgley, J. (1990): "The New Christian Right, Social Policy and the Welfare State," Journal of Sociology and Social Welfare, 17, 89-106.

Moene, K. O. And M. Wallerstein (2001): "Inequality, Social Insurance, and Redistribution," American Political Science Review, 95, 859-874.

- (2003): "Earnings Inequality and Welfare Spending: A Disaggregated Analysis," World Politics, 55, $485-516$.

Owens, M. L. (2007): God and Government in the Ghetto: The Politics of Church-State Collaboration in Black America, Chicago: University of Chicago Press.

PAstor, K. (2007): "3251 Broadway," Working paper, Urban Affairs.

Pollak, D. (2001): Have the U. S. Supreme Court's 5th Amendment Takings Decisions Changed Land Use Planning in California?, Diane Publishing Company.

Poole, K. T. And H. Rosenthal (1991): "Patterns of Congressional Voting," American Journal of Political Science, $35,228-278$.

- (1997): Congress: A Political-Economic History of Roll Call Voting, Oxford University Press.

Rasmussen, T. (2007): "Stat og religion," Norsk Teologisk Tidsskrift, 108, 1-6.

Roemer, J. E. (1998): "Why the Poor Do Not Expropriate the Rich: An Old Argument in New Garb," Journal of Public Economics, 70, 399 - 424.

Romer, T. (1975): "Individual Welfare, Majority Voting, and the Properties of a Linear Income Tax," Journal of 
Public Economics, 4, $163-185$.

Sandefur, T. (2005): "A Gleeful Obituary for Poletown Neighborhood Council v. Detroit," Harvard Journal of Law and Public Policy, 28, 651-678.

Scheve, K. And D. Stasavage (2006): "Religion and Preferences for Social Insurance," Quarterly Journal of Political Science, 1, 255-286.

Sen, M. (2011): "Is Justice Blind? Natural Experiments, Judicial Quality, and Racial Bias in Federal Appellate Review," Manuscript, Harvard University.

Sidenvall, E. (2012): "Church and state in Sweden: A Contemporary report," Kirchliche Zeitgeschichte, 25, 311-19. Smith, T. (2004): "Religious Affiliation and Philanthropy," Tech. rep., University of Illinois mimeo.

Steensland, B., J. Z. Park, M. D. Regnerus, L. D. Robinson, W. Wilcox, and R. D. Woodberry (2000): "The Measure of American Religion: Toward Improving the State of the Art," Social Forces, 79, 291-318.

Steinbuch, R. (2009): "An Empirical Analysis of Reversal Rates in the Eighth Circuit During 2008," Loyola of Los Angeles Law Review, 43, 51-19.

Sunstein, C. R., D. Schkade, L. M. Ellman, and A. Sawicki (2006): Are Judges Political?: An Empirical Analysis of the Federal Judiciary, Brookings Institution Press.

Thorkildsen, D. (2012): "The Role of the Church in contemporary Norway: Changed Relations between State and Church," Kirchliche Zeitgeschichte, 25, 272-92.

Townsend, R. M. (1994): "Risk and Insurance in Village India," Econometrica, 62, 539-591.

U.S. Department of Transportation, Federal Highway Administration (2005): "Acquiring Real Property for Federal and Federal-aid Programs and Projects," Publication No. FHWA-HEP-05-030.

van Bijsterveld, S. C. (2000): "Church and State in Western Europe and the United States: Principles and Perspectives," Brigham Young University Law Review.

Woodberry, R. D. And C. S. Smith (1998): "Fundamentalism et al: Conservative Protestants in America," Annual Review of Sociology, 24, 25-56.

Wuthnow, R. (1994): God And Mammon In America, Free Press.

(2004): "Mobilizing Civic Engagement: The Changing Impact of Religious Involvement," in Civic Engagement in American Democracy, ed. by T. Skocpol and M. Fiorina, Brookings Institution Press, 331-363. 


\section{APPENDIX A: DATA APPENDIX}

\section{A.1. General Social Survey}

The following variables are drawn from the U.S. General Social Survey's cross sectional cumulative data ${ }^{55}$ :

Prayer in Public School refers to the question, "The United States Supreme Court has ruled that no state or local government may require the reading of the Lord's Prayer or Bible verses in public schools. What are your views on this-do you approve or disapprove of the court ruling?" Disapprove is coded as 1, approve as 0. Variable name: prayer.

Abortion should be Illegal refers to the question, "Please tell me whether or not you think it should be possible for a pregnant woman to obtain a legal abortion if she wants it for any reason" No is coded as 1 , yes as 0 . Variable name: abany.

Women Belong at Home refers to the question, "Is it much better for everyone involved if the man is the achiever outside the home and the woman takes care of the home and family." Strongly agree and agree are coded as 1 , disagree and strongly disagree are coded as 0 . Variable name: fefam.

Premarital Sex is Wrong refers to the question, "There's been a lot of discussion about the way morals and attitudes about sex are changing in this country. If a man and woman have sex relations before marriage, do you think it is always wrong, almost always wrong, wrong only sometimes, or not wrong at all?" Always wrong is coded as 1 , the remainder as 0.4 . Variable name: premarsx.

Identify Republican refers to the question, "Generally speaking, do you usually think of yourself as a Republican, Democrat, Independent, or what?" Strong Republican is coded as 1, not very strong Republican, Independent close to Republican, Independent, Independent close to Democrat, Not very strong Democrat, Strong Democrat are coded as 0. 5. Variable name: partyid.

Pro-Equality refers to the question, "Some people think that the government in Washington ought to reduce the income differences between the rich and the poor, perhaps by raising the taxes of wealthy families or by giving income assistance to the poor. Others think that the government should not concern itself with reducing this income difference between the rich and the poor. Here is a card with a scale from 1 to 7 . Think of a score of 1 as meaning that the government ought to reduce the income differences between rich and poor, and a score of 7 meaning that the government should not concern itself with reducing income differences. What score between 1 and 7 comes closest to the way you feel?" 1 and 2 are coded as 1 and 3-7 coded as 0 . Variable name: eqwlth.

Politically Conservative refers to the question, "We hear a lot of talk these days about liberals and conservatives. I'm going to show you a seven-point scale on which the political views that people might hold are arranged from extremely liberal-point 1-to extremely conservative- point 7 . Where would you place yourself on this scale? Extremely conservative and conservative are coded as 1, slightly conservative, moderate, slightly liberal, liberal, and extremely liberal are coded as 0. Variable name: polviews.

Identify as Fundamentalist refers to the question, "Do you consider yourself to be fundamentalist, moderate, or liberal?" Fundamentalist is coded as 1, Moderate and Liberal as 0. Variable name: fund.

Congregation Helps You refers to the question, "If you were ill, how much would the people in your congregation help you out?" A great deal is coded as 1, some, a little, or none are coded as 0. Variable name: conghlp1.

Supports more welfare refers to the question "Are we spending too much, too little, or about the right amount for welfare?". Too little is coded 1 , too much and about right as 0 . Variable name: natfare.

Social Conservatism Index is a 0-1 index equal to the mean of the values on Prayer in Public Schools, Abortion Should be Illegal, Women Belong at Home, Premarital Sex is Wrong and Identify as a Fundamentalist

Religion Attendence refers to the question "How often do you attend religious services?" Variable name: attend.

FiscalConservatism and MoralConservatism are collections of responses to question that can be classified as measuring whether the respondent is fiscally conservative, i.e. favoring low taxes and low government expenditures, and morally conservative, i.e. favoring restrictions on abortion and related issues. The choice of variables is borrowed from (Ansolabehere et al., 2006). They include the following variables:

Fiscal conservative:

Confidence: Business (i) / Financial institutions refer to the question "I am going to name some institutions in this country. As far as the people running these institutions are concerned, would you say you have a great deal of confidence, only some confidence, or hardly any confidence at all in them?" "Hardly any" is coded 1, "Only some" is coded 2 and "a great deal" is coded 3. Variable names: conbus confinan.

Confidence: Organized labor refers to the same question as above for organized labor, but with the scale reversed: "A great deal" is coded 1 and "Hardly any" is coded 3. Variable name: conlabor.

Confidence: Business (ii) refers to the question "How much confidence do you have in business and industry" "No confidence at all" is coded 1, "Some confidence" is coded 3 and "Complete confidence" is coded 5. Variable name: conbiz.

\footnotetext{
${ }^{55}$ http://www3.norc.org/GSS+Website
} 
Equalize incomes (i) refers to the question "What is your opinion of the following statement? It is the responsibility of the government to reduce the differences in income between people with high incomes and those with low incomes." Coded from 1 ("Agree strongly") to 5 ("Disagree strongly"). Variable name: eqincome.

Equalize income (ii) refers to the question "On the whole, do you think it should or should not be the government's responsibility to reduce income differences between the rich and poor?" Coded from 1 ("Definetly should be") to 4 ("Definetly should not be"). Variable name: equalize.

Equalize income (iii) refers to "Do you agree or disagree? It is the responsibility of the government to reduce the differences in income between people with high incomes and those with low incomes." Coded from 1 ("Strongly agree") to 5 ("Strongly disagree"). Variable name: goveqinc.

Equalize wealth (i) and (ii) refer to the question "Some people think that the government in Washington ought to reduce the income differences between the rich and the poor, perhaps by raising the taxes of wealthy families or by giving income assistance to the poor. Others think that the government should not concern itself with reducing this income difference between the rich and the poor. Here is a card with a scale from 1 to 7 . Think of a score of 1 as meaning that the government ought to reduce the income differences between rich and poor, and a score of 7 meaning that the government should not concern itself with reducing income differences. What score between 1 and 7 comes closest to the way you feel?" Variable names: eqwlth eqwlthy.

Government help general refers to the question "Some people think that the government in Washington is trying to do too many things that should be left to individuals and private businesses. Others disagree and think that the government should do even more to solve our country's problems. Still others have opinions somewhere in between. Where would you place yourself on this scale, or haven't you made up your mind on this?" Coded from 1 ("government do more") to 5 ("government doing too much"). Variable name: helpnot.

Government help poor refers to the question "Some people think that the government in Washington should do everything possible to improve the standard of living of all poor Americans; they are at Point 1 on this card. Other people think it is not the government's responsibility, and that each person should take care of himself; they are at Point 5. Where would you place yourself on this scale, or haven't you have up your mind on this?" Coded from 1 ("government do more") to 5 ("government doing too much"). Variable name: helppoor.

Government help sick refers to the question "In general, some people think that it is the responsibility of the government in Washington to see to it that people have help in paying for doctors and hospital bills. Others think that these matters are not the responsibility of the federal government and that people should take care of these things themselves. Where would you place yourself on this scale, or haven't you made up your mind on this?" Coded from 1 ("government do more") to 5 ("government doing too much"). Variable name: helpsick.

Help cities, Pro environment, Pro welfare and Pro health refer to the question "We are faced with many problems in this country, none of which can be solved easily or inexpensively. I'm going to name some of these problems, and for each one I'd like you to name some of these problems, and for each one I'd like you to tell me whether you think we're spending too much money on it, too little money, or about the right amount." "Too Little" is coded 1, "About Right" is coded 2 and "Too Much" is coded 3. Variable names: natcity natcityy natcityz natenvir natenviy natenviz natfare natfarey natfarez natheal nathealy nathealz.

Cut taxes refers to the question "Do you consider the amount of federal income tax which you have to pay as too high, about right, or too low?" "Too low" is coded 1, "About right" is coded 2 and "too high" is coded 3 . Variable name: tax.

Moral conservative:

Abortion: ... (i) refer to the questions "Please tell me whether or not you think it should be possible for a pregnant woman to obtain a legal abortion if..." where circumstances are : "the women wants it for any reason", "there is a strong chance of serious defect in the baby", "the woman's own health is seriously endangered by the pregnancy?", "she is married and does not want any more children?", "the family has a very low income and cannot afford any more children?", "she became pregnant as a result of rape?" and "she is not married and doest not want to marry the man?". Yes is coded 1, No is coded 2. Variable names: abany abdefect abhlth abnomore abpoor abrape absingle.

Abortion: any reason (ii) refer to the question "Do you agree or disagree. A pregnant woman should be able to obtain a legal abortion for any reason whatsoever, if she chooses not to have the baby." Coded from 1 ("Strongly agree") to 5 ("strongly disagree"). Variable name: abchoose.

Abortion: Defect (ii) and Family Poor (ii) refer to the question "Do you think the law should or should not allow a pregnant woman to obtain a legal abortion ..." "If there is a strong chance of serious defect in the baby" and "If the family has a very low income and cannot afford any more children". Coded from 1 ("Definetly should allow it") to 4 ("Definetly should not allow it"). Variable names: abdefct1 abpoor1.

Teacher: Atheist, Book in library: Atheist, Free speech: Atheist refer to the questions "There are always some people whose ideas are considered bad or dangerous by other people. For instance, somebody who is against all churches and religion / Should such a person be allowed to teach in a college or university, or not? / If some people in your community suggested that a book he wrote against churches and religion should be taken out of your public library, would you favor removing this book, or not? / If such a person wanted to make a speech in your 
(city/town/community) against churches and religion, should he be allowed to speak, or not?" Yes is coded 1, No is coded 2. Variable names: colath spkath libath.

Teacher: Homosexual, Book in library: Homosexual, Free speech: Homosexual refer to the questions "And what about a man who admits that he is a homosexual? Should such a person be allowed to teach in a college or university, or not? / If some people in your community suggested that a book he wrote in favor of homosexuality should be taken out of your public library, would you favor removing this book, or not? / Suppose this admitted homosexual wanted to make a speech in your community. Should he be allowed to speak, or not?" Yes is coded 1 , No is coded 2. Variable names: colhomo libhomo spkhomo.

Confidence in organized religion (i) refers to the question "I am going to name some institutions in this country. As far as the people running these institutions are concerned, would you say you have a great deal of confidence, only some confidence, or hardly any confidence at all in them? C. Organized religion" "Hardly any" is coded 1, "only some" is coded 2 and "a great deal" is coded 3. Variable name: conclerg.

Confidence in organized religion (ii) refers to the question "I am going to name some institutions in this country. Some people have complete confidence in the people running these institutions. Suppose these people are at one end of the scale at point number 1 . Other people have no confidence at all in the people running these institutions. Suppose these people are at the other end, at point 7. And, of course, other people have opinions somewhere in between at point 2, 3, 4, 5 or 6 . Where would you place yourself on this scale for... C. Organized religion" "No confidence" is coded 1, "Complete confidence" is coded 7. Variable name: conclery.

Legalize marijuana (i) and (ii) refer to the question "Do you think the use of marijuana should be made legal or not?" "Make use legal" is coded 1, "don't make use legal" is coded 2. Variable names: grass grassy.

Homosexual relations (i) and (ii) refer to the question "What about sexual relations between two adults of the same sex-do you think it is always wrong, almost always wrong, wrong only sometimes, or not wrong at all?" "Not wrong at all" is coded 1, "always wrong" is coded 4. Variable name: homosex.

Pornography laws refer to the question "Which of these statements comes closest to your feelings about pornography laws? There should be laws against the distribution of pornography whatever the age. There should be laws against the distribution of pornography to persons under 18, There should be no laws forbidding the distribution of pornography" No laws is coded as 1, laws against distribution watever the age is coded as 3. Variable name: pornlaw.

Religiosity refers to the question "Would you call yourself a strong (PREFERENCE NAMED IN RELIG) or a not very strong (PREFERENCE NAMED IN RELIG)?" "No religion" is coded as 1, "strong" is coded as 4 . Variable name: reliten.

Extramarital relation refers to the question "What is your opinion about a married person having sexual relations with someone other than the marriage partner-is it always wrong, almost always wrong, wrong only sometimes, or not wrong at all?" "Not wrong at all" is coded 1, "always wrong" is coded 4. Variable name: xmarsex.

Religious denominations are classified following the RELTRAD scheme presented by Steensland et al. (2000).

\section{A.2. World Value Survey}

The following variables are taken from the World Values Survey (Waves 1-5).

Government responsibility: refers to the question "Now I'd like you to tell me your views on various issues. How would you place your views on this scale? 1 means you agree completely with the statement on the left, 10 means you agree completely with the statement on the right, or you can choose any number in between. 1: People should take more responsibility for providing for themselves, 10: The state should take more responsibility to ensure that everyone is provided for". Variable name: E037.

Income equality: refers to the above question for "1: Incomes should be made more equal, 10: There should be greater incentives for indivicual effort". Variable name: E035.

Attendance: refers to the question "Apart from weddings, funerals and christenings, about how often do you attend religious services these days?" "Only on special holy days/Christmas/Easter days" and "Other specific holy days" were merged together. The variable is coded from 0 (Never, practically never) to 7 (More than once a week). Variable name: F028.

Drespect refers to the question "Which of these two statements do you tend to agree with? A) Regardless of what the qualities and faults of ones parents are, one must always love and respect them, B) One does not have the duty to respect and love parents who have not earned it by their behaviour and attitudes" Answer A is coded 1. Variable name: A025.

Dbest refers to the question "Which of the following statements best describes your views about parents' responsibilities to their children? 1) Parents duty is to do their best for their children even at the expense of their own well-being, 2) Parents have a life of their own and should not be asked to sacrifice their own well-being for the sake of their children, 3) Neither". Answer 1 is coded 1. Variable name: A026. 
Dmanners, Dfaith, Dobey, Dindep, Dimagine, Dtolerate refer to the question "Here is a list of qualities which children can be encouraged to learn at home. Which, if any, do you consider to be especially important? Please choose up to five." Variable names: A027, A040, A042, A029, A034 and A035.

Dfaith2 refers to the questions "Here is a shorter list of things that children can be encouraged to learn. If you had to choose, which one of these do you consider to be the most important thing for a child to learn at home?" It is coded 1 if either "Obedience" or "Religious faith" is answered. Variable name: A044.

Dfemhome refers to the question "Do you agree or disagree with the following statement? When jobs are scarce, men should have more right to a job than women." Agree is coded 1. Variable name: C001.

Dfemchild refers to the question "Do you think that a woman has to have children in order to be fulfilled or is this not necessary?" "Needs children" is coded 1. Variable name: D019.

Dmarriage refers to the question "Do you agree or disagree with the following statement? Marriage is an out-dated institution" Yes is coded 1. Variable name: D022.

Dsexfree refers to the question "If someone said that individuals should have the chance to enjoy complete sexual freedom without being restricted, would you tend to agree or disagree?" "Tend to agree" is coded 1. Variable name: D024.

Dwedlock refers to "If a woman wants to have a child as a single parent but she doesn't want to have a stable relationship with a man, do you approve or disapprove?" Approve is coded 1. Variable name: D023.

Dabsolute refers to "Here are two statements which people sometimes make when discussing good and evil. Which one comes closest to your own point of view? A. There are absolutely clear guidelines about what is good and evil. These always apply to everyone, whatever the circumstances. B. There can never be absolutely clear guidelines about what is good and evil. What is good and evil depends entirely upon the circumstances at the time" Answer A is coded 1. Variable name: F022.

Dhomobad, Dprolife, Ddivorcebad and Deuthanbad refers to "Please tell me for each of the following statements whether you think it can always be justified, never be justified, or something in between" "Never be justified" is coded 1. Variable names: F118, F120, F121, F122.

\section{A.3. Church-State Separation Data}

The first church-state separation dataset is drawn from Barro and McCleary (2005), which is based on Barrett (1982) and Barrett et al. (2001). They classify countries as having a state religion if the constitution designates an official state church and restricts or prohibits other forms of religion, or, if the government merely systematically favors a specified religion through subsidies and tax collection or through the teaching of religion in public school. Countries with no state religion include Australia, Belgium, Canada, France, Mexico, and the United States. Countries with state religion include Iceland, Denmark, Norway, United Kingdom, Italy, Iran, Iraq, Libya, Nepal, and Greece, just to name a few. The entire list is in Table 1a-1g of Barro and McCleary (2005). The dataset is merged with the WVS by country.

The second church-state separation dataset comes from Finke and Grim (2006). ${ }^{56}$ Specifically we use three standarized indices (Government Regulation of Religion (GRI), Government Favoritism of Religion (GFI), and Social Regulation of Religion (SRI)) as well as a variable on favoritism (refering to the question "According to the Report, to what extent does the state provide a select religion or small group of religions with privileges, financial support, or favorable sanctions?"). The dataset is merged with the WVS by country.

\section{A.4. Donation Data}

Philanthropic data comes from the 2001-2009 extract of the Panel Study of Income Dynamics. ${ }^{57}$ The question on religious giving is, "Did you make any donations specifically for religious purposes or spiritual development, for example to a church, synagogue, mosque, TV or radio ministry? Please do not include donations to schools, hospitals, and other charities run by religious organizations."

Within-group giving variable is, for each religious group, the average proportion of giving going to religion. It is first computed using the SRC representative subsample in the COPPS philantropic data, and merged with the GSS data by religious preference.

\footnotetext{
${ }^{56}$ http://www.thearda.com/Archive/Files/Descriptions/IRFAGG.asp

${ }^{57}$ Available at http://www.philanthropy.iupui.edu/philanthropy-panel-study.
} 
APPENDIX TABLE I

OUTCOME VARIABLES IN THE US DATA

\begin{tabular}{|c|c|c|c|c|}
\hline Variable & GSS name & Range & Mean & Obs \\
\hline \multicolumn{5}{|l|}{ Fiscal variables } \\
\hline Confidence: Business (ii) & conbiz & $1-5$ & 2.99 & 3814 \\
\hline Confidence: Business (i) & conbus & $1-3$ & 2.09 & 37175 \\
\hline Confidence: Financial inst & confinan & $1-3$ & 2.08 & 35053 \\
\hline Confidence: Organized labor & conlabor & $1-3$ & 2.20 & 36504 \\
\hline Equalize incomes (i) & eqincome & $1-5$ & 3.14 & 1867 \\
\hline Equalize incomes (ii) & equalize & $1-4$ & 2.58 & 6764 \\
\hline Equalize wealth (i) & eqwlth & $1-7$ & 3.72 & 28600 \\
\hline Equalize wealth (ii) & eqwlthy & $1-7$ & 3.67 & 749 \\
\hline Equalize incomes (iii) & goveqinc & $1-5$ & 3.21 & 10242 \\
\hline Gov. help general & helpnot & $1-5$ & 3.04 & 26920 \\
\hline Gov. help poor & helppoor & $1-5$ & 2.89 & 27570 \\
\hline Gov. help sick & helpsick & $1-5$ & 2.46 & 27646 \\
\hline Help cities (i) & natcity & $1-3$ & 1.65 & 29096 \\
\hline Help cities (ii) & natcityy & $1-3$ & 2.12 & 17090 \\
\hline Help cities (iii) & natcityz & $1-3$ & 1.63 & 427 \\
\hline Pro environment (i) & natenvir & $1-3$ & 1.48 & 31614 \\
\hline Pro environment (ii) & natenviy & $1-3$ & 1.43 & 19105 \\
\hline Pro environment (iii) & natenviz & $1-3$ & 1.49 & 465 \\
\hline Pro welfare (i) & natfare & $1-3$ & 2.28 & 31758 \\
\hline Pro welfare (ii) & natfarey & $1-3$ & 1.45 & 19447 \\
\hline Pro welfare (iii) & natfarez & $1-3$ & 1.38 & 473 \\
\hline Pro health (i) & natheal & $1-3$ & 1.40 & 32081 \\
\hline Pro health (ii) & nathealy & $1-3$ & 1.41 & 19441 \\
\hline Pro health (iii) & nathealz & $1-3$ & 1.46 & 465 \\
\hline Cut taxes & $\operatorname{tax}$ & $1-3$ & 2.62 & 30008 \\
\hline \multicolumn{5}{|l|}{ Moral variables } \\
\hline Abortion: Any reason (i) & abany & $1-2$ & 1.59 & 31807 \\
\hline Abortion: Any reason (ii) & abchoose & $1-5$ & 3.04 & 1332 \\
\hline Abortion: Defect( ii) & abdefct1 & $1-4$ & 1.65 & 1262 \\
\hline Abortion: Defect (i) & abdefect & $1-2$ & 1.20 & 39216 \\
\hline Abortion: Mother's health & abhlth & $1-2$ & 1.10 & 39384 \\
\hline Abortion: Preference & abnomore & $1-2$ & 1.56 & 39093 \\
\hline Abortion: Family poor (i) & abpoor & $1-2$ & 1.53 & 39028 \\
\hline Abortion: Family poor (ii) & abpoor 1 & $1-4$ & 2.36 & 1219 \\
\hline Abortion: Rape & abrape & $1-2$ & 1.18 & 38981 \\
\hline Abortion: Mother single & absingle & $1-2$ & 1.56 & 39020 \\
\hline Teacher: Atheist & colath & $1-2$ & 1.48 & 34823 \\
\hline Teacher: Homosexual & colhomo & $1-2$ & 1.32 & 33283 \\
\hline Conf. in org. religion (i) & conclerg & $1-3$ & 2.08 & 37362 \\
\hline Conf. in org. religion (ii) & conclery & $1-7$ & 4.54 & 464 \\
\hline Legalize marijuana (i) & grass & $1-2$ & 1.73 & 32682 \\
\hline Legalize marijuana (ii) & grassy & $1-2$ & 1.67 & 743 \\
\hline Homosexual relations (i) & homosex & $1-4$ & 3.15 & 32707 \\
\hline Homosexual relations (ii) & homosex1 & $1-4$ & 3.14 & 4903 \\
\hline Book in library: Atheist & libath & $1-2$ & 1.32 & 35156 \\
\hline Book in library: Homosexual & libhomo & $1-2$ & 1.33 & 33487 \\
\hline Pornography laws & pornlaw & $1-3$ & 2.34 & 33953 \\
\hline Religiosity & reliten & $1-4$ & 3.05 & 52101 \\
\hline Free speech: Atheist & spkath & $1-2$ & 1.29 & 35732 \\
\hline Free speech: Homosexual & spkhomo & $1-2$ & 1.24 & 33516 \\
\hline Extramarital relation (i) & xmarsex & $1-4$ & 3.63 & 34019 \\
\hline Extramarital relation (ii) & xmarsex 1 & $1-4$ & 3.69 & 5235 \\
\hline
\end{tabular}


APPENDIX TABLE II

OTHER VARIABLES IN THE US DATA

\begin{tabular}{lccccc}
\hline & Mean & Std dev & Min & Max & Obs \\
\hline Religious attendance & 3.83 & 2.71 & 0.00 & 8.00 & 56512 \\
Social conservatism & 0.36 & 0.38 & 0.00 & 1.00 & 56171 \\
Within-group giving & 0.61 & 0.16 & 0.40 & 0.91 & 43996 \\
Log income & 9.95 & 1.01 & 5.50 & 12.00 & 51231 \\
Age & 45.70 & 17.47 & 18.00 & 89.00 & 56859 \\
Highest year of school completed & 12.75 & 3.18 & 0.00 & 20.00 & 56897 \\
Gender & 1.56 & 0.50 & 1.00 & 2.00 & 57061 \\
Fundamentalist & 0.31 & 0.46 & 0.00 & 1.00 & 54907 \\
Religion: Evangelical protestant & 0.31 & 0.46 & 0.00 & 1.00 & 43996 \\
Religion: Mormon & 0.14 & 0.35 & 0.00 & 1.00 & 43996 \\
Religion: Catholic & 0.32 & 0.47 & 0.00 & 1.00 & 43996 \\
Religion: Jewish & 0.03 & 0.16 & 0.00 & 1.00 & 43996 \\
Religion: Other & 0.05 & 0.22 & 0.00 & 1.00 & 43996 \\
Religion: No religion & 0.14 & 0.35 & 0.00 & 1.00 & 43996 \\
Race: White & 0.81 & 0.39 & 0.00 & 1.00 & 57061 \\
Race: Black & 0.14 & 0.35 & 0.00 & 1.00 & 57061 \\
Race: Other & 0.05 & 0.22 & 0.00 & 1.00 & 57061 \\
Marital status: Married & 0.54 & 0.50 & 0.00 & 1.00 & 57041 \\
Marital status: Widowed & 0.10 & 0.30 & 0.00 & 1.00 & 57041 \\
Marital status: Divorced & 0.12 & 0.33 & 0.00 & 1.00 & 57041 \\
Marital status: Separated & 0.03 & 0.18 & 0.00 & 1.00 & 57041 \\
Marital status: Never married & 0.20 & 0.40 & 0.00 & 1.00 & 57041 \\
\hline
\end{tabular}


APPENDIX TABLE III

VARIABLES IN THE WORLDWIDE DATA

\begin{tabular}{lccccc}
\hline & Mean & Std dev & Min & Max & Obs \\
\hline Government responsibility & 6.22 & 3.02 & 1.00 & 10.00 & 234148 \\
Income equality & 5.93 & 3.02 & 1.00 & 10.00 & 230171 \\
Attendance & 3.62 & 2.58 & 0.00 & 7.00 & 238981 \\
Lives in country with SC & 0.39 & 0.49 & 0.00 & 1.00 & 257612 \\
Belongs to SC & 0.26 & 0.44 & 0.00 & 1.00 & 257612 \\
Income level & 4.51 & 2.39 & 1.00 & 10.00 & 226003 \\
Age & 40.31 & 15.91 & 14.00 & 99.00 & 247978 \\
Female & 0.52 & 0.50 & 0.00 & 1.00 & 252941 \\
Education: Less than elementary & 0.14 & 0.35 & 0.00 & 1.00 & 230283 \\
Education: Elementary & 0.15 & 0.35 & 0.00 & 1.00 & 230283 \\
Education: Incomplete secondary & 0.07 & 0.26 & 0.00 & 1.00 & 230283 \\
Education: Intermediate vocational secondary & 0.17 & 0.38 & 0.00 & 1.00 & 230283 \\
Education: Intermediate general secondary & 0.09 & 0.28 & 0.00 & 1.00 & 230283 \\
Education: Full secondary & 0.16 & 0.37 & 0.00 & 1.00 & 230283 \\
Education: Some university w/o degree & 0.07 & 0.26 & 0.00 & 1.00 & 230283 \\
Education: University with degree & 0.14 & 0.35 & 0.00 & 1.00 & 230283 \\
Marital status: Married & 0.58 & 0.49 & 0.00 & 1.00 & 253001 \\
Marital status: Cohabitation & 0.06 & 0.24 & 0.00 & 1.00 & 253001 \\
Marital status: Divorced & 0.03 & 0.17 & 0.00 & 1.00 & 253001 \\
Marital status: Separated & 0.02 & 0.13 & 0.00 & 1.00 & 253001 \\
Marital status: Widowed & 0.06 & 0.24 & 0.00 & 1.00 & 253001 \\
Marital status: Never married & 0.25 & 0.43 & 0.00 & 1.00 & 253001 \\
Marital status: Divorced, Separated or Widow & 0.00 & 0.02 & 0.00 & 1.00 & 253001 \\
Marital status: Living apart but steady relation & 0.00 & 0.01 & 0.00 & 1.00 & 253001 \\
\hline
\end{tabular}

APPENDIX TABLE IV

The Finke/GRIM DATA

\begin{tabular}{|c|c|c|c|c|}
\hline Variable & Overall mean & With state church & Without state church & Difference \\
\hline \multirow[t]{2}{*}{ Government Regulation index (GRI) } & 3.58 & 4.75 & 2.76 & 1.99 \\
\hline & $(2.91)$ & $(3.01)$ & $(2.55)$ & {$[0.00]$} \\
\hline \multirow[t]{2}{*}{ Social Regulation Index (SRI) } & 4.32 & 5.33 & 3.61 & 1.72 \\
\hline & $(2.90)$ & $(3.07)$ & $(2.56)$ & {$[0.01]$} \\
\hline \multirow[t]{2}{*}{ Government Favoritism Index (GFI) } & 5.61 & 6.96 & 4.66 & 2.30 \\
\hline & $(2.45)$ & $(1.87)$ & $(2.38)$ & {$[0.00]$} \\
\hline \multirow[t]{2}{*}{ Government favoritism for specific group } & 3.26 & 4.46 & 2.41 & 2.05 \\
\hline & $(1.83)$ & $(1.47)$ & $(1.56)$ & {$[0.00]$} \\
\hline
\end{tabular}

Notes: The table shows country averages of the variables from Finke and Grim (2006) used in the paper, broken down by Barro and McCleary's (2005) state church classification. Standard deviations in parentheses, and p-values from a t-test using Satterthwaite's degrees of freedom correction in square brackets. 
APPENDIX TABLE V

Variables in the Swedish and Norwegian Sample

\begin{tabular}{lccccc}
\hline & Mean & Std dev & Min & Max & Obs \\
\hline Taxes on high incomes should be reduced & 2.62 & 1.42 & 1.00 & 5.00 & 20607 \\
It is not important to reduce income differences & 3.56 & 1.28 & 1.00 & 5.00 & 20456 \\
Preserving Christian values is important & 2.78 & 1.31 & 1.00 & 5.00 & 16207 \\
Period & 3.03 & 1.44 & 1.00 & 5.00 & 28095 \\
Sweden & 0.63 & 0.48 & 0.00 & 1.00 & 28095 \\
\hline
\end{tabular}

APPENDIX TABLE VI

Fiscal and Social Conservatism/Liberalism in the U.S. - Interactions

\begin{tabular}{lcc}
\hline & $\begin{array}{c}\text { Fiscal conservative } \\
(1)\end{array}$ & $\begin{array}{c}\text { Moral conservative } \\
(2)\end{array}$ \\
\hline Religious attendance & $0.0114^{* * *}$ & $0.0871^{* * *}$ \\
Fundamentalist & $(0.00249)$ & $(0.00199)$ \\
& 0.0133 & $0.217^{* * *}$ \\
Attendance $\times$ Fundamentalist & $(0.0131)$ & $(0.0104)$ \\
& 0.00435 & -0.00384 \\
Observations & $(0.00396)$ & $(0.00322)$ \\
\hline
\end{tabular}

Notes:

1. Data are from General Social Survey cumulative file, 1972-2012. All estimates are average effect size estimates. Standard errors in parentheses are adjusted for correlation within region of residence.

2. All specifications include dummies for region of residence, marital status, year, race, and gender, and controls for the log of income, age, age-squared, and years of completed schooling.

3. Missing values in control variables are replaced by the value 0 and a dummy for the variable being missing is included.

4. Social Conservatism is a 0-1 index summing up values on Prayer in Public School, Women Belong at Home, Premarital Sex is Wrong, and Identify as Fundamentalist. 
APPENDIX TABLE VII

Fiscal and Social Conservatism/Liberalism in the U.S. - Alternative variable definition

\begin{tabular}{lccccccc}
\hline & \multicolumn{3}{c}{ Fiscal conservative } & & \multicolumn{3}{c}{ Moral conservative } \\
\cline { 2 - 3 } & $(1)$ & $(2)$ & $(3)$ & & $(4)$ & $(5)$ & $(6)$ \\
\hline Religious attendance & $0.0140^{* * *}$ & & $0.0118^{* * *}$ & & $0.0904^{* * *}$ & & $0.0796^{* * * *}$ \\
& $(0.00195)$ & & $(0.00176)$ & & $(0.00351)$ & & $(0.00263)$ \\
Social conservativism & & $0.0868^{* * *}$ & $0.0647^{* * *}$ & & $0.483^{* * *}$ & $0.357^{* * *}$ \\
& & $(0.0111)$ & $(0.00995)$ & & & $0.0307)$ & $(0.0160)$ \\
\hline Observations & 54541 & 54166 & 53728 & & 56170 & 55821 & 55373 \\
\hline Notes: & & & & & & &
\end{tabular}

1. Data are from General Social Survey cumulative file, 1972-2012. All estimates are average effect size estimates. Standard errors in parentheses are adjusted for correlation within region of residence.

2. All specifications include dummies for region of residence, marital status, year, race, and gender, and controls for the log of income, age, age-squared, and years of completed schooling.

3. Missing values in control variables are replaced by the value 0 and a dummy for the variable being missing is included.

4. Social Conservatism is a 0-1 index summing up values on Prayer in Public School, Women Belong at Home, Premarital Sex is Wrong, and Identify as Fundamentalist. 


\section{APPENDIX TABLE VIII}

Fiscal and Social Conservatism/Liberalism in the U.S. - By Racial group

A. White

\begin{tabular}{lccccccc}
\hline & \multicolumn{3}{c}{ Fiscal conservative } & & \multicolumn{3}{c}{ Moral conservative } \\
\cline { 2 - 3 } \cline { 7 - 8 } & $(1)$ & $(2)$ & $(3)$ & & $(4)$ & $(5)$ & $(6)$ \\
\hline Religious attendance & $0.0189^{* * *}$ & & $0.0174^{* * *}$ & & $0.0978^{* * *}$ & & $0.0919^{* * *}$ \\
& $(0.00180)$ & & $(0.00189)$ & & $(0.00306)$ & & $(0.00247)$ \\
Fundamentalist & & $0.0647^{* * *}$ & $0.0464^{* * *}$ & & $0.327^{* * *}$ & $0.238^{* * *}$ \\
& & $(0.0163)$ & $(0.0138)$ & & & $(0.0263)$ & $(0.0118)$ \\
\hline Observations & 44330 & 43311 & 43003 & & 45690 & 44661 & 44345 \\
\hline
\end{tabular}

B. Black

\begin{tabular}{lccccccc}
\hline & \multicolumn{3}{c}{ Fiscal conservative } & & \multicolumn{3}{c}{ Moral conservative } \\
\cline { 2 - 3 } \cline { 7 - 8 } & $(1)$ & $(2)$ & $(3)$ & & $(4)$ & $(5)$ & $(6)$ \\
\hline Religious attendance & -0.0000616 & & 0.000932 & & $0.0597^{* * *}$ & & $0.0586^{* * *}$ \\
& $(0.00393)$ & & $(0.00385)$ & & $(0.00469)$ & & $(0.00512)$ \\
Fundamentalist & & -0.0184 & -0.0182 & & $0.118^{* * *}$ & $0.0809^{* * *}$ \\
& & $(0.0127)$ & $(0.0159)$ & & & $(0.0144)$ & $(0.0184)$ \\
\hline Observations & 7482 & 7265 & 7200 & & 7746 & 7527 & 7460 \\
\hline
\end{tabular}

Notes:

1. Data are from General Social Survey cumulative file, 1972-2012. All estimates are average effect size estimates. Standard errors in parentheses are adjusted for correlation within region of residence.

2. All specifications include dummies for region of residence, marital status, year, race, and gender, and controls for the log of income, age, age-squared, and years of completed schooling. 3. Missing values in control variables are replaced by the value 0 and a dummy for the variable being missing is included.

4. Social Conservatism is a 0-1 index summing up values on Prayer in Public School, Women Belong at Home, Premarital Sex is Wrong, and Identify as Fundamentalist. 
APPENDIX TABLE IX

Fiscal and Social Conservatism/Liberalism in the U.S. - Detailed estimates

\begin{tabular}{|c|c|c|c|c|c|c|c|c|c|}
\hline \multirow{3}{*}{ Fiscal conservative } & \multicolumn{2}{|c|}{ (1) } & \multicolumn{2}{|c|}{$(2)$} & \multicolumn{4}{|c|}{ (3) } & \multirow[t]{2}{*}{ Obs. } \\
\hline & \multicolumn{2}{|c|}{ Relig. attendance } & \multicolumn{2}{|c|}{ Socially conservative } & \multicolumn{2}{|c|}{ Relig. attendance } & \multicolumn{2}{|c|}{ Socially conservative } & \\
\hline & & & & & & & & & \\
\hline Confidence: Business (i) & $0.0120^{* * *}$ & $(0.0011)$ & -0.0169 & $(0.0122)$ & $0.0136^{* * *}$ & $(0.0011)$ & $-0.0403^{* *}$ & $(0.0129)$ & 36086 \\
\hline Confidence: Financial inst & $0.0146^{* * *}$ & $(0.0014)$ & 0.0151 & $(0.0083)$ & $0.0151^{* * *}$ & $(0.0014)$ & -0.0084 & $(0.0093)$ & 33974 \\
\hline Confidence: Organized labor & -0.0002 & $(0.0014)$ & $0.0437^{* * *}$ & $(0.0076)$ & -0.0017 & $(0.0013)$ & $0.0467 * * *$ & $(0.0082)$ & 35452 \\
\hline Equalize incomes (i) & $0.0291^{* * *}$ & $(0.0062)$ & 0.0500 & $(0.0860)$ & $0.0295^{* * *}$ & $(0.0053)$ & 0.0077 & $(0.0791)$ & 1821 \\
\hline Equalize wealth (ii) & 0.0469 & $(0.0340)$ & $0.3331^{*}$ & $(0.1784)$ & 0.0389 & $(0.0371)$ & 0.2579 & $(0.2111)$ & 737 \\
\hline Equalize incomes (iii) & $0.0184^{* * *}$ & $(0.0034)$ & $0.1051^{*}$ & $(0.0483)$ & $0.0156^{* * *}$ & $(0.0028)$ & 0.0734 & $(0.0485)$ & 9877 \\
\hline Gov. help general & $0.0207^{* * *}$ & $(0.0033)$ & $0.1103^{* * *}$ & $(0.0322)$ & $0.0186^{* * *}$ & $(0.0036)$ & $0.0758^{*}$ & $(0.0334)$ & 26026 \\
\hline Gov. help poor & $0.0145^{* * *}$ & $(0.0031)$ & $0.1277^{* * *}$ & $(0.0352)$ & $0.0114^{* *}$ & $(0.0037)$ & $0.1090^{* *}$ & $(0.0375)$ & 26646 \\
\hline Gov. help sick & $0.0296^{* * *}$ & $(0.0031)$ & $0.2092^{* * *}$ & $(0.0324)$ & $0.0246^{* * *}$ & $(0.0037)$ & $0.1701 * * *$ & $(0.0344)$ & 26728 \\
\hline Help cities (i) & $0.0055^{* *}$ & $(0.0021)$ & $0.0739 * *$ & $(0.0246)$ & $0.0032^{*}$ & $(0.0015)$ & $0.0671^{* *}$ & $(0.0213)$ & 28352 \\
\hline Pro welfare (i) & $0.0140 * * *$ & $(0.0015)$ & $0.0941^{* * *}$ & $(0.0165)$ & $0.0117^{* * *}$ & $(0.0017)$ & $0.0749^{* * *}$ & $(0.0164)$ & 30944 \\
\hline Pro welfare (ii) & $0.0065 *$ & $(0.0030)$ & $0.0598^{* *}$ & $(0.0228)$ & 0.0049 & $(0.0030)$ & $0.0496^{* *}$ & $(0.0214)$ & 18815 \\
\hline Pro welfare (iii) & -0.0028 & $(0.0080)$ & 0.0701 & $(0.0611)$ & -0.0052 & $(0.0091)$ & 0.0782 & $(0.0652)$ & 457 \\
\hline Pro health (i) & $0.0112^{* * *}$ & $(0.0018)$ & $0.0545^{* * *}$ & $(0.0119)$ & $0.0099^{* * *}$ & $(0.0017)$ & $0.0387 * * *$ & $(0.0103)$ & 31259 \\
\hline Pro health (ii) & $0.0111^{* * *}$ & $(0.0023)$ & $0.0614^{* *}$ & $(0.0211)$ & $0.0096^{* * *}$ & $(0.0022)$ & $0.0450^{*}$ & $(0.0196)$ & 18813 \\
\hline Pro health (iii) & 0.0123 & $(0.0082)$ & 0.0102 & $(0.0724)$ & 0.0075 & $(0.0091)$ & 0.0082 & $(0.0747)$ & 448 \\
\hline Cut taxes & $-0.0038^{* * *}$ & $(0.0009)$ & $0.0421^{* * *}$ & $(0.0072)$ & $-0.0055^{* * *}$ & $(0.0008)$ & $0.0495^{* * *}$ & $(0.0070)$ & 29037 \\
\hline \multicolumn{10}{|l|}{ Moral conservative } \\
\hline Abortion: Any reasc & $0.0501^{* * *}$ & $(0.0027)$ & $0.2363^{* * *}$ & $(0.0$ & 0.04 & $(0.0$ & 0.161 & $(0$. & 30826 \\
\hline Abortion: Any reason (ii) & $0.1987^{* * *}$ & $(0.0127)$ & $1.0409^{* * *}$ & $(0.0773)$ & $0.1759^{* * *}$ & $(0.0123)$ & $0.7661^{* * *}$ & $(0.0460)$ & 1282 \\
\hline Abortion: Defect( ii) & $0.1263^{* * *}$ & $(0.0106)$ & $0.6813^{* * *}$ & $(0.1427)$ & $0.1106^{* * *}$ & $(0.0086)$ & $0.5385^{* * *}$ & $(0.1208)$ & 1227 \\
\hline Abortion: Defect (i) & $0.0398^{* * *}$ & $(0.0017)$ & $0.1701^{* * *}$ & $(0.0125)$ & $0.0365^{* * *}$ & $(0.0015)$ & $0.1110^{* * *}$ & $(0.0082)$ & 38096 \\
\hline Conf. in org. religion (ii) & $0.1011^{* * *}$ & $(0.0282)$ & 0.2214 & $(0.1487)$ & $0.1049 * * *$ & $(0.0275)$ & 0.1206 & $(0.1366)$ & 449 \\
\hline Legalize marijuana (i) & $0.0340^{* * *}$ & $(0.0014)$ & $0.1370^{* * *}$ & $(0.0141)$ & $0.0310^{* * *}$ & $(0.0010)$ & $0.0892^{* * *}$ & $(0.0103)$ & 31620 \\
\hline Legalize marijuana (ii) & $0.0400^{* * *}$ & $(0.0076)$ & $0.3889^{* * *}$ & $(0.0599)$ & $0.0293^{* * *}$ & $(0.0065)$ & $0.3265^{* * *}$ & $(0.0523)$ & 732 \\
\hline Homosexual relations (i) & $0.1138^{* * *}$ & $(0.0063)$ & $0.7147^{* * *}$ & $(0.0537)$ & $0.0961^{* * *}$ & $(0.0044)$ & $0.5659 * * *$ & $(0.0381)$ & 31681 \\
\hline Homosexual relations (ii) & $0.1123^{* * *}$ & $(0.0118)$ & $0.8991^{* * *}$ & $(0.0932)$ & $0.0882^{* * *}$ & $(0.0110)$ & $0.7564^{* * *}$ & $(0.0757)$ & 4726 \\
\hline Book in library: Atheist & $0.0250^{* * *}$ & $(0.0011)$ & $0.1868^{* * *}$ & $(0.0100)$ & $0.0203^{* * *}$ & $(0.0008)$ & $0.1549^{* * *}$ & $(0.0104)$ & 34053 \\
\hline Book in library: Homosexual & $0.0246^{* * *}$ & $(0.0010)$ & $0.2009 * * *$ & $(0.0132)$ & $0.0194 * * *$ & $(0.0006)$ & $0.1702^{* * *}$ & $(0.0127)$ & 32412 \\
\hline Pornography laws & $0.0454^{* * *}$ & $(0.0014)$ & $0.2267 * * *$ & $(0.0182)$ & $0.0404^{* * *}$ & $(0.0007)$ & $0.1648^{* * *}$ & $(0.0144)$ & 32855 \\
\hline Religiosity & $0.1769 * * *$ & $(0.0059)$ & $0.6578^{* * *}$ & $(0.0477)$ & $0.1669^{* * *}$ & $(0.0054)$ & $0.3550^{* * *}$ & $(0.0189)$ & 50894 \\
\hline Free speech: Atheist & $0.0166^{* * *}$ & $(0.0010)$ & $0.1298^{* * *}$ & $(0.0144)$ & $0.0133^{* * *}$ & $(0.0008)$ & $0.1087^{* * *}$ & $(0.0148)$ & 34594 \\
\hline Free speech: Homosexual & $0.0194 * * *$ & $(0.0016)$ & $0.1700^{* * *}$ & $(0.0130)$ & $0.0148^{* * *}$ & $(0.0010)$ & $0.1480^{* * *}$ & $(0.0119)$ & 32439 \\
\hline Extramarital relation (i) & $0.0531^{* * *}$ & $(0.0018)$ & $0.2418^{* * *}$ & $(0.0188)$ & $0.0480^{* * *}$ & $(0.0020)$ & $0.1669 * * *$ & $(0.0162)$ & 32926 \\
\hline Extramarital relation (ii) & $0.0457^{* * *}$ & $(0.0015)$ & $0.2603^{* * *}$ & $(0.0387)$ & $0.0403^{* * *}$ & $(0.0020)$ & $0.1898^{* * *}$ & $(0.0377)$ & 5050 \\
\hline
\end{tabular}

\section{Notes:}

1. The table shows all the estimated coefficients on religious attendance and socially conservative for outcomes on fiscal and moral conservativeness underlying Figure ?? Specification (1) includes attendance and controls, specification (2) socially conservative and controls, and specification (3) attendance, socially conservative, and controls.

2. Estimated coefficients are from OLS regressions controlling for the same variables as Table I. Missing values in control variables are replaced by the value 0 and a dummy for the variable being missing is included.

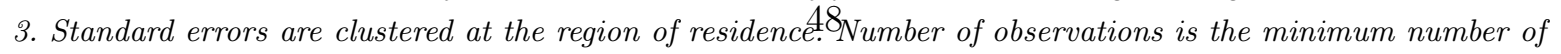
observations, taken from specification (3). 
APPENDIX TABLE X

Within-Group Giving and Fiscal/Social Conservatism in the US - Detailed estimates

\begin{tabular}{|c|c|c|c|}
\hline & \multicolumn{2}{|c|}{ Within-group giving } & Obs \\
\hline \multicolumn{4}{|l|}{ Fiscal conservative } \\
\hline Confidence: Business (ii) & $0.3524^{* * *}$ & $(0.0708)$ & 3004 \\
\hline Confidence: Business (i) & $0.1579 * *$ & $(0.0482)$ & 28251 \\
\hline Confidence: Financial inst & $0.2022^{* * *}$ & $(0.0310)$ & 26771 \\
\hline Confidence: Organized labor & $0.0961 * * *$ & $(0.0222)$ & 27713 \\
\hline Equalize incomes (i) & $0.4886^{* *}$ & $(0.1767)$ & 1425 \\
\hline Equalize incomes (ii) & $0.2955^{* *}$ & $(0.1220)$ & 5307 \\
\hline Equalize wealth (i) & $0.7074^{* * *}$ & $(0.1486)$ & 22254 \\
\hline Equalize wealth (ii) & $2.0101^{* *}$ & $(0.6007)$ & 545 \\
\hline Equalize incomes (iii) & $0.4586^{* *}$ & $(0.1539)$ & 8124 \\
\hline Gov. help general & $0.4843^{* * *}$ & $(0.0689)$ & 20920 \\
\hline Gov. help poor & $0.4622^{* * *}$ & $(0.0814)$ & 21469 \\
\hline Gov. help sick & $0.6974^{* * *}$ & $(0.0561)$ & 21510 \\
\hline Help cities (i) & $0.2315^{* * *}$ & $(0.0354)$ & 22051 \\
\hline Help cities (ii) & $0.4225^{* * *}$ & $(0.0647)$ & 13462 \\
\hline Help cities (iii) & 0.0646 & $(0.1823)$ & 318 \\
\hline Pro environment (i) & $0.3393^{* * *}$ & $(0.0511)$ & 23876 \\
\hline Pro environment (ii) & $0.3577^{* * *}$ & $(0.0689)$ & 15027 \\
\hline Pro environment (iii) & $0.7141^{* *}$ & $(0.2356)$ & 344 \\
\hline Pro welfare (i) & $0.3183^{* * *}$ & $(0.0281)$ & 23969 \\
\hline Pro welfare (ii) & $0.2061 * * *$ & $(0.0602)$ & 15336 \\
\hline Pro welfare (iii) & $0.5037^{*}$ & $(0.2210)$ & 352 \\
\hline Pro health (i) & $0.2059^{* * *}$ & $(0.0311)$ & 24284 \\
\hline Pro health (ii) & $0.1743^{* *}$ & $(0.0581)$ & 15311 \\
\hline Pro health (iii) & 0.1969 & $(0.3097)$ & 345 \\
\hline Cut taxes & $0.0877^{* *}$ & $(0.0345)$ & 23148 \\
\hline \multicolumn{4}{|l|}{ Moral conservative } \\
\hline Abortion: Any reason (i) & $0.5501 * * *$ & $(0.0556)$ & 24546 \\
\hline Abortion: Any reason (ii) & $1.7613^{* * *}$ & $(0.2383)$ & 1046 \\
\hline Abortion: Defect( ii) & $0.7076^{* *}$ & $(0.2688)$ & 992 \\
\hline Abortion: Defect (i) & $0.2446^{* * *}$ & $(0.0439)$ & 29695 \\
\hline Abortion: Mother's health & $0.0553^{* *}$ & $(0.0228)$ & 29803 \\
\hline Abortion: Preference & $0.5421 * * *$ & $(0.0617)$ & 29710 \\
\hline Abortion: Family poor (i) & $0.5304^{* * *}$ & $(0.0612)$ & 29643 \\
\hline Abortion: Family poor (ii) & $1.3374^{* *}$ & $(0.4190)$ & 953 \\
\hline Abortion: Rape & $0.2186^{* * *}$ & $(0.0433)$ & 29489 \\
\hline Abortion: Mother & $0.5295^{* * *}$ & $(0.0595)$ & 29661 \\
\hline Teacher: Atheist & $0.4020^{* * *}$ & $(0.0353)$ & 26584 \\
\hline Teacher: Homosexual & $0.4603^{* * *}$ & $(0.0350)$ & 25538 \\
\hline Conf. in org. religion (i) & $0.6764^{* * *}$ & $(0.0782)$ & 28402 \\
\hline Conf. in org. religion (ii) & 0.2125 & $(0.6244)$ & 346 \\
\hline Legalize marijuana (i) & $0.4460^{* * *}$ & $(0.0395)$ & 25058 \\
\hline Legalize marijuana (ii) & $0.8091 * * *$ & $(0.1238)$ & 542 \\
\hline Homosexual relations (i) & $2.0739^{* * *}$ & $(0.1339)$ & 25144 \\
\hline Homosexual relations (ii) & $2.1003^{* * *}$ & $(0.1370)$ & 3873 \\
\hline Book in library: Atheist & $0.4353^{* * *}$ & $(0.0510)$ & 26821 \\
\hline Book in library: Homosexual & $0.4681^{* * *}$ & $(0.0402)$ & 25651 \\
\hline Pornography laws & $0.6030^{* * *}$ & $(0.0340)$ & 26022 \\
\hline Religiosity & $2.9723^{* * *}$ & $(0.1512)$ & 40473 \\
\hline Free speech: Atheist & $0.2958^{* * *}$ & $(0.0438)$ & 27271 \\
\hline Free speech: Homosexual & $0.3632^{* * *}$ & $(0.0400)$ & 25690 \\
\hline Extramarital relation (i) & $0.7588^{* * *}$ & $(0.0720)$ & 26059 \\
\hline Extramarital relation (ii) & $0.6757^{* * *}$ & $(0.0730)$ & 4112 \\
\hline
\end{tabular}

Notes:

1. The table shows all the estimated coefficients on the fraction of the respondent's charitable giving going to the religious group for outcomes on fiscal and moral conservativeness underlying Table II.

2. Estimated coefficients are from OLS regressions controlling for the same variables as Table II. Missing values in control variables are replaced by the value 0 and a dummy for the variable being missing is included.

3. Standard errors are clustered at the region of residence. 
APPENDIX TABLE XI

Social Insurance and Religion

Congregation helps you a great deal if ill

(1) $0.0838^{* * *}$

\begin{tabular}{lr}
\hline Religious attendance & $0.0838^{* * *}$ \\
$(0.00961)$
\end{tabular}

Evangelical protestant (d)

Mainline protestant (d)

Catholic (d)

Other religion $(\mathrm{d})$

Jewish (d)

No religion
(2)

(3)

$\begin{array}{lc}0.378^{* *} & 0.570^{* * *} \\ (0.157) & (0.0419) \\ 0.280^{*} & 0.462^{* * *} \\ (0.163) & (0.0594) \\ 0.0998 & 0.273^{* * *} \\ (0.138) & (0.0383) \\ 0.482^{* * *} & 0.718^{* * *} \\ 0.0778) & (0.0720) \\ 0.0996 & 0.333^{* * *} \\ (0.165) & (0.0947)\end{array}$

0.143

(0.0972)

Notes:

\begin{tabular}{llll}
\hline Observations & 802 & 628 & 632 \\
\hline
\end{tabular}

1. Data are from General Social Survey cumulative file, 1998. Estimates (1) and (2) are marginal effects from probit models evaluated at sample means. Specification (3) is an OLS with no controls or intercept, so coefficients can be interpreted as group averages.

2. Specifications (1) and (2) include dummies for region of residence, marital status, year, race, and gender, and controls for the log of income, age, age-squared, and years of completed schooling.

3. Missing values in control variables are replaced by the value 0 and a dummy for the variable being missing is included.

4. Standard errors in parentheses are adjusted for correlation within region of residence.

5. Sample size is smaller than in other tables because this question is only asked in 1998. Column 2, the omitted category is no religion. 
APPENDIX TABLE XII

Alternative outcomes

\begin{tabular}{lccccccc}
\hline & \multicolumn{3}{c}{ Military } & & \multicolumn{3}{c}{ Schools } \\
\cline { 2 - 5 } \cline { 6 - 8 } & $(1)$ & $(2)$ & $(3)$ & & $(4)$ & $(5)$ & $(6)$ \\
\hline Religious attendance & $0.0144^{* * *}$ & & $0.00783^{* * *}$ & $-0.0111^{* * *}$ & & $-0.00855^{* * *}$ \\
& $(0.00251)$ & & $(0.00205)$ & & $(0.00128)$ & & $(0.00165)$ \\
Social conservativism & & $0.238^{* * *}$ & $0.225^{* * *}$ & & $-0.0827^{* * *}$ & $-0.0657^{* * *}$ \\
& & $(0.0224)$ & $(0.0239)$ & & $(0.0113)$ & $(0.0125)$ \\
\hline $\mathrm{R}^{2}$ & 0.101 & 0.105 & 0.106 & & 0.0756 & 0.0757 & 0.0762 \\
Observations & 31022 & 30838 & 30624 & & 31828 & 31648 & 31421 \\
\hline
\end{tabular}

Notes:

1. Data are from General Social Survey cumulative file, 1972-2012. All estimates are from OLS estimations.

Standard errors in parentheses are adjusted for correlation within region of residence.

2. Outcomes are answers to questions of the type "We are faced with many problems in this country, none of which can be solved easily or inexpensively. I'm going to name some of these problems, and for each one I'd like you to tell me whether you think we're spending too much money on it, too little money, or about the right amount." The problems mentioned are "Are we spending too much, too little, or about the right amount on the military, armaments, and defense?" and "Are we spending too much, too little, or about the right amount on improving the nation's education system?", both on scales from 1-3. Outcomes are standardized.

3. All specifications include dummies for region of residence, marital status, year, race, and gender, and controls for the log of income, age, age-squared, and years of completed schooling.

4. Missing values in control variables are replaced by the value 0 and a dummy for the variable being missing is included. 


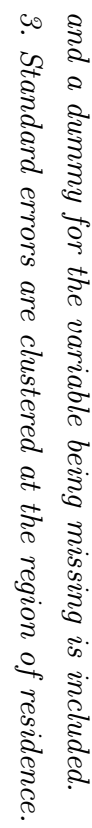

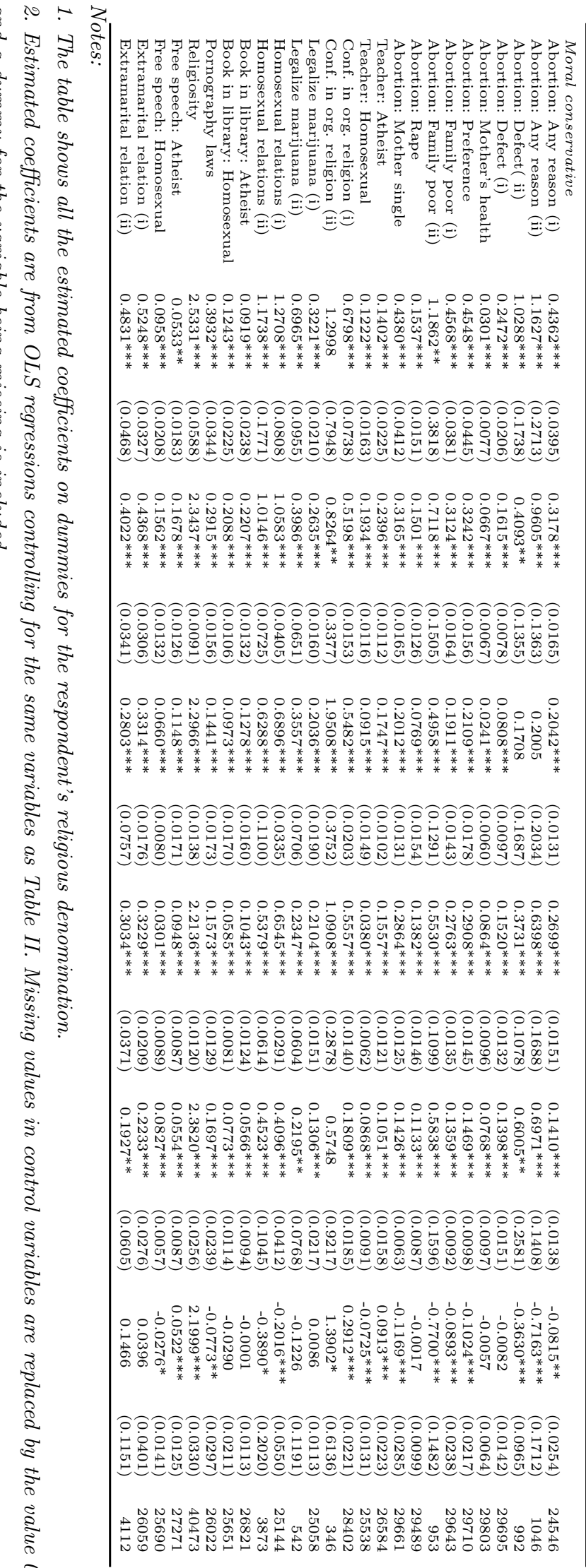

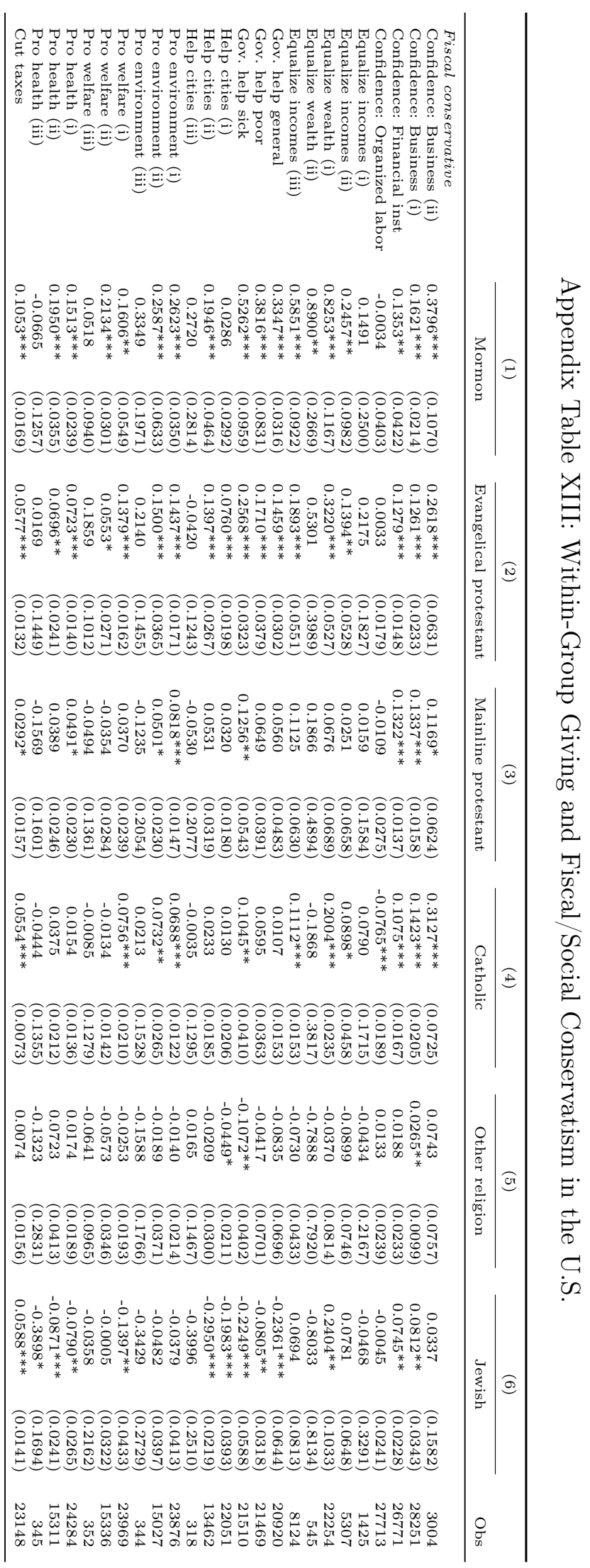


APPENDIX TABLE XIV

Within-Group Giving by Denomination in the US

\begin{tabular}{lcccccc}
\hline & \$ to Relgs & \$ to All & \%Charity to Relg & Income & \%Inc to R & N \\
\hline Mormons & 4066 & 4467 & $\mathbf{0 . 9 1}$ & 77730 & 0.052 & 26 \\
Evangelical Protestants & 908 & 1139 & $\mathbf{0 . 8 2}$ & 49755 & 0.018 & 1271 \\
Mainline Protestants & 740 & 1193 & $\mathbf{0 . 6 2}$ & 72310 & 0.010 & 997 \\
Catholics & 491 & 962 & $\mathbf{0 . 5 1}$ & 71010 & 0.007 & 1451 \\
Other & 750 & 1504 & $\mathbf{0 . 5 0}$ & 49780 & 0.015 & 938 \\
Jewish & 1127 & 2791 & $\mathbf{0 . 4 0}$ & 125160 & 0.009 & 142 \\
None & 221 & 553 & $\mathbf{0 . 4 0}$ & 54360 & 0.004 & 663 \\
\hline
\end{tabular}

Notes:

1. Data are from the 2001 Center on Philanthropy Panel Study portion of the Current Population Surveys. Summary statistics by denomination are reported in Smith (2004). 
APPENDIX TABLE XV

Detailed estimation results on Welfare attitudes around the World

\begin{tabular}{|c|c|c|c|c|c|c|c|c|c|c|}
\hline \multirow{2}{*}{$\frac{\text { Country }}{\text { Albania }}$} & To & & Wa & 2 & Wav & & Wav & & Wav & \\
\hline & $.077^{* * *}$ & $(.027)$ & & & $.085^{* *}$ & $(.04)$ & .035 & $(.038)$ & & \\
\hline Algeria & -.028 & $(.029)$ & & & & & -.028 & $(.029)$ & & \\
\hline Andorra & .02 & $(.037)$ & & & & & & & .02 & $(.037)$ \\
\hline Azerbaijan & $.1 * * *$ & $(.034)$ & & & $.1 * * *$ & $(.034)$ & & & & \\
\hline Argentina & $-.091^{* * *}$ & $(.02)$ & & & $-.095 * * *$ & $(.036)$ & -.044 & $(.035)$ & & \\
\hline Australia & -.014 & $(.018)$ & & & -.0064 & $(.023)$ & & & -.022 & $(.03)$ \\
\hline Bangladesh & .015 & $(.029)$ & & & -.026 & $(.059)$ & $-.063 *$ & $(.037)$ & & \\
\hline Armenia & -.024 & $(.029)$ & & & -.024 & $(.029)$ & & & & \\
\hline Brazil & .021 & $(.022)$ & .041 & $(.034)$ & -.036 & $(.055)$ & & & -.04 & $(.031)$ \\
\hline Bulgaria & -.00074 & $(.029)$ & & & $-.081 * *$ & $(.041)$ & & & .067 & $(.042)$ \\
\hline Belarus & $.2 * * *$ & $(.025)$ & & & $.15^{* * *}$ & $(.029)$ & & & & \\
\hline Canada & $-.039 * *$ & $(.016)$ & & & & & -.028 & $(.023)$ & $-.045^{* *}$ & $(.021)$ \\
\hline Chile & $-.053 * * *$ & $(.017)$ & & & $-.095 * * *$ & $(.035)$ & -.014 & $(.03)$ & -.043 & $(.034)$ \\
\hline China & $.074^{*}$ & $(.04)$ & & & & & -.012 & $(.079)$ & .0053 & $(.062)$ \\
\hline Taiwan & .03 & $(.027)$ & & & .0052 & $(.041)$ & & & .049 & $(.036)$ \\
\hline Colombia & $-.032 *$ & $(.018)$ & & & -.0042 & $(.025)$ & & & $-.056 * *$ & $(.026)$ \\
\hline Cyprus & $-.069^{*}$ & $(.039)$ & & & & & & & $-.069^{*}$ & $(.039)$ \\
\hline Czech Republic & $.058^{*}$ & $(.03)$ & & & .022 & $(.036)$ & & & & \\
\hline Dominican Republic & $.14^{* *}$ & $(.068)$ & & & $.14^{* *}$ & $(.068)$ & & & & \\
\hline El Salvador & .012 & $(.043)$ & & & .012 & $(.043)$ & & & & \\
\hline Ethiopia & .041 & $(.034)$ & & & & & & & .041 & $(.034)$ \\
\hline Estonia & $.081^{*}$ & $(.044)$ & & & $.081 *$ & $(.044)$ & & & & \\
\hline Finland & .026 & $(.029)$ & & & .068 & $(.047)$ & & & -.0017 & $(.036)$ \\
\hline France & $-.12 * * *$ & $(.04)$ & & & & & & & $-.12 * * *$ & $(.04)$ \\
\hline Georgia & .0026 & $(.022)$ & & & -.012 & $(.032)$ & & & -.00087 & $(.032)$ \\
\hline Ghana & .037 & $(.047)$ & & & & & & & .037 & $(.047)$ \\
\hline Guatemala & -.014 & $(.054)$ & & & & & & & -.014 & $(.054)$ \\
\hline Hong Kong & -.0059 & $(.024)$ & & & & & & & -.0059 & $(.024)$ \\
\hline India & $-.078^{* * *}$ & $(.02)$ & .019 & $(.027)$ & $-.091 * *$ & $(.043)$ & $-.16^{* * *}$ & $(.044)$ & $.088^{* *}$ & $(.042)$ \\
\hline Indonesia & $-.087^{* * *}$ & $(.031)$ & & & & & -.058 & $(.057)$ & $-.099^{* * *}$ & $(.036)$ \\
\hline Iran & .00048 & (.019) & & & & & .05 & $(.037)$ & .027 & $(.022)$ \\
\hline Iraq & $.026^{* *}$ & $(.013)$ & & & & & $.043^{* *}$ & $(.019)$ & .0081 & $(.016)$ \\
\hline Italy & .02 & $(.038)$ & & & & & & & .02 & $(.038)$ \\
\hline Japan & $-.066^{* * *}$ & $(.023)$ & & & & & $-.13^{* * *}$ & $(.043)$ & $-.092^{* *}$ & $(.045)$ \\
\hline Jordan & $.088^{* * *}$ & $(.02)$ & & & & & $.049^{*}$ & $(.026)$ & & \\
\hline South Korea & $-.092^{* * *}$ & (.017) & -.025 & $(.049)$ & $.064 * *$ & $(.028)$ & $.061 * *$ & $(.025)$ & .022 & $(.026)$ \\
\hline Kyrgyzstan & .016 & $(.04)$ & & & & & .016 & $(.04)$ & & \\
\hline Latvia & $.066^{*}$ & $(.037)$ & & & $.066^{*}$ & $(.037)$ & & & & \\
\hline Lithuania & .069 & $(.042)$ & & & .069 & $(.042)$ & & & & \\
\hline Mali & .0084 & $(.039)$ & & & & & & & .0084 & $(.039)$ \\
\hline Mexico & .0076 & $(.017)$ & & & .036 & $(.026)$ & -.014 & $(.048)$ & .014 & $(.039)$ \\
\hline Moldova & $.12 * * *$ & $(.026)$ & & & $.19 * * *$ & $(.044)$ & .016 & $(.047)$ & $.17^{* * *}$ & $(.045)$ \\
\hline Morocco & $.062^{* * *}$ & $(.022)$ & & & & & $.062^{* * *}$ & $(.022)$ & & \\
\hline Netherlands & $-.091 * * *$ & $(.033)$ & & & & & & & $-.091 * * *$ & $(.033)$ \\
\hline New Zealand & $-.051 * *$ & $(.025)$ & & & $-.061^{*}$ & $(.033)$ & & & -.046 & $(.037)$ \\
\hline Nigeria & .034 & $(.028)$ & -.072 & $(.055)$ & $.11 * * *$ & $(.043)$ & -.07 & $(.051)$ & & \\
\hline Norway & -.027 & $(.025)$ & & & .034 & $(.034)$ & & & $-.09 * *$ & $(.036)$ \\
\hline Pakistan & $.18^{* * *}$ & $(.042)$ & & & & & $.18^{* * *}$ & $(.042)$ & & \\
\hline Peru & .0011 & $(.024)$ & & & .0058 & $(.045)$ & -.011 & $(.043)$ & .0054 & $(.039)$ \\
\hline Philippines & -.019 & $(.038)$ & & & & & -.028 & $(.046)$ & & \\
\hline Poland & $.065^{*}$ & $(.036)$ & & & $.11^{* *}$ & $(.049)$ & & & .0074 & $(.052)$ \\
\hline Puerto Rico & -.0088 & $(.031)$ & & & -.00096 & $(.04)$ & .00076 & $(.05)$ & & \\
\hline Romania & .018 & $(.028)$ & & & $.082^{*}$ & $(.043)$ & & & -.025 & $(.037)$ \\
\hline Russian Federation & $.12 * * *$ & $(.021)$ & & & .033 & $(.033)$ & & & .0084 & $(.033)$ \\
\hline Rwanda & -.099 & $(.06)$ & & & & & & & -.099 & $(.06)$ \\
\hline Saudi Arabia & $.053^{*}$ & $(.028)$ & & & & & $.053^{*}$ & $(.028)$ & & \\
\hline Singapore & $.17^{* * *}$ & $(.03)$ & & & & & $.17^{* * *}$ & $(.03)$ & & \\
\hline Slovakia & $.066^{* *}$ & $(.027)$ & & & $.059^{* *}$ & $(.03)$ & & & & \\
\hline Viet Nam & $.061^{* *}$ & $(.027)$ & & & & & $-.09 *$ & $(.046)$ & $.13^{* * *}$ & $(.034)$ \\
\hline Slovenia & $.051^{* *}$ & $(.026)$ & & & & & & & .033 & $(.037)$ \\
\hline South Africa & $-.028 *$ & $(.014)$ & & & $-.049 *$ & $(.027)$ & .0086 & $(.025)$ & $-.047^{* *}$ & $(.024)$ \\
\hline Zimbabwe & -.0019 & $(.046)$ & & & & & -.0019 & $(.046)$ & & \\
\hline Spain & -.022 & $(.015)$ & & & .016 & $(.03)$ & -.000014 & $(.027)$ & -.011 & $(.028)$ \\
\hline Sweden & -.014 & $(.025)$ & & & -.0043 & $(.035)$ & -.018 & $(.039)$ & -.016 & $(.04)$ \\
\hline Switzerland & -.037 & $(.024)$ & & & .0041 & $(.034)$ & & & -.048 & $(.032)$ \\
\hline Thailand & $.12 * * *$ & $(.037)$ & & & & & & & $.12^{* * *}$ & $(.037)$ \\
\hline Trinidad and Tobago & .06 & $(.048)$ & & & & & & & .06 & $(.048)$ \\
\hline Turkey & $-.025^{*}$ & $(.014)$ & $-.12^{* * *}$ & $(.038)$ & $.18^{* * *}$ & $(.032)$ & $-.075 * * *$ & $(.019)$ & -.031 & $(.029)$ \\
\hline Uganda & -.092 & $(.068)$ & & & & & -.092 & $(.068)$ & & \\
\hline Ukraine & .027 & $(.021)$ & & & $.071^{* * *}$ & $(.024)$ & & & -.048 & $(.041)$ \\
\hline Macedonia & $.054^{*}$ & $(.032)$ & & & $.1 * *$ & $(.046)$ & -.019 & $(.045)$ & & \\
\hline Egypt & $-.02 *$ & $(.012)$ & & & & & .0052 & $(.019)$ & $-.039 * * *$ & $(.014)$ \\
\hline Great Britain & .028 & $(.034)$ & & & & & & & .028 & $(.034)$ \\
\hline Tanzania & -.025 & $(.055)$ & & & & & -.025 & $(.055)$ & & \\
\hline United States & $-.095 * * *$ & $(.017)$ & & & $-.063 * *$ & $(.028)$ & -.052 & $(.032)$ & $-.11 * * *$ & $(.028)$ \\
\hline Burkina Faso & $.06^{*}$ & $(.036)$ & & & & & & & $.06^{*}$ & $(.036)$ \\
\hline Uruguay & $-.069 * *$ & $(.03)$ & & & -.019 & $(.038)$ & & & -.058 & $(.05)$ \\
\hline Venezuela & -.02 & $(.031)$ & & & .015 & $(.045)$ & -.055 & $(.042)$ & & \\
\hline Zambia & $-.17 * * *$ & $(.04)$ & & & & & & & $-.17 * * *$ & $(.04)$ \\
\hline Germany West & -.0045 & $(.025)$ & & & -.023 & $(.034)$ & & & -.03 & $(.036)$ \\
\hline Germany East & $-.057^{*}$ & $(.03)$ & & & -.071 & $(.043)$ & & & -.041 & $(.042)$ \\
\hline Serbia & .015 & $(.024)$ & & & $.077^{* *}$ & $(.038)$ & $.14^{* * *}$ & $(.042)$ & -.035 & $(.042)$ \\
\hline Montenegro & $.18^{* * *}$ & $(.039)$ & & & $-.16^{*}$ & $(.089)$ & $.26^{* * *}$ & $(.044)$ & & \\
\hline SrpSka - Serbian Rep & $.095^{*}$ & $(.054)$ & & & .014 & $(.059)$ & $.24 * * *$ & $(.087)$ & & \\
\hline Bosnia Federation & $-.056 * *$ & $(.028)$ & & & -.031 & $(.039)$ & $-.082^{* *}$ & $(.04)$ & & \\
\hline
\end{tabular}

Notes:

1. Data are from World Values Survey cumulative file, waves 2-5. Standard errors in parentheses are adjusted for correlation within country of residence.

54

2. All specifications include dummies for country of residence, survey wave, gender, and category of educational attainment and controls for the income, age, and age ${ }^{2}$.

3. Missing values in control variables are replaced by the value 0 and a dummy for the variable being missing is 


\begin{tabular}{lccc}
\hline & \multicolumn{2}{c}{ Attendance } & $\mathrm{N}$ \\
\cline { 2 - 3 } Respect and love for parents & $0.012^{* * *}$ & $(0.001)$ & 152872 \\
Parents responsibilities to their children & $0.008^{* * *}$ & $(0.001)$ & 152336 \\
Important child qualities: good manners & 0.001 & $(0.001)$ & 123876 \\
Important child qualities: religious faith & $0.043^{* * *}$ & $(0.003)$ & 232732 \\
Important child qualities: obedience & $0.006^{* * *}$ & $(0.001)$ & 234867 \\
Important child qualities: independence & $-0.010^{* * *}$ & $(0.001)$ & 234867 \\
Important child qualities: imagination & $-0.007^{* * *}$ & $(0.001)$ & 232569 \\
Important child qualities: tolerance and respect for other people & $-0.002^{* * *}$ & $(0.001)$ & 234867 \\
What children should learn 1 & $0.028^{* * *}$ & $(0.002)$ & 69072 \\
Jobs scarce: Men should have more right to a job than women & $0.007^{* * *}$ & $(0.001)$ & 219238 \\
A woman has to have children to be fulfilled & $0.008^{* * *}$ & $(0.001)$ & 156126 \\
Marriage is an out-dated institution & 0.000 & $(0.000)$ & 205297 \\
Enjoy sexual freedom & $-0.013^{* * * *}$ & $(0.002)$ & 87478 \\
Woman as a single parent & $-0.016^{* * * *}$ & $(0.002)$ & 216423 \\
Statement: good and evil & $0.021^{* * *}$ & $(0.002)$ & 128720 \\
Justifiable: homosexuality & $0.014^{* * *}$ & $(0.001)$ & 205856 \\
Justifiable: abortion & $0.024^{* * *}$ & $(0.002)$ & 216178 \\
Justifiable: divorce & $0.015^{* * *}$ & $(0.001)$ & 218534 \\
Justifiable: euthanasia & $0.021^{* * *}$ & $(0.002)$ & 201121 \\
\hline
\end{tabular}

Notes:

1. Data are from World Values Survey cumulative file, waves 2-5. Standard errors in parentheses are adjusted for correlation within country of residence.

2. All specifications include dummies for country of residence, survey wave, gender, and category of educational attainment and controls for income, age, and age $e^{2}$.

3. Missing values in control variables are replaced by the value 0 and a dummy for the variable being missing is included. 
APPENDIX TABLE XVII

Countries With AND Without a STATE CHURCH

\begin{tabular}{|c|c|}
\hline Without state church & With state church \\
\hline Albania & Armenian Apostolic Church \\
\hline Australia & Armenia \\
\hline Brazil & Buddhist \\
\hline Canada & Thailand \\
\hline Chile & Jew \\
\hline China & Israel \\
\hline Taiwan & Muslim \\
\hline Cyprus & Algeria \\
\hline Czech Republic & Azerbaijan \\
\hline Ethiopia & Bangladesh \\
\hline Estonia & Iran \\
\hline France & Iraq \\
\hline Ghana & Jordan \\
\hline Hong Kong & Kyrgyzstan \\
\hline Hungary & Malaysia \\
\hline India & Morocco \\
\hline Indonesia & Pakistan \\
\hline Japan & Saudi Arabia \\
\hline South Korea & Egypt \\
\hline Latvia & Orthodox \\
\hline Lithuania & Bulgaria \\
\hline Mali & Belarus \\
\hline Mexico & Georgia \\
\hline Netherlands & Moldova \\
\hline New Zealand & Ukraine \\
\hline Nigeria & Macedonia \\
\hline Philippines & Protestant \\
\hline Poland & Finland \\
\hline Puerto Rico & Norway \\
\hline Romania & Great Britain \\
\hline Russian Federation & Roman Catholic \\
\hline Rwanda & Andorra \\
\hline Singapore & Argentina \\
\hline Slovakia & Colombia \\
\hline Viet Nam & Croatia \\
\hline Slovenia & Dominican Republic \\
\hline South Africa & El Salvador \\
\hline Zimbabwe & Guatemala \\
\hline Switzerland & Italy \\
\hline Trinidad and Tobago & Peru \\
\hline Turkey & Spain \\
\hline Uganda & Venezuela \\
\hline Tanzania & The Church of Sweden \\
\hline United States & Sweden \\
\hline \multicolumn{2}{|l|}{ Burkina Faso } \\
\hline \multicolumn{2}{|l|}{ Uruguay } \\
\hline \multicolumn{2}{|l|}{ Zambia } \\
\hline \multicolumn{2}{|l|}{ Germany West } \\
\hline \multicolumn{2}{|l|}{ Germany East } \\
\hline \multicolumn{2}{|l|}{ Serbia } \\
\hline \multicolumn{2}{|l|}{ Montenegro } \\
\hline \multicolumn{2}{|l|}{ SrpSka - Serbian Republic of Bosnia } \\
\hline Bosnia Federation & \\
\hline
\end{tabular}

Notes:

1. Coding of state church status is taken from Barro and McCleary (2005), which is based on Barrett (1982) and Barrett et al. (2001). 


\title{
Appendix Table XVIII: US Supreme Court Decisions on Church-State Separation
}

\author{
1940 Minersville School District v. Gobitis (1940) \\ none In an 8-1 Court Decision, the Court ruled that a school district's interest in creating national unity \\ was sufficient to allow them to require students to salute the flag. \\ 1943 West Virginia State Board of Education v. Barnette (1943) \\ none The Court ruled 8-1 that a school district violated the rights of students by forcing them to salute the \\ American flag. \\ 1947 Everson v. Board of Education (1947) \\ decrease Supreme Court decision finding that a New Jersey law providing for reimbursement to parents of \\ parochial school students for transportation costs on public busses is constitutional. \\ 1948 McCollum v. Board of Education (1948) \\ increase By a 6-1 vote the Supreme Court agreed with Mrs. McCollum, an atheist mother, and disallowed the \\ practice of having religious education to take place in public school classrooms during the school day. \\ $1962 \quad$ Engel v. Vitale (1962) \\ increase The Court ruled 7 to 1 that it was unconstitutional for a government agency like a school or government \\ agents like public school employees to require students to recite prayers.
}

1963 Abington Township School District v. Schempp (1963)

increase The Court ruled 8-1 against requiring the recitation of Bible verses and the Lord's Prayer.

1968 Board of Education v. Allen (1968)

decrease Supreme Court decision finding that a New York Law requiring public school districts to purchase text books for private schools, including parochial schools, is permissible and not a violation of the Establishment Clause.

1968 Epperson v. Arkansas (1968)

increase The Court found that an Arkansas law prohibiting the teaching of evolution is impermissible because it violates the Establishment Clause and prohibits the free exercise of religion.

1971 Lemon v. Kurtzman (1971)

increase On June 28th, 1971, the Court unanimously (7-0) determined that the direct government assistance to religious schools was unconstitutional.

1972 Wisconsin v. Yoder (1972)

none On May 15th 1972 the Court ruled 6 to 1 that the compulsory education law in Winconsin did indeed violate the Free Exercise Clause for Amish parents.

1973 Committee for Public Education v. Nyquist (1973)

increase The Court found all three sections of a New York law providing, among other things, tax deductions and reimbursements for children in parochial schools, unconstitutional. Each of the three parts of the law had the primary effect of furthering religion.

1975 Meek v. Pittenger (1975)

increase Supreme Court decision invalidating most of two Pennsylvania laws providing for instructional materials and equipment to religious schools because most of that aid could be easily diverted to religious purposes.

1977 Wolman v. Walter (1977)

increase The Court allowed Ohio to provide standardized tests, therapeutic and diagnostic services to non-public school children. However, the state was not permitted to offer educational materials or subsidize class field trips.

1980 Stone v. Graham (1980) 
increase The Court ruled that a Kentucky law requiring the posting of the Ten Commandments in each public school classroom in the state to be unconstituional.

$1981 \quad$ Segraves v. California (1981)

increase A California judge ruled that teaching evolution in public school science classes does not infringe upon the rights of any students or parents to the free exercise of their religion, even if they sincerely believe that evolution is contrary to their religious beliefs.

$1981 \quad$ McClean v. Arkansas (1981)

increase The Court found that Arkasas' "blanced treatment" law mandating equal treatment of creation science with evolution was unconstitutional.

$1983 \quad$ Mueller v. Allen (1983)

decrease The Supreme Court rules 5-4 that a Minnesota law allowing parents to make tax deductions for expenses incurred through things like textbooks and other supplies at private schools is constitutional, even thought most of the benefit goes to religious and not secular schools.

1985 Aguilar v. Felton (1985)

increase In a 5-4 Court Decision in 1985, the Court overturned New York City's program of paying the salaries of public employees who provided any remedial assistance to low-income students in parochial school environments.

1985 Grand Rapids School District v. Ball (1985)

increase Grand Rapids School District offered two programs conducted in leased private school classrooms: one taught during the regular school day by public school teachers and the other taught after regular school hours by part-time teachers. Both were found unconstitional.

$1985 \quad$ Wallace v. Jaffree (1985)

increase The Court found that an Alabma law requiring that each school day begin with a one minute period of "silent meditation or voluntary prayer" was unconstitional.

1987 Edwards v. Aguillard (1987)

increase In a 7-2 Court Decision, the Court invalidated Louisiana's "Creationism Act" because it violated the Establishment Clause.

$1989 \quad$ Board of Education of Kiryas Joel Village School v. Grumet (1989)

increase The Court found that a school district boundary was unconstitutionally drawn to deliberately aid a particular religious group.

$1990 \quad$ Webster v. New Lenox (1990)

increase Seventh Circuit Court of Appeals ruled that school boards have the right to prohibit teaching creationism because such lessons would constitute religious advocacy and, hence, such restrictions do not constitute an infringement on a teacher's free speech rights.

$1992 \quad$ Lee v. Weisman (1992)

increase On June 24th 1992, the Court ruled in a 5-4 Court Decision that the graduation prayer during school graduation violated the Establishment Clause.

1992 Jones v. Clear Creek (1992)

decrease The Fifth Circuit Court ruled that it was not unconstitutional for a school to allow graduating seniors to vote on whether or not there would prayers during graduation ceremonies.

1993 Zobrest v. Catalina Foothills School District (1993)

decrease In 1993, the Court decided 5-4 to require a school district to offer a student in a private religious school the sign language interpreter he needed.

1994 Peloza v. Capistrano (1994)

increase Ninth Circuit Court of Appeals decision that a teacher does not have a right to teach creationism in a biology class, that "evolutionism" is not a religion or world view, and that the government can restrict the speech of employees while they are on the job.

1994 Brown v. Woodland Joint Unified School District (1994) 
none

1995

increase

1997

decrease

1998

increase

1999

increase

1999

increase

1999

increase

2000

decrease The Supreme Court ruled that official, student-led prayers before a school football game violated the separation of church and state.

$2000 \quad$ Mitchell v. Helms (2000)

increase Supreme Court decision allowing for educational materials and equipment to be given to religious schools, even if such equipment could be and is diverted for religious purposes - so long as this aid is granted to any religious or private school in an even-handed manner.

2001 LeVake v. Independent School District (2001)

increase A federal district court finds that a school may remove a teacher from teaching a biology class when that teacher, a creationist, cannot adequately teach evolution.

2002 FFRF v. Rhea County Board of Education (2002)

increase A federal district court decides that a public school cannot have students from the local Bryan College come in to teach Bible classes.

2002 Zelman v. Simmons (2002)

decrease The Supreme Court rules 5-4 that a Cleveland, Ohio, program which spends large amounts of public money on subsidizing education at religious schools is constitutional.

Notes:

1. Data from About.com "Supreme Court Decisions-Religion in Schools", which document US Supreme Court activity (where the Supreme Court either made a decision or let stand a lower court decision) and are drawn from Hall (1999) and Alley (1988; 1999). 
Appendix Figure 1: Welfare attitudes and Fundamentalism in the U.S. - Principal components

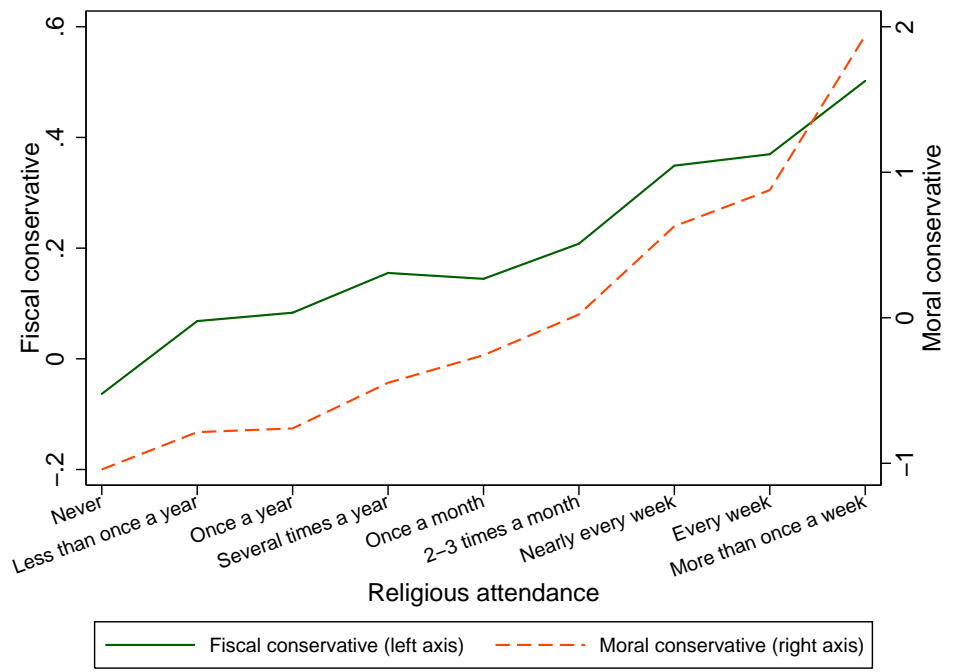

Notes: Data are from General Social Survey cumulative file, 1972-2012. Fiscal and moral conservative are the predicted first factors from principal component analyses of the full data employed in Table I. Missing values are imputed the value 0 in the standardized variables. Sample is the White population 